AL.2.2008-13

c. 2

A REVIEW OF INDICATORS OF WETLAND HEALTH AND FUNCTION IN ALBERTA'S PRAIRIE, ASPEN PARKLAND AND BOREAL DRY MIXEDWOOD REGIONS
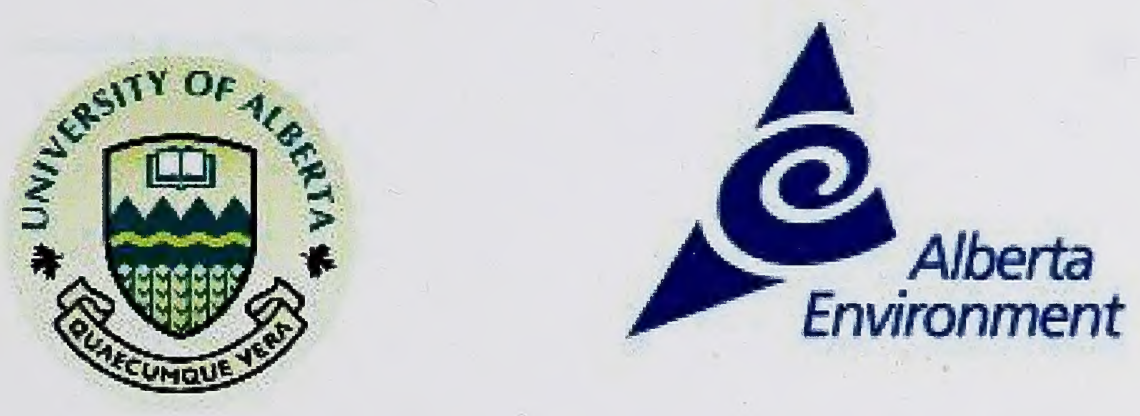


\title{
A REVIEW OF INDICATORS OF WETLAND HEALTH AND FUNCTION IN ALBERTA'S PRAIRIE, ASPEN PARKLAND AND BOREAL DRY MIXEDWOOD REGIONS
}

\author{
Prepared for:
}

The Water Research Users Group, Alberta Environment

Prepared by:

Heather E. Wray and Suzanne E. Bayley University of Alberta, Edmonton, $A B$

March, 2006 
ISBN No. 978-0-7785-6768-4 (Printed Edition)

ISBN No. 978-0-7785-6769-1 (On-line Edition)

Web Site: http://environment.gov.ab.ca/info/home.asp

Any comments, questions, or suggestions regarding the content of this document may be directed to:

Environmental Policy Branch

Alberta Environment

$4^{\text {th }}$ Floor, Oxbridge Place

$9820-106^{\text {th }}$ Street

Edmonton, Alberta T5K 2J6

Phone: (780) 427-7533

Fax: (780) 422-4192

Additional copies of this document may be obtained by contacting:

Information Centre

Alberta Environment

Main Floor, Great West Life Building

$9920-108^{\text {th }}$ Street

Edmonton, Alberta T5K 2M4

Phone: (780) 944-0313

Fax: (780) 427-4407

Email: env.infocent@gov.ab.ca 


\section{SUMMARY}

Wetlands cover approximately $21 \%$ of the land area of the province of Alberta (National Wetlands Working Group 1988) and are unique ecosystems that provide several valuable ecological and economic functions including water storage and flood attenuation, erosion control, water quality improvement and habitat for various plant and animal species (Ducks Unlimited Canada 2004). Many wetlands in Alberta, especially in the southern half of the province, have been negatively impacted by anthropogenic disturbances (Turner et al. 1987) which in turn affect the wetland health and function. The purpose of this report is to conduct a review of the primary literature on Alberta wetlands and identify potential indicators of health of wetland ecosystems in Alberta, specifically in the prairie, aspen parkland and boreal dry mixedwood regions.

Despite the large amount of research on various wetlands in North America, information on the general ecology and characteristics of wetlands in Alberta is limited, especially in the aspen parkland and boreal dry mixedwood ecozones of the province. Research on prairie wetlands is also limited within the province, however extensive research has been done in the prairie pothole region of the United States and many of these wetlands are similar to Alberta's prairie wetlands.

Information on wetland loss and destruction, extent of disturbance to wetlands and the impacts of these disturbances on wetland health and function, are lacking or minimal within the province of Alberta. While there are some studies of wetland loss in selected areas of the province, there is no complete regional or province-wide mapping or survey of wetlands in Alberta at this time, nor is there a wide-scale assessment of disturbance to wetlands. Compared to other regions of North America very few wetland studies have been conducted in the prairie, parkland and boreal dry mixedwood regions of Alberta and most studies that have been conducted were performed in the last decade (Appendix 1). Without this comprehensive baseline information it is difficult to make inferences about good potential indicators of wetland health in the province, especially given the wide range of natural variation within and among wetlands (US EPA 2002c, d). Based on the scientific literature from studies on Alberta wetlands, as well as other North American wetlands, there does not seem to be any one indicator or class of indicators which will be the most useful to use singly to assess wetland health and function.

Potentially useful indicators of wetland health in the prairie region of Alberta include water chemistry parameters such as nutrients $(\mathrm{N}$ and $\mathrm{P})$ and turbidity as well as physical characteristics of the riparian buffer areas surrounding wetlands. Potential biological indicators of wetland health in Alberta's prairie region include invertebrate diversity, zooplankton species richness, macrophyte floristic quality and presence of native vs. introduced species, abundance of submersed aquatic vegetation (SAV), presence of monotypic cattail stands and algal biomass and community composition.

In the aspen parkland region of Alberta, potentially good indicators of wetland health include water chemistry parameters such as total phosphorus (TP), total dissolved nitrogen 
(TDN) and calcium concentrations as well as riparian buffer characteristics and biological indicators such as abundance of benthic macroinvertebrates and abundance and breeding activity of waterfowl species. Vegetative and algal characteristics may also be useful.

In the boreal dry mixedwood region of the province, potential indicators were very difficult to identify due to lack of baseline data in this region. Suggestions include assessing extent of agricultural or forested areas in the watershed and obvious physical disturbance to the surrounding watersheds such as fragmentation as indicators of a disturbed wetland. There may be potential for any of the indicators used in prairie or aspen parkland systems as well as use of waterfowl abundance as biological indicators of wetland health in this region, however data are lacking.

A study measuring these potential indicators in wetlands of Alberta's prairie, aspen parkland and boreal dry mixedwood region is recommended in wetlands across a range of disturbance. Good indicators should respond in a predictable and measurable manner along a disturbance gradient. Despite the fact that most wetlands in the prairie and aspen parkland regions have already been anthropogenically disturbed, a range of disturbances still exists, from minimally impacted to heavily impacted. Wetlands should further be divided into classes for indicator assessment since natural variation will exist between different types of wetlands (NWWG 1998). It is further recommended that several indicators within a wetland system be combined to form a multimetric index of the overall health or condition of a wetland site.

While there are little data available in the three regions of Alberta, based on our review of the broader literature, we expect that a useful initial approach would focus on determining an index of biotic integrity (IBI) using macrophytic vegetation (abundance and diversity), macroinvertebrates, and nutrients in marshes, the dominant wetland class in much of the white zone of Alberta. 


\section{TABLE OF CONTENTS}

SUMMARY ii

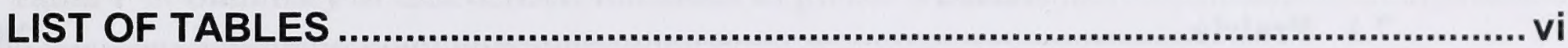

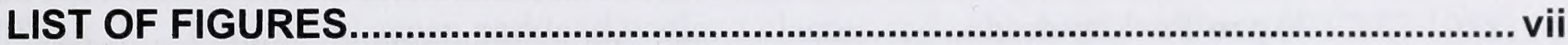

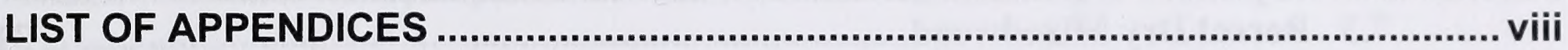

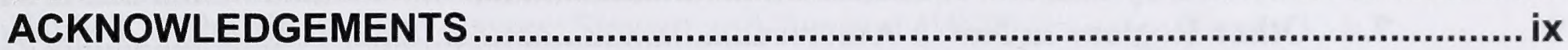

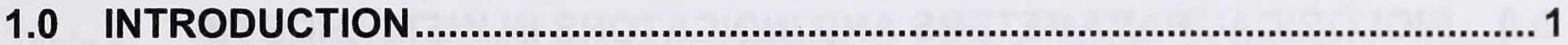

2.0 GENERAL FUNCTIONS AND VALUES OF FRESHWATER WETLANDS .......... 2

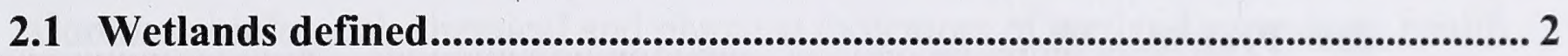

2.2 The Canadian Wetland Classification System ........................................................ 2

2.3 The US Wetland Classification System ...................................................................... 3

2.4 Global and National Importance of Wetlands ......................................................... 3

2.5 Physical Functions of Wetlands ..................................................................................... 4

2.6 Chemical Functions of Wetlands .................................................................................. 4

2.7 Biological Functions of Wetlands ............................................................................. 5

3.0 CHARACTERISTICS AND FUNCTIONS OF ALBERTA WETLANDS .................6

3.1 The Prairie Region of Alberta ...................................................................................... 6

3.1.1 Classes of Wetlands Present - The Canadian Wetland Classification

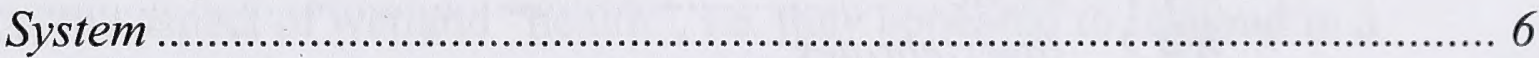

3.1.2 Classes of Wetlands Present - Stewart and Kantrud (1971) classification 9

3.2 The Aspen Parkland Region of Alberta ..................................................................... 10

3.2.1 Classes of Wetlands Present ............................................................. 11

3.3 The Boreal Mixedwood Region of Alberta ........................................................ 11

3.3.1 Classes of Wetlands Present ………………................................... 11

3.4 Functions and values of Alberta Wetlands........................................................... 12

3.4.1 Biological Functions...................................................................... 14

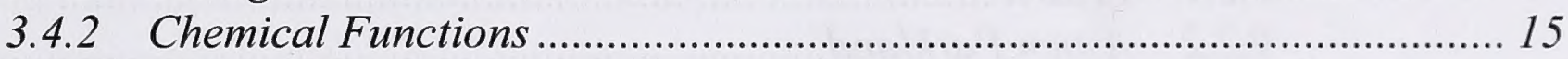

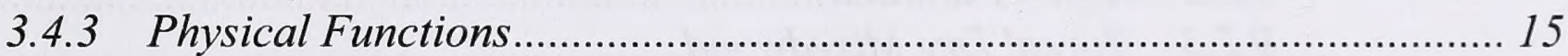

4.0 DEFINING INDICATORS OF HEALTHY WETLAND ECOSYSTEMS ................17

5.0 RELATIONSHIPS BETWEEN WETLAND FUNCTIONS AND INDICATORS..... 19

5.1 Physical Indicators........................................................................................................... 19

5.2 Chemical Indicators............................................................................................. 19

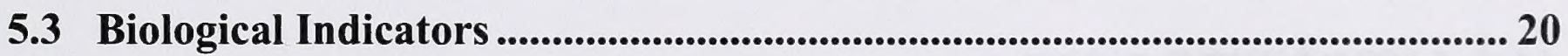

5.4 Interactions of Indicators ....................................................................................... 21

6.0 DISTURBANCES AFFECTING WETLANDS IN ALBERTA'S PRAIRIE, ASPEN PARKLAND AND BOREAL DRY MIXEDWOOD REGIONS.............................23

6.1 Loss and Destruction of Wetlands...................................................................... 24

6.2 Direct Disturbances to Wetlands in Alberta ..................................................... 25

6.3 Indirect Disturbances to Wetlands in Alberta ...................................................... 26

6.4 Climate Change ......................................................................................................... 27

A Review of indicators of wetland health and function in Alberta's prairie, aspen parkland and boreal iv dry mixed wood regions 
7.0 PHYSICAL AND CHEMICAL PARAMETERS AND INDICATORS IN WETLANDS OF ALBERTA'S PRAIRIE, ASPEN PARKLAND AND BOREAL DRY MIXEDWOOD ECOZONES

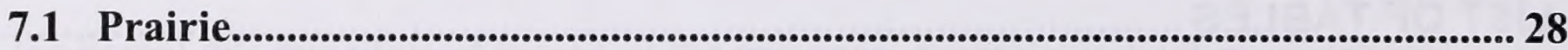

7.2 Aspen Parkland .................................................................................................................. 30

7.3 Boreal Dry Mixedwood................................................................................................. 31

7.4 Other Regions in North America.............................................................................. 31

8.0 BIOLOGICAL PARAMETERS AND INDICATORS IN WETLANDS OF ALBERTA'S PRAIRIE, ASPEN PARKLAND AND BOREAL DRY MIXEDWOOD ECOZONES

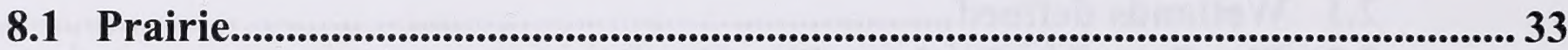

8.1.1 Invertebrates as Indicators in Prairie Wetlands................................... 33

8.1.2 Emergent and Submersed Aquatic Macrophytes as Indicators in Prairie

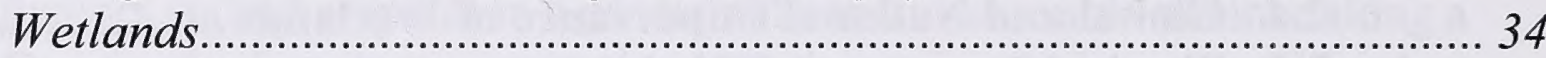

8.1.3 Waterfowl as Indicators in Prairie Wetlands ......................................... 35

8.1.4 Fish and Amphibian Communities as Indicators in Prairie Wetlands ..... 36

8.2 Aspen Parkland .................................................................................................................... 36

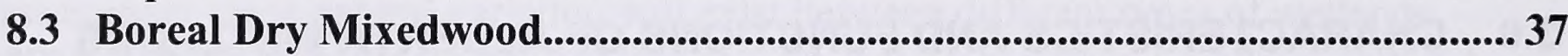

8.4 Studies Based in Other Regions of North America and Potential Biological Indicators of Wetland Health in Alberta .............................................................. 39

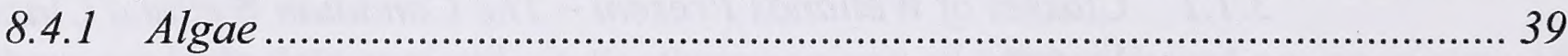

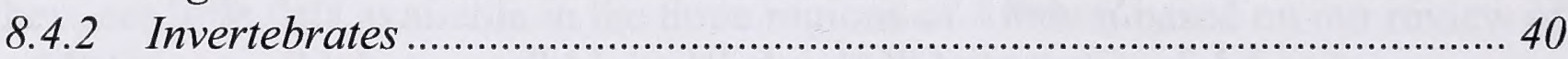

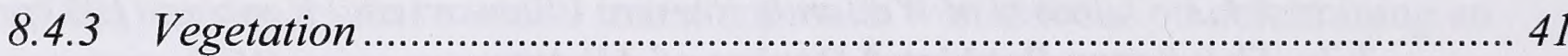

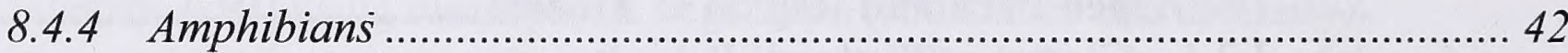

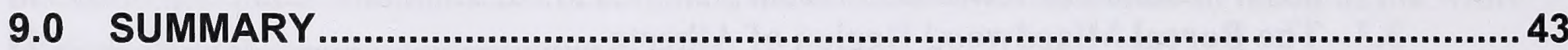

9.1 Issues to Consider When Developing Indicators.................................................... 44

9.2 Potential Physical and Chemical Indicators........................................................ 45

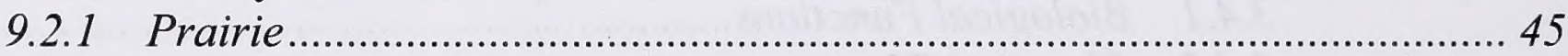

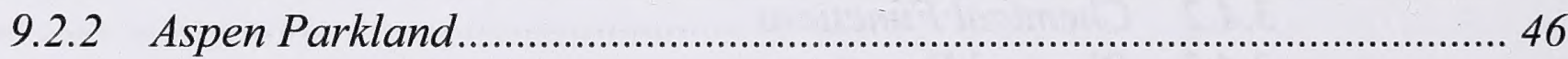

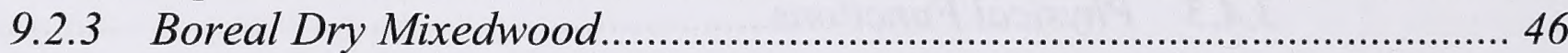

9.3 Potential Biological Indicators........................................................................... 46

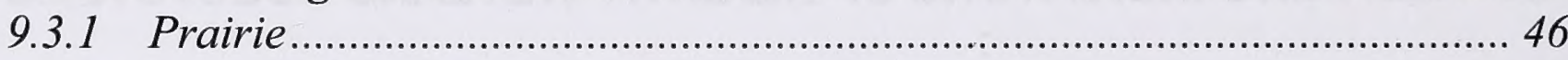

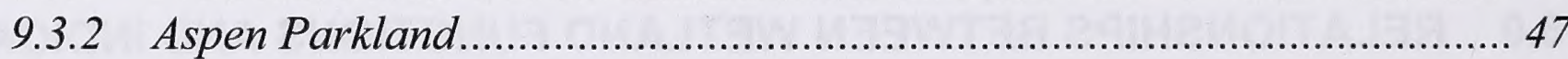

9.3.3 Boreal Dry Mixedwood.............................................................. 48

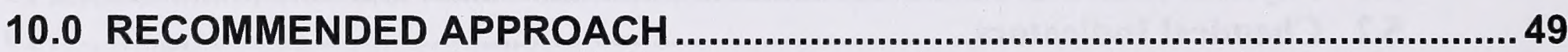

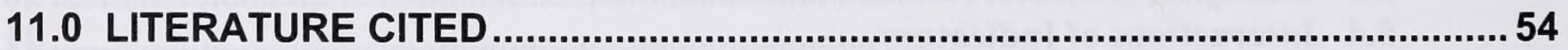




\section{LIST OF TABLES}

Table 1 Summary of GENERAL functions of global wetlands.............................................. 3

Table 2 Prairie and aspen parkland wetland classes and subcategories (from NWWG 1988).. 8

Table 3 Prairie wetland classes: Stewart and Kantrud (1971) …………………................ 9

Table 4 Specific functions and values of wetlands in Alberta; regions are prairie (P), aspen parkland (AP) and boreal dry mixedwood (BDM) .................................................. 12

Table 5 Common biological, chemical and physical indicators of wetland ecosystem health and quality

Table 6 Summary of physical, chemical and biological attributes measured in wetlands in the Prairie region of North America and Canada's (mostly Alberta) Aspen Parkland and Boreal Dry Mixedwood regions, as well as attributes commonly measured in other North American wetland systems.

Table 7 Potential indicators in the primary literature from studies in the Prairie region of North America, the Aspen Parkland region of Alberta and British Columbia, and the Boreal Dry Mixedwood region of Alberta. These indicators were successful in identifying some aspect of wetland "health", i.e. they appeared to respond in a predictable manner to disturbance. 


\section{LIST OF FIGURES}

Figure 1 Boreal dry mixedwood, aspen parkland and prairie regions in the province of Alberta

Figure 2 Framework for choosing potential indicators and combining those indicators into a multimetric index to identify wetland health (adapted from Karr et al. 1986 and US EPA 2002c)

Figure 3 Suite of indicators potentially useful for determining wetland health in Alberta's Prairie, Aspen Parkland and Boreal Dry Mixedwood regions (adapted from Jacques Whitford Inc. 2005) 


\section{LIST OF APPENDICES}

Appendix 1 Matrix of papers of wetland indicators .76

A Review of indicators of wetland health and function in Alberta's prairie, aspen parkland and boreal viii dry mixed wood regions 


\section{ACKNOWLEDGEMENTS}

This project was funded by the Water Research Users Group, Alberta Environment. We thank Anne Marie Anderson, Kim Wescott, Jonathan Thompson, Silvie Forest and Carly Greenway for their advice and help. 


\subsection{INTRODUCTION}

The main objective of this report is to identify potential indicators of wetland health in Alberta, specifically in the prairie, aspen parkland and boreal dry mixedwood ecozones of the province. Potential indicators of wetland health may be physical, chemical or biological in nature. The potential indicators were identified and evaluated for suitability based on scientific studies conducted in wetlands within the Province of Alberta and within other North American wetlands.

This research supports the Government of Alberta's mandate of the Water for Life strategy to invest in knowledge on Healthy Aquatic Ecosystems. Identifying potential indicators will facilitate the development of a framework to monitor and evaluate the health of Alberta's natural, disturbed, and restored wetlands.

This research was conducted using review and synthesis of the primary literature on indicators and ecological characteristics of wetlands in North America. This project therefore does not include identification of potential indicators of health for expansive peatlands in the northern part of the province, nor wetlands in the oil sands region of the province. Rather, emphasis is specifically on identifying potential indicators in the open water and emergent vegetation zones of wetlands in Alberta's prairie, aspen parkland and boreal dry mixedwood regions. These areas were the focus of the study because they represent areas with abundant wetlands as well as the highest amounts of anthropogenic disturbance to wetlands within the province. 


\subsection{GENERAL FUNCTIONS AND VALUES OF FRESHWATER WETLANDS}

\subsection{Wetlands defined}

Wetlands are unique ecosystems that represent a transitional area between terrestrial and aquatic systems where the water table is at or near the land surface. Wetlands therefore are defined as being periodically or continually inundated by water with soils and vegetation characteristic of wet conditions (Tarnocai 1980). For the purposes of this report, wetlands are specifically defined as areas of shallow open water surrounded by a fringe of emergent vegetation and shrubs in either organic or mineral soils. This definition includes riparian wetlands and peatlands (which may or may not have open water), however, these wetland systems will not be included in this report. The focus here is on the open water and the emergent or forested fringe adjacent to the open water zone.

These wetland ecosystems can be highly productive and biologically diverse and thus provide several direct benefits to humans in the forms of products, food, energy, and resources, and indirect benefits from wetland functions such as flood control, nutrient retention and groundwater recharge. Unfortunately, wetlands are also the most threatened ecosystems on earth; over half of global wetlands have already been destroyed (Mitsch and Gosselink 2000).

\subsection{The Canadian Wetland Classification System}

In Canada, wetlands are classified into five classes: bogs, fens, marshes, swamps and shallow open water (National Wetlands Working Group 1997). Bogs and fens are peatlands, defined as having greater than $40 \mathrm{~cm}$ of accumulated, weakly decomposed peat deposits (NWWG 1998). Bogs are ombrotrophic, are often Sphagnum moss dominated, and are nutrientpoor. They are isolated from mineral waters and receive nutrients from precipitation only. Fens are also peat-accumulating, but in addition to precipitation receive nutrients from groundwater and runoff from surrounding areas resulting in a gradient of mineral richness from poor to extremely rich.

Swamps are wetlands characterized by tall trees and/or shrubs and seasonal or persistent standing or slow-moving water. Swamps are generally oxygen and nutrient-rich due to subsurface flow of mineral water and fluctuating water tables. Marshes are periodically inundated wetlands on mineral soil, however in some low boreal areas marshes can also accumulate significant sedimentary peat deposits (Bayley and Mewhort 2004). Marshes are characterized by relatively high oxygen concentrations, $\mathrm{pH}$ and emergent vegetation such as reeds, rushes and sedges. Shallow open water wetlands are small bodies of shallow standing water of less than $2 \mathrm{~m}$ depth in midsummer. Open water wetlands represent a transition between marshes and lakes. They are free of emergent marsh vegetation, but can support submersed aquatic vegetation (SAV). 


\subsection{The US Wetland Classification System}

The Stewart and Kantrud (1971) wetland classification system was developed for the glaciated prairie region of the USA and is applicable for the Canadian prairie regions as the areas share a very similar natural history and present climate. It is structured into a hierarchy of categories with the most general category of 'System', which describes wetlands influenced by similar geological and hydrological factors. Most freshwater wetlands in the United States are classified into the Palustrine System. The Palustrine System consists of non-tidal wetlands that are dominated by trees, shrubs, and/or emergent vegetation or small areas (less than 20 acres) of wetlands lacking vegetation, but with water depth of less than $2 \mathrm{~m}$. This system is further divided by dominant wetland vegetation and substrate composition as well as water regime (surface inundation of water) and water chemistry (pH categories). In the prairie region, Stewart and Kantrud (1971) incorporate the prairie pothole classification, a system divided into Classes I through VII wetlands which will be described later.

\subsection{Global and National Importance of Wetlands}

Estimates of global wetland coverage vary and are often thought to be underestimated; however, the general approximation is that $6 \%$ of the Earth's surface is covered by wetlands (Matthews and Fung 1987, Mitchell and Prepas 1990). Approximately one quarter of global wetlands are located in Canada, and cover approximately $14 \%$ of the national land surface (NWWG 1988).

Wetlands are among the most productive and diverse ecosystems in the world and, despite their small global coverage, they account for $25 \%$ of global productivity. Freshwater wetlands, which cover only $1 \%$ of the Earth's surface, contain $40 \%$ of the world's species (Ducks Unlimited 2004). Wetlands are biogeochemically and biologically active because of their unique permanent or semi-permanent flooded nature and their natural physical, chemical and biological functions, many of which provide great value to humans (Table 1).

\section{Table 1 Summary of GENERAL functions of global wetlands}

\begin{tabular}{|c|c|c|}
\hline & Function & Value \\
\hline Physical & $\begin{array}{l}\text { - Groundwater } \\
\text { recharge/discharge } \\
\text { - Flood water storage } \\
\text { - Erosion control } \\
\text { - Peat accumulation }\end{array}$ & $\begin{array}{l}\text { Water availability/water } \\
\text { storage and flood } \\
\text { attenuation } \\
\text { - Flood moderation; base } \\
\text { flow provider } \\
\text { - } \text { Sediment trapping } \\
\text { - Accumulation of } \\
\text { nutrients (e.g., carbon); } \\
\text { peat extraction for energy } \\
\text { \& horticulture }\end{array}$ \\
\hline
\end{tabular}

A Review of indicators of wetland health and function in Alberta's prairie, aspen parkland and boreal dry mixed wood regions 


\begin{tabular}{l|l|l}
\hline Chemical & $\begin{array}{l}\text { Nutrient/toxicant } \\
\text { removal }\end{array}$ & $\begin{array}{l}\text { Improves water quality } \\
\text { Biological }\end{array}$ \\
\hline $\begin{array}{l}\text { Habitat for wildlife } \\
\text { and waterfowl }\end{array}$ & $\begin{array}{l}\text { Diverse communities; } \\
\text { hunting and fishing; } \\
\text { breeding, nesting and } \\
\text { staging areas for } \\
\text { waterfowl } \\
\text { Basis of the food chain } \\
\text { within and out of } \\
\text { wetlands. Nutrient } \\
\text { removal (uptake), peat } \\
\text { accumulation }\end{array}$ \\
\hline
\end{tabular}

\subsection{Physical Functions of Wetlands}

Wetlands perform a variety of hydrological functions including groundwater recharge and discharge. Wetlands have the capacity to store excess water and maintain high water tables, short- and long-term, thereby preventing flooding downstream and maintaining a hydrophytic habitat. Furthermore, excess water stored in wetlands can be a source for recharge of groundwater in times of limited water availability or drought. Wetlands can store excess surface water during times of abundance, releasing it to downstream streams, rivers and lakes. Wetland emergent vegetation plays an important role in erosion control; emergent plants and their root systems can trap sediments, thus stabilizing shorelines.

Peat accumulation in wetlands such as bogs and fens can be significant and removes carbon from the atmosphere; however, carbon and methane release/sequestering is not uniform for all peatland types and varies temporally and spatially (Moore et al. 1998). There are many uncertainties in current peatland carbon - methane cycles as peat accumulation has not been constant over time. Peatlands, as are many prairie wetlands, emit methane for at least part of the year (Moore et al. 1998). Overall, global carbon/methane budgets of wetlands are not fully understood.

\subsection{Chemical Functions of Wetlands}

Wetlands are effective at retaining and storing nutrients such as nitrogen and phosphorus in both sediments and plant tissues. Physical adaptations of wetland plants allow them to be effective at assimilating excess nutrients and slow water movement allows for nutrients to be adsorbed by sediment (White, et. al. 2000, White and Bayley 2001, Mitsch and Gosselink 2000). Nutrient accumulation in wetlands decreases potential for eutrophication downstream. Further, wetlands can absorb moderate amounts of sewage, pesticides and toxicants, thus aiding in purifying water. Metals such as mercury and lead can also be removed. Biogeochemically, wetlands are very active in nutrient cycling and transformation due to the permanent or semipermanent flooding leading to low redox potentials and an environment that is conducive to element transformations (Schlesinger 1991). 


\subsection{Biological Functions of Wetlands}

Wetlands provide habitat for a diverse variety of plants and animals and provide necessary habitat for one third of the endangered, threatened, or vulnerable wildlife species in Canada (Environment Canada 2004). Wetland plant communities can be extremely productive (Mitsch and Gosselink 2000, Thormann and Bayley 1997) and provide food and habitat for numerous animals. Wetlands are extremely important to waterbirds as sites for nesting, feeding and breeding. Approximately $80 \%$ of all North American waterfowl hatch on prairie pothole wetlands (Environment Canada 2004), although southern boreal and boreal wetlands are increasingly recognized as important for waterbirds. Diverse and thriving wildlife communities in wetlands are also important to the recreational and commercial hunting, fishing and trapping industries. Furthermore, wetlands export dead organic matter, providing the basis of the food chain in downstream waters.

Overall, based on all the physical, chemical and biological functions, wetlands in Canada generate an estimated 5 to 10 billion dollars annually in economic returns through estimated flood and erosion control, water quality improvement and recreational uses (Environment Canada 2004). 


\subsection{CHARACTERISTICS AND FUNCTIONS OF ALBERTA WETLANDS}

For the purposes of this report, only wetlands in the prairie, aspen parkland and boreal transition (dry mixed wood) ecozones of Alberta will be reviewed. These ecozones cover the majority of the southern half of the province (Figure 1), thus the large expansive peatlands and oil sands wetlands (found in northern boreal parts of the province) are not considered here. Focus is on the prairie, aspen and boreal transition ecozones because these are located in areas that are most heavily populated. These wetlands have undergone the most severe amounts of modification and disturbance.

\subsection{The Prairie Region of Alberta}

The prairie region of Alberta covers the majority of the south-eastern portion of the province. The ecozone extends into the prairie pothole region of the United States through parts of Montana, North and South Dakota, Minnesota, and Iowa. The landscape is characterized by numerous small depressional wetlands, i.e. potholes, formed by glacial retreat (Winter 1989). The prairie region is a grassland ecozone, while the prairie pothole region usually includes the aspen parkland ecozone as well. In this report when we refer to the prairie region (or the prairie pothole region) we are reviewing literature from primarily grassland areas.

The prairie region is further characterized by a variable climate, with temperature extremes of $-40^{\circ} \mathrm{C}$ to $+40^{\circ} \mathrm{C}$ (Winter 1989). It is not uncommon for prairie wetlands to freeze solidly in the winter. Prairie climate also exhibits long periods of alternating wet and dry conditions. This wet/dry cycle can occur over 10-20 years (Diaz 1986) and results in dynamic changes in wetland vegetation. During drought periods, prairie wetlands may remain dry for years, exposing large mudflats that allow for the germination of emergent vegetation and high productivity. During wet periods wetlands form shallow ponds and emergent vegetation abundance is reduced in this "lake phase" of the cycle (van der Valk and Davis 1978). In many parts of Alberta these are called "sloughs".

Because of precipitation extremes, prairie wetlands have a complex association with regional groundwater and can serve as groundwater recharge and/or discharge sites, depending on climatic variation and underlying substrate.

\subsubsection{Classes of Wetlands Present - The Canadian Wetland Classification System}

According to the Canadian Wetland Classification System (NWWG 1998), the majority of prairie wetlands in Alberta are marshes and shallow open water wetlands, although some fens are present in the boreal mixed wood ecozone. Alberta prairie marshes are typically dominated by grasses, rushes and sedges. Shallow open water wetlands are often bordered by emergent marsh species such as cattails (Typha latifolia). Seasonal drought can cause water level drawdowns in these ponds, resulting in drying basins that are rapidly colonized by annual plants. Reflooding will again fill the basin, killing colonizing plants and reverting back to a marsh stage with emergent vegetation. Prairie wetlands are dynamic, changing seasonally or annually in water regime, which in turn changes vegetation structure and diversity. 


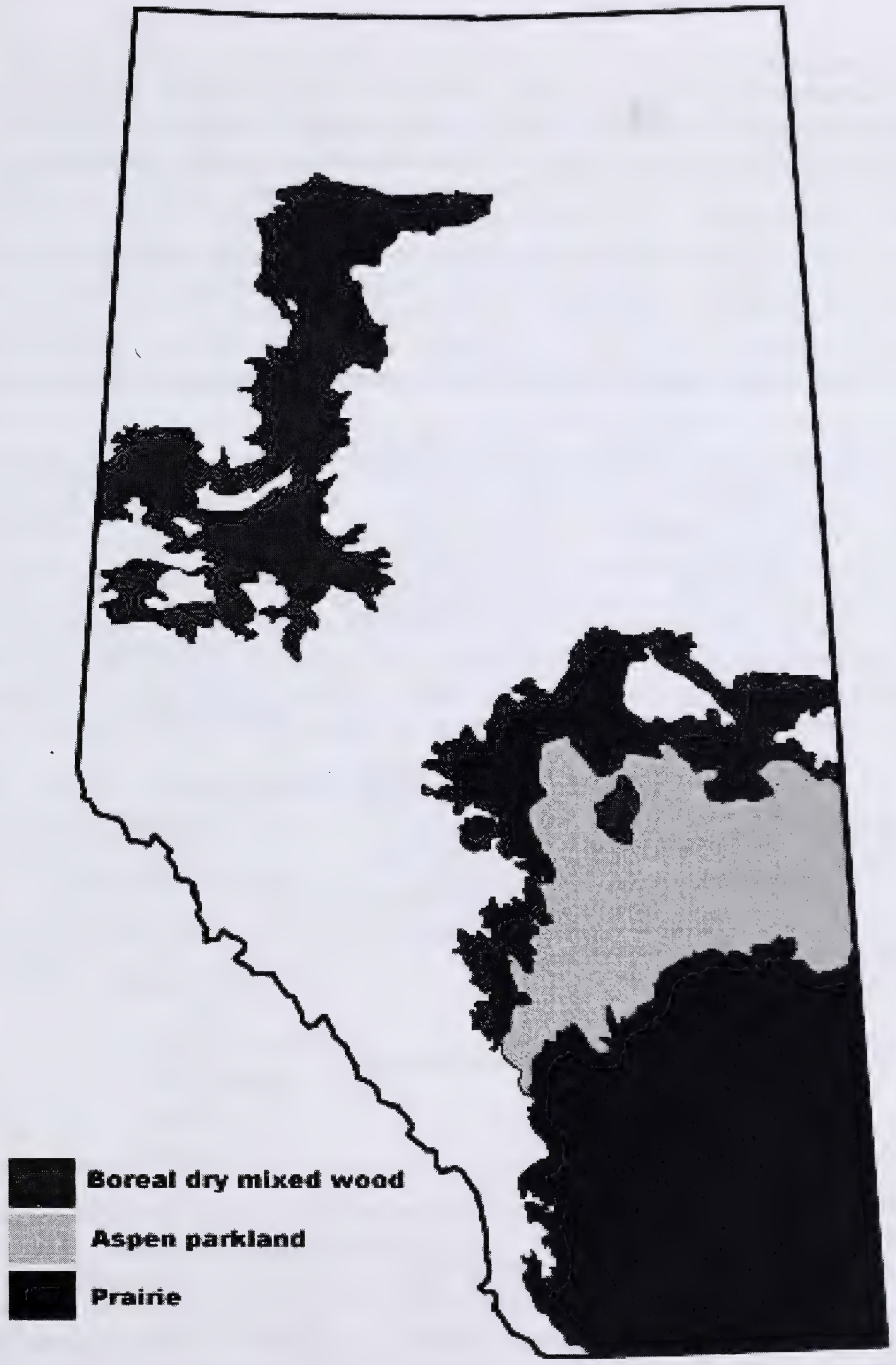

Figure 1 Boreal dry mixedwood, aspen parkland and prairie regions in the province of Alberta

A Review of indicators of wetland health and function in Alberta's prairie, aspen parkland and boreal dry mixed wood regions 
Prairie wetland classes (i.e., marsh, open water and fen) are further divided into forms, subforms, and types (NWWG 1988) (Table 2). Wetland forms are defined by surface morphology, including topography (glacial or water-eroded), mineral deposits, and by hydrologic features such as groundwater linkages. Common marsh wetland forms include glaciated basins and kettles, and water-eroded streams and floodplains. Shallow open water wetlands in the prairies are classified into forms such as channel, delta, kettle, and basin shallow water. Prairie fens form in shallow basins (basin fens) or at groundwater discharge sites (spring fens).

Table 2 Prairie and aspen parkland wetland classes and subcategories (from NWWG 1988)

\begin{tabular}{|c|c|c|c|}
\hline Class & Form & Subform & $\begin{array}{r}\text { Type } \\
\end{array}$ \\
\hline Marsh & $\begin{array}{l}\text { - Delta } \\
\text { - Channel } \\
\text { - Floodplain } \\
\text { - Kettle } \\
\text { - Shore } \\
\text { - Stream } \\
\text { - Basin }\end{array}$ & $\begin{array}{l}\text { - Deep marsh } \\
\text { - Shallow marsh } \\
\text { - Wet meadow }\end{array}$ & $\begin{array}{l}\text { - Low or tall rush } \\
\text { - Mixed grass } \\
\text { - Mixed forb } \\
\text { - No vegetation } \\
\text { - Sedge } \\
\text { - Sedge-grass } \\
\text { - Tall grass } \\
\text { - Tall shrub } \\
\end{array}$ \\
\hline $\begin{array}{c}\text { Shallow } \\
\text { water }\end{array}$ & $\begin{array}{l}\text { - Channel water } \\
\text { - Delta water } \\
\text { - Kettle water } \\
\text { - Oxbow water } \\
\text { - Basin water } \\
\text { - Shore water } \\
\text { - Stream water }\end{array}$ & $\begin{array}{l}\text { - Intermittent } \\
\text { open water } \\
\text { - Intermittent } \\
\text { saline lake } \\
\text { - Permanent open } \\
\text { water }\end{array}$ & $\begin{array}{l}\text { - Floating aquatic } \\
\text { - Submerged aquatic } \\
\text { - No vegetation }\end{array}$ \\
\hline Fen & $\begin{array}{l}\text { - Basin } \\
\text { - Spring }\end{array}$ & - No subforms & $\begin{array}{l}\text { - Low shrub } \\
\text { - Sedge } \\
\text { - Sedge-grass } \\
\text { - Tall grass } \\
\text { - Tall rush } \\
\text { - Tall shrub }\end{array}$ \\
\hline
\end{tabular}

Wetland forms are further divided into wetland subforms. For prairie marshes, these subforms are either shallow or deep-water marshes; shallow marshes are typically at the edges of ponds and go through typical flooded and draw-down stages resulting in semi-permanent flooding. Deep marshes typically remain flooded throughout summer with $10-30 \mathrm{~cm}$ of water (Walker and Coupland 1970). Shallow water wetlands are classified into subforms based on the periodicity of open water, i.e., either intermittent or permanent. Intermittent open water is an area that alternates between open water during wet years and shallow marshes or draw-downs during drier periods i.e., it is a transitional area of open water. Permanent open water wetlands are stable open waters at the deepest part of a basin. 
Wetland subforms are classified into wetland types according to the dominant vegetation in the basin, usually emergent species such as rushes, sedges, grasses or combinations of dominant species. Open water prairie wetlands are defined by aquatic vegetation present, either floating or submerged. Prairie fens are defined by dominant vegetation, primarily shrubs, sedges and grasses.

\subsubsection{Classes of Wetlands Present - Stewart and Kantrud (1971) classification}

In the United States, prairie pothole wetlands are classified into seven classes, each defined by a specific vegetation zone that is present at the centre of the wetland and occupies greater than $5 \%$ of the wetland area, however other wetland vegetation zones may also be present (Table 3).

Prairie wetlands of Alberta are dominated by temporary (Class II), seasonal (Class III) and semi-permanent (Class IV) classes. Stewart and Kantrud's (1971) classification is congruent with the Canadian Wetland Classification System (NWWG 1989) of marshes (shallow and deep) and shallow open water wetlands (both intermittent and permanent). However, Stewart and Kantrud (1971) identified additional classes of permanent (Class V), alkali (Class VI) and fen (Class VII) wetlands that are not as common in the prairie region of Alberta. Due to the dynamic climate in the prairie region, vegetation zones often shift from one type to another during times of drought or excess water, and therefore wetland classes also change. For example, during periods of high precipitation a temporary wetland may shift to a seasonal wetland.

Table 3 Prairie wetland classes: Stewart and Kantrud (1971)

\begin{tabular}{|c|c|c|c|}
\hline Class & Name & $\begin{array}{l}\text { Dominant } \\
\text { Vegetation } \\
\text { Zone } \\
\end{array}$ & Description \\
\hline I & $\begin{array}{c}\text { Ephemeral } \\
\text { ponds }\end{array}$ & Low prairie & $\begin{array}{l}\text { Porous soil and rapid water } \\
\text { seepage after ice melt in } \\
\text { spring } \\
\text { - Emergent vegetation, mostly } \\
\text { grasses, but may be open } \\
\text { water and submersed } \\
\text { vegetation in early spring } \\
\text { when flooded }\end{array}$ \\
\hline II & $\begin{array}{c}\text { Temporary } \\
\text { ponds }\end{array}$ & Wet meadow & $\begin{array}{l}\text { Flooded after spring melt, } \\
\text { heavy rains } \\
\text { Typically emergent } \\
\text { vegetation such as short } \\
\text { grasses, rushes and sedges }\end{array}$ \\
\hline III & $\begin{array}{l}\text { Seasonal ponds } \\
\text { and lakes }\end{array}$ & Shallow marsh & $\begin{array}{l}\text { - Surface water in spring and } \\
\text { summer but may dry in late } \\
\text { summer and fall } \\
\text { - Phases of submersed plants } \\
\text { when open water, emergent }\end{array}$ \\
\hline
\end{tabular}

A Review of indicators of wetland health and function in Alberta's prairie, aspen parkland and boreal 


\begin{tabular}{|c|c|c|c|}
\hline & & & $\begin{array}{l}\text { grasses and annuals with } \\
\text { water draw-downs to bare } \\
\text { soil }\end{array}$ \\
\hline IV & $\begin{array}{c}\text { Semi- } \\
\text { permanent } \\
\text { ponds and lakes }\end{array}$ & Deep marsh & $\begin{array}{l}\text { Surface water throughout } \\
\text { spring and summer and } \\
\text { frequently through fall and } \\
\text { winter } \\
\text { - Normally emergent and } \\
\text { open water submersed or } \\
\text { floating vegetation } \\
\text { - Bare soil (no vegetation) } \\
\text { stage during drought }\end{array}$ \\
\hline $\mathbf{V}$ & $\begin{array}{c}\text { Permanent } \\
\text { ponds and lakes }\end{array}$ & Open water & $\begin{array}{l}\text { - Open water always present } \\
\text { - Submersed vegetation in } \\
\text { shallow water, no vegetation } \\
\text { in deeper water } \\
\text { - May be emergent vegetation } \\
\text { toward shore, but not in the } \\
\text { centre of the open water }\end{array}$ \\
\hline VI & $\begin{array}{l}\text { Alkali ponds } \\
\text { and lakes }\end{array}$ & $\begin{array}{l}\text { Intermittent } \\
\text { alkali }\end{array}$ & $\begin{array}{l}\text { Saline shallow waters and } \\
\text { exposed salt flats during } \\
\text { drought } \\
\text { - Salt-tolerant submersed } \\
\text { plants may be present }\end{array}$ \\
\hline VII & Fen ponds & Fen & $\begin{array}{l}\text { Isolated along peripheries of } \\
\text { ponds, often floating } \\
\text { - May not be surface water } \\
\text { - Willows (Salix spp.), sedges } \\
\text { (Carex spp.) are common }\end{array}$ \\
\hline
\end{tabular}

\subsection{The Aspen Parkland Region of Alberta}

The aspen parkland region of Alberta covers approximately $12 \%$ of the provincial land surface (Strong and Leggat 1981). The aspen parkland region is divided into three subregions: central parkland, Peace River parkland and foothills parkland. The parkland region is a transitional region between dry grasslands and prairie to the south and boreal forest to the north. The region has rolling terrain with abundant lakes, rivers and wetlands created by glacial meltwater. Glacial deposits form moraines and depressions which fill with water to form wetlands.

Climate of the aspen parkland region is wetter than the prairie region to the south, and is marked by cold temperatures, with an average annual temperature of $2{ }^{\circ} \mathrm{C}$ (Environment Canada 2004). The southern parkland region is dominated by grasses with aspen in moist depressions, while the northern, moister part is continuous forest. 
Today, the native aspen parkland is highly fragmented by land use disturbances, especially to support agriculture. It is the most densely populated and most highly disturbed landscape in Alberta.

\subsubsection{Classes of Wetlands Present}

Wetlands present in the aspen parkland are mostly marsh and shallow open water classes, similar to the types of wetlands found in the prairie region of the province (Table 2) (NWWG 1988). Marshes and shallow open water wetlands in the aspen parkland region may be slightly wetter (deeper) and more permanent due to the moister climate.

\subsection{The Boreal Mixedwood Region of Alberta}

The boreal mixedwood region of Alberta is a transitional area between the prairies and parklands to the south and the boreal forest to the north. It is the largest ecozone in the province, covering approximately $43 \%$ of the land surface (Strong and Leggat 1992). The mixedwood region extends across the north-central part of the province. This area is further subdivided into three subregions based on summer precipitation: dry mixedwood, moist mixedwood and wet mixedwood (Strong and Leggat 1992). Topography of the boreal mixedwood region is characterized by rolling terrain, moraines and lacustrine deposits, and a few areas of dunes and sandy outwash material. Jack pine is the dominant tree species in sandy areas and aspen occur in moister areas. Fires frequently burn stands in the mixedwood region maintaining these forest types. Recently, boreal mixedwood forests have been disturbed by forestry and oil and gas activities, resulting in well pads, and road and pipeline networks.

Boreal mixedwood climate is characterized by short, cool summers and long, cold winters. The mean summer temperature is $12^{\circ} \mathrm{C}$ and the mean winter temperature is $-15.5^{\circ} \mathrm{C}$. Most precipitation occurs in the summer with June and July being the wettest months and the winters are relatively dry.

\subsubsection{Classes of Wetlands Present}

Peatlands (bogs and fens) are the dominant wetland class in the boreal mixedwood region of Alberta. Peat consists of partially decomposed vegetative material and accumulates due to decreased decomposition in the cool and anoxic environment (Moore 2002). Bogs are typically dominated by Black Spruce and Sphagnum mosses and fens of the region are dominated by various species, including Sphagnum mosses, trees, birch and willow shrubs, sedges, grasses and brown mosses (Zoltai and Vitt 1995). Marsh wetland types are also found in the boreal mixedwood region, however they are most commonly found at the fringes of open water wetlands and fens. Marshes surrounding depressional ponds in this region have been found to accumulate significant sedimentary peat deposits (Bayley and Mewhort 2004).

\section{Again, this review will consider only the shallow open water wetlands with adjacent peatland vegetation nearby; the expansive vegetated peatlands will not be considered.}




\subsection{Functions and values of Alberta Wetlands}

Natural functions of Alberta's wetlands in all three regions (prairie, aspen parkland and boreal mixedwood) are all similar and have common values to the ecosystems and humans (Table 4).

Table 4 Specific functions and values of wetlands in Alberta; regions are prairie (P), aspen parkland (AP) and boreal dry mixedwood (BDM).

\begin{tabular}{|c|c|c|c|}
\hline \multicolumn{2}{|c|}{ Function } & Value & Region* \\
\hline \multirow{4}{*}{ Biological } & Waterfowl habitat & $\begin{array}{l}\text { - Breeding, feeding and } \\
\text { nesting grounds } \\
\text { - Biodiversity } \\
\text { - Recreational hunting and } \\
\text { viewing }\end{array}$ & $\begin{array}{l}\mathrm{P}, \mathrm{AP} \text { and } \\
\text { BDM; most } \\
\text { prevalent in the } \\
\text { P region of } \\
\text { Alberta }\end{array}$ \\
\hline & Wildlife habitat & $\begin{array}{l}\text { - Feeding, breeding, shelter, } \\
\text { territory } \\
\text { - Biodiversity } \\
\text { - Habitat for endangered } \\
\text { species } \\
\text { - Recreational hunting, } \\
\text { viewing }\end{array}$ & $\mathrm{P}, \mathrm{AP}, \mathrm{BDM}$ \\
\hline & Aquatic habitat & $\begin{array}{l}\text { - Diverse invertebrate and } \\
\text { insect communities } \\
\text { - Food for other wildlife } \\
\text { - Recreational fishing }\end{array}$ & $\mathrm{P}, \mathrm{AP}, \mathrm{BDM}$ \\
\hline & $\begin{array}{l}\text { Wetland plant } \\
\text { community habitat }\end{array}$ & $\begin{array}{l}\text { - Erosion control } \\
\text { - Sediment trapping and } \\
\text { shoreline stabilization } \\
\text { - Production } \\
\text { - N fixation } \\
\text { - Biodiversity }\end{array}$ & $\begin{array}{l}\mathrm{P}, \mathrm{AP}, \mathrm{BDM} ; \\
\text { especially } \\
\text { important in } \mathrm{P} \\
\text { and AP } \\
\text { emergent marsh } \\
\text { vegetation } \\
\text { communities }\end{array}$ \\
\hline
\end{tabular}




\begin{tabular}{|c|c|c|c|}
\hline \multirow{3}{*}{ Chemical } & Biogeochemistry & $\begin{array}{l}\text { - Nutrient cycling } \\
\text { - Element transformations } \\
\text { - N removal via } \\
\text { denitrification } \\
\text { - P removal via organic } \\
\text { matter buildup }\end{array}$ & P, AP, BDM; \\
\hline & Plant communities & $\begin{array}{l}\text { - Removal of } \mathrm{N} \text { and } \mathrm{P} \text { from } \\
\text { water and overland flow } \\
\text { - Removal of pesticides, } \\
\text { toxicants } \\
\text { - Reduction after chemical } \\
\text { and oil spills } \\
\text { - Sediment trapping and } \\
\text { shoreline stabilization }\end{array}$ & $\begin{array}{l}\mathrm{P}, \mathrm{AP}, \mathrm{BDM} ; \\
\text { important in } \mathrm{P} \\
\text { and AP in } \\
\text { urban and } \\
\text { agricultural } \\
\text { areas with } \\
\text { heavy chemical } \\
\text { and pesticide } \\
\text { use }\end{array}$ \\
\hline & Microbial activity & $\begin{array}{l}\text { - Reduction of pathogens in } \\
\text { urban overland and } \\
\text { subsurface flow }\end{array}$ & $\begin{array}{l}\mathrm{P}, \mathrm{AP}, \mathrm{BDM} \\
\text { especially in } \\
\text { urban areas of } \\
\text { the AP }\end{array}$ \\
\hline \multirow[t]{3}{*}{ Physical } & $\begin{array}{l}\text { Groundwater } \\
\text { recharge }\end{array}$ & $\begin{array}{l}\text { Water available for } \\
\text { irrigation in agricultural } \\
\text { areas } \\
\text { - Water available for urban } \\
\text { areas }\end{array}$ & $\begin{array}{l}\mathrm{P}, \mathrm{AP}, \mathrm{BDM} \text {; } \\
\text { important in } \mathrm{P} \\
\text { where there is } \\
\text { extensive } \\
\text { agriculture }\end{array}$ \\
\hline & $\begin{array}{l}\text { Groundwater } \\
\text { discharge }\end{array}$ & $\begin{array}{l}\text { Maintains wet } \\
\text { environments for habitat } \\
\text { and recreation } \\
\text { - Water discharge in drought }\end{array}$ & $\begin{array}{l}\mathrm{P}, \mathrm{AP}, \mathrm{BDM} \text {; } \\
\text { important in } \\
\text { areas } \\
\text { influenced by } \\
\text { drought, } \\
\text { especially } \\
\text { BDM and } \mathrm{P}\end{array}$ \\
\hline & Water storage & $\begin{array}{l}\text { Flood attenuation after } \\
\text { heavy rains and spring melt } \\
\text { - Reduction of soil erosion } \\
\text { and floodwater damage to } \\
\text { urban and agricultural areas }\end{array}$ & $\begin{array}{l}\mathrm{P}, \mathrm{AP}, \mathrm{BDM} ; \\
\text { especially in } \\
\text { disturbed areas }\end{array}$ \\
\hline
\end{tabular}




\begin{tabular}{|l|l|l|l|}
\hline Peat accumulation & $\begin{array}{l}\text { - } \begin{array}{l}\text { Net storage of carbon may } \\
\text { offset climate warming and } \\
\text { greenhouse gases }\end{array} \\
\text { - Storage of N in peat } \\
\text { - Peat extraction for energy } \\
\text { and/or horticultural uses }\end{array}$ & $\begin{array}{l}\text { Prost important } \\
\text { in BDM which } \\
\text { has bogs and } \\
\text { fens; few peat- } \\
\text { based systems } \\
\text { in AP and P } \\
\text { regions }\end{array}$ \\
\hline
\end{tabular}

\subsubsection{Biological Functions}

One of the most important functions of Alberta wetlands is to provide habitat for a variety of organisms, including plant species, waterfowl, fish, insects and other wildlife. The unique habitat of wetlands provides a valuable life support function in the forms of food, shelter and habitat for wet-adapted plant and animal species. It is estimated that in Alberta over 200 species of waterfowl, 16 species of mammals and 11 species of reptiles are directly dependent on wetlands, and countless others are indirectly dependent on wetlands for life support (Alberta Environmental Protection 1999).

Alberta wetlands are especially important to waterfowl as sites for nesting, breeding, and feeding. Northern wetlands in the province, such as those in the boreal mixedwood region, are still important habitats for waterbirds, however they typically support lower densities of birds than wetlands of the prairies and parkland (AEP 1993, Prescott 1995). Boreal wetlands may become a more important site for breeding and nesting of waterfowl during times of drought in the southern part of the province. Further, although boreal bird density in boreal wetlands is less compared to the prairies, the overall number of waterbirds in the boreal forest is just being recognized. Shallow depressional marshes and open water wetlands characteristic of the prairie and aspen parkland regions are especially important to waterfowl species. These shallow, warm water wetlands provide ideal habitat for a variety of invertebrates which are a food source for ducks and other waterbirds (e.g., geese, herons, swans, cranes). Marsh emergent vegetation provides cover and protection for nests and chicks.

Alberta wetlands provide habitat and life support functions for several threatened or endangered bird species in Canada, including the peregrine falcon, piping plover, and whooping crane. These species are listed as endangered by the Committee on the Status of Endangered Wildlife in Canada (COSEWIC) (COSEWIC 2003).

Wetlands in Alberta are also important habitat for unique hydrophytic vegetation. Wetland vegetation, in addition to its biological productivity and diversity, provides several chemical and physical functions that are discussed later. Wetland plant productivity is generally higher in prairie and parkland marshes than in peatlands of the boreal dry mixedwood region of the province (van der Valk and Davis 1978, Thormann and Bayley 1997, Szumigalski and Bayley 1996,). Wetlands in the province are habitat for several rare vascular plant species (Packer and Bradley 1984). Many of these rare plants are identified in the prairie and aspen parkland region. It is likely that Alberta wetlands are important to several other rare or endangered plant species, but extensive research in this field is lacking, especially in boreal areas 
of the province. However, recently Locky et al. (2005) and Locky and Bayley 2006 have shown boreal forested fens to be important habitats for rare plants. Estimates of threatened or rare plants in the province are most likely underestimated. Rare plants documented in wetlands of boreal Alberta are submerged aquatic species found in shallow open water wetlands, but also plants such as slender leaf sundew (Drosera linearis) or northern pitcher plant (Sarracenia pupurea) (e.g., Forest 2001). Rare plants documented in prairie and parkland wetlands of the province are typically grasses, sedges and herbs located mostly at wetland margins and fringes.

Alberta wetlands support other wildlife, including fish and fur and game species. These species are important economically for recreational and commercial hunting, fishing and trapping. In addition, Alberta wetlands provide habitat to several amphibian and reptile species, many of which are threatened or endangered (Alberta Fish and Wildlife 1991).

\subsubsection{Chemical Functions}

The unique wetland environment provides ideal sites for element transformations and nutrient cycling (Schlesinger 1991). Nutrients, such as nitrogen and phosphorus, are transformed by microbes and vegetation. Large quantities of nitrogen are removed by denitrification and storage in peatlands in the boreal dry mixedwood region (Wray 2005, Mewhort 2000). Large quantities of phosphorus are deposited and retained in organic sediments (White et al. 2000), although Ferone and Devito (2004) showed phosphorous releases in northern peatlands.

One of the most important functions of wetlands in Alberta is the ability to reduce or remove chemicals and nutrients from water. A reduction in water velocity through wetlands and large surface water areas promote longer contact time between contaminated water, sediments and plant roots. Adjacent aerobic and anaerobic conditions in the wetland environment promote chemical reactions and transformations. Wetland plants' hydrophytic adaptations enable direct uptake and storage of nutrients such as nitrogen and phosphorus, thus preventing eutrophication downstream (Mitsch and Gosselink 2000). Furthermore, chemicals such as pesticides and other toxicants, including heavy metals, can be removed from water by adsorption to wetland sediments, uptake by wetland vegetation, and breakdown or consumption by wetland microbial or other decomposer communities (Mitsch and Gosselink 2000). Riparian areas adjacent to shallow open water wetlands may be especially useful for water purification. They filter run-off from the surrounding landscape and can aid significantly in reducing nutrient, sediment, or toxicant loads. Wetlands of the prairie and aspen parkland region may be important in water purification of runoff from surrounding agricultural and urban landscape (Euliss et al. 1999). Increased industrial disturbance in the boreal dry mixedwood region is expected to load nutrients into the landscape (Devito et al. 2000) which could enter into regional wetlands for transformation or storage.

\subsubsection{Physical Functions}

Alberta wetlands provide several physical functions including hydrological functions and physical accumulation of organic material (peat). Wetland hydrology maintains wet habitats and functions. Wetlands are an integral part in the local and regional hydrologic cycle and can influence regional evapotranspiration, precipitation, recharge and discharge (Winter 1989). All Alberta wetlands are potentially important areas for water storage, especially following heavy 
rains and spring snow melt. Water stored in wetlands can prevent flooding downstream and can be released slowly during times of drought to replenish creeks and restore soil moisture. Flood attenuation is especially important in prairie and aspen parkland areas of the province where excess water can be detrimental to urban or agricultural areas.

Prairie wetlands receive most water from spring snowmelt (NWWG 1988), whereas more northern wetlands receive most water from summer precipitation. In spring, flooded prairie wetlands can function as a recharge area, replenishing groundwater supplies (Winter 1989). Shallow depression wetlands can dry later in summer and, as a result, the hydraulic gradient can switch and wetlands can become discharge areas, storing water and attenuating floods during summer storms. Although individual water storage capacity of prairie wetlands may be small due to small basin size, the combined total water storage of several wetlands regionally may be very large in areas with numerous wetlands (Winter 1989). Overall, wetlands in the prairie and aspen parkland regions are more likely to be useful for flood attenuation due to their semipermanent nature. Wetlands of the boreal mixedwood region are generally wetter and more permanent with waterlogged soils, but are still subject to drying in certain years. It is difficult to assign general statements about the role of prairie, parkland and boreal mixedwood wetlands as recharge or discharge sites, since this depends on soil permeability, water flow paths and volume, wetland volume, basin size, precipitation, evapotranspiration and other climate factors.

Wetland vegetation physically impedes soil erosion by trapping sediments. Marsh vegetation at the edges of shallow ponds traps sediments and stabilizes the shorelines (Mitsch and Gosselink 2000). Erosion control is especially important in the prairie and aspen parkland regions of the province to prevent the loss of topsoil from agricultural lands.

Bog and fen wetlands in the boreal dry mixedwood store carbon in the form of accumulated peat (partially decomposed organic matter). This carbon sequestration results in the removal of carbon from the atmosphere which possibly offsets emissions of $\mathrm{C}$ to the atmosphere and reduced climate warming (Gorham 1991). 


\subsection{DEFINING INDICATORS OF HEALTHY WETLAND ECOSYSTEMS}

A healthy wetland ecosystem can be defined as a wetland, including all of its biological, chemical and physical parameters and their interactions that are providing ecological and economic functions (Mitsch and Gosselink 2000). A healthy wetland is one that can support biological communities and has similar physical and chemical characteristics to natural habitats within the same region (Mitch and Gosselink 2000). Wetlands are disturbed by a variety of factors that may be measured directly. For example, we can measure the wetland (or often the species) response to a concentration of a toxicant entering a system. Examples are fish mortality resulting from changes in invertebrate and algal communities and productivity. Because of the numerous pathways of wetland disturbance, measuring all potential disturbances in a wetland and the potential responses/loss of functions within the system is not convenient or practical. The challenge lies in finding methods to evaluate wetland health and to determine the extent to which health has been degraded by measuring a few key parameters, or indicators. These then ideally show a cause-and-effect response. Indicators are useful because they provide information on ecosytem health without measuring numerous processes and parameters, and as such provide time and cost-effective evaluations. However, indicators only provide a general picture of wetland health. For more specific information on a particular disturbance or loss of function, more intensive measurements may be needed.

Indicators of wetland health can be divided into three main categories: biological, chemical and physical (Table 5). Problems arise because many of these factors are interrelated and interact with one another. For example, if a wetland is disturbed chemically e.g., by addition of nutrient-rich water, we may see changes in the nutrient status but may also see changes in the biota, e.g. in the algal community and density. Therefore, it is often impractical to focus indicator measurements on one category, but it may be more effective to evaluate several parameters to assess health and quality of a wetland. In addition, given the variability of natural wetlands, more than one indicator is usually required to quantify changes in wetland state or function (US EPA 2002c).

Table 5 Common biological, chemical and physical indicators of wetland ecosystem health and quality

\begin{tabular}{|c|c|c|c|}
\hline & Indicator & Parameters measured & $\begin{array}{c}\text { Possible responses to } \\
\text { disturbance }\end{array}$ \\
\hline Biological & $\begin{array}{l}\text { Birds } \\
\text { Macro-invertebrates } \\
\text { Amphibians } \\
\text { Zooplankton } \\
\text { Algae } \\
\text { Vegetation } \\
\text { Microbes }\end{array}$ & $\begin{array}{l}\text { Community and/or } \\
\text { population structure, } \\
\text { diversity, species } \\
\text { richness, health of } \\
\text { individuals }\end{array}$ & $\begin{array}{l}\text { Shifts in species } \\
\text { composition, } \\
\text { community structure } \\
\text { Disturbance-tolerant } \\
\text { species dominate }\end{array}$ \\
\hline Chemical & $\begin{array}{l}\mathrm{pH} \\
\text { Turbidity } \\
\text { Dissolved Oxygen } \\
\text { Phosphorus and }\end{array}$ & $\begin{array}{l}\text { Acidity, water clarity, } \\
\text { nutrient status of water, } \\
\text { metals, pesticides, } \\
\text { hydrocarbons, salinity, }\end{array}$ & $\begin{array}{l}\text { Changes in water } \mathrm{pH} \text {, } \\
\text { eutrophication and } \\
\text { algal blooms, anoxic } \\
\text { water and/or sediments }\end{array}$ \\
\hline
\end{tabular}

A Review of indicators of wetland health and function in Alberta's prairie, aspen parkland and boreal 


\begin{tabular}{|c|c|c|c|}
\hline & $\begin{array}{l}\text { Nitrogen } \\
\text { concentrations, } \\
\text { Metals } \\
\text { Pesticides } \\
\text { Dissolved Organic C } \\
\text { Major Ions } \\
\text { Cyanotoxins } \\
\end{array}$ & organics & $\begin{array}{l}\text { - Changes to } \\
\text { biogeochemical } \\
\text { cycling } \\
\text { - Toxic responses by } \\
\text { organisms }\end{array}$ \\
\hline Physical & $\begin{array}{l}\text { Water depth } \\
\text { Temperature } \\
\text { Hydrology } \\
\text { Sediment } \\
\text { composition } \\
\text { Decomposition } \\
\text { Structure }\end{array}$ & $\begin{array}{l}\text { Water availability and } \\
\text { permanence, water } \\
\text { recharge and discharge } \\
\text { capabilities, peat } \\
\text { accumulation } \\
\text { Seasonality of changes } \\
\text { in water depth }\end{array}$ & $\begin{array}{l}\text { Changes in water } \\
\text { storage or discharge } \\
\text { - Changes to ground or } \\
\text { surface water } \\
\text { connectivity } \\
\text { - Increased or decreased } \\
\text { decomposition }\end{array}$ \\
\hline
\end{tabular}

Biological indicators are numerous and are probably the most commonly measured parameters for determining overall wetland ecosystem health. Possible biological indicators include microbial assemblages, algae and vegetation, zooplankton, macro-invertebrates, amphibians, fish and bird communities. Microbial assemblages and community compositions are useful measurements because wetland microbes are responsible for transforming and removing nutrients, metals and organic matter within the system (Mickle 1993). Wetland algal communities are useful as indicators because the dominant species often change with disturbance (Robinson et al. 1997). For example, cyanobacteria forms a very dense algal biomass, and typically dominates eutrophic waters (Murkin et al. 1991). Vascular wetland vegetation is often used as an indicator because characteristic responses to disturbance, including biomass and community composition, are changes that are readily measured. Other wetland biological communities such as birds, amphibians, invertebrates and fish may be useful as indicators because they are often especially vulnerable to wetland disturbance. Such changes can be measured in community structure, population density and overall health and productivity of individuals.

Chemical indicators of wetland health include water and soil chemistry parameters such as nutrient concentrations, dissolved oxygen concentrations, $\mathrm{CEC}$ and $\mathrm{pH}$. In addition, direct measurements of certain contaminants or toxicants may be measured. Nutrient concentrations, especially nitrogen and phosphorus, indicate wetland productivity. Other chemical parameters such as dissolved oxygen concentration and $\mathrm{pH}$ can provide insight into wetland conditions and what types of biological communities can thrive.

Physical indicators include measurements of wetland hydrology and seasonality, including water storage and flow, groundwater connectivity, sediment composition, and organic matter accumulation. Organic matter accumulation and decomposition rates may change in response to chemical and/or physical disturbances such as flooding, draining (Bridgham et al. 1991), or adjacent land use 


\subsection{RELATIONSHIPS BETWEEN WETLAND FUNCTIONS AND INDICATORS}

When the chemical, physical and/or biological aspects of wetland ecosystem are disrupted, functions and associated values can be disrupted or lost. To assess disturbance or the overall health and quality, chemical, physical or biological indicators may be used.

Useful indicators are wetland attributes that respond in a predictable manner along a gradient of human disturbances (US EPA 2002c, d). The most common approaches to determining indicators in wetland systems are listed below, based on the US EPA (2002c). Baseline data from reference systems in the region must be collected first. Such reference wetlands should represent a wide range of conditions or gradients from natural, undisturbed wetlands to those heavily impacted by disturbances. Indicators of the wetland being assessed can then be compared to the baseline data to determine the relative health (Figure 2). Ideally, efficient and practical approaches are selected. Because it is impossible and not cost-effective to measure every biological, chemical or physical indicator of a wetland's quality, we want to measure only those attributes that will accurately reflect the health of the system as a whole. Use of indicators can be problematic however because natural wetland conditions vary so widely and it can be difficult to differentiate between a man-made disturbance and natural variation.

\subsection{Physical Indicators}

Physical indicators can include both structural and process-based measurements. Structural changes can be easier to measure and link to physical processes. Measuring physical processes to indicate wetland health can be difficult and time and cost-consuming. For example, measurement of groundwater connectivity and recharge or discharge sites is expensive, difficult and labour and time intensive. Wetland systems may switch from recharge to discharge systems seasonally or vary within the same wetland at the same time (e.g., one end of a wetland may be a recharge zone and the other end may be a discharge zone) (Ferone and Devito 2004). Physical changes to a wetland's hydrology may occur slowly over time and it can be difficult to monitor those changes. Other physical changes are obvious. Examples are ditching or draining and physical measurements of water levels and/or areas disrupted can be used as indicators. Functions such as water storage, flood control, and peat accumulation may be disrupted by physical disturbances. However disturbances like these may be difficult to actually quantify, especially when the natural physical conditions and hydrology are variable. Instead, reflections or impacts of physical disturbances may be more easily quantified in chemical or biological parameters of the system. For example, changes in water table are often expressed in changes in plant species assemblages.

\subsection{Chemical Indicators}

Water chemistry parameters may be useful for indicating overall wetland health and are typically the first parameters investigated to assess water quality. For example, total phosphorus is strongly correlated to trophic status of wetlands (Bayley and Prather 2003) which is also related to the plant and invertebrate communities present. However, there are numerous chemical parameters to consider and it would be impossible to measure them all. Chemical indicators, 
especially water chemistry parameters, can be problematic because of cost and time requirements. Further, chemical interactions are complex and may be difficult to measure. For example, a particular chemical may degrade or transform quickly and detection may not be possible. Furthermore, it is not cost effective to measure chemical parameters frequently or over a long period of time. Unless there is concern about a specific chemical or contaminant, direct measurements may not provide a general picture of wetland health. Sediment chemistry may provide a better and more long-term picture because chemicals can persist in sediment.

\subsection{Biological Indicators}

Biological indicators are often considered to be the most useful indicators (US EPA 2002d) because it is generally assumed that the plant and animal communities of wetlands most accurately reflect wetland health. Biological indicators considered most useful in assessing wetland health include microbes, vascular and non-vascular plants, invertebrates and birds. Other indicators, such as amphibians, fish and reptiles, are used in selected wetlands but are not reliably found in shallow isolated wetlands.

Measuring microbial assemblages in a wetland can provide information on removal of nutrients and metals from wetlands (Mickle 1993) because certain types of microbes are responsible for each of these functions (Tate 1995). Measurement of microbial community structure can be difficult and total microbial biomass or decomposition rates may be a more useful indicator of microbial activity (Horwath and Paul 1994 and Thormann et al. 1999).

Algal and vascular plant communities are very important in wetland ecosystems because they function as an energy source-for higher organisms. Algal community structure can indicate trophic status of a wetland and therefore nutrient loading. Vascular plant communities, including shrubs, emergent macrophytes, and floating or submersed aquatic vegetation, are sensitive to changes in water and nutrient availability (Keddy 2000) and distinct wetland vegetation communities or zones are often delineated by water level. Many wetland macrophytes are noted for their ability to assimilate pollutants and many of these plants are tolerant to contamination. Changes in community composition, increases in biomass, and changes to plant health are useful indicators. Nutrient loading in wetlands may result in increased plant productivity, increased biomass, and monocultures of nutrient-tolerant species such as cattails. Diversity of plant communities can increase or decrease in response to disturbances (Englund 1991), and therefore measuring plant biomass and dominant species present may be indicative of wetland health. Many shallow lakes are considered healthy if they contain submersed aquatic vegetation (SAV) rather than pelagic algae (Chow-Fraser 1999). Overabundant growth of native species of SAV may not be considered desirable by people, although it can be healthy in an ecosystem context. Wetland trophic status (dominance of submersed aquatic vegetation communities and/or algal communities) is widely used to evaluate wetland health. Marshes and shallow open water wetlands in Alberta, just as lakes, can range from oligotrophic to hypertrophic and measurements of algal or vegetation communities are relative rather than absolute (Bayley and Prather 2003).

Invertebrate communities in wetlands are good indicators of wetland trophic status (growth of SAV and/or algae). Some invertebrate species are specialized for feeding on certain types of aquatic plants (Murkin et al. 1991) and as aquatic plant biomass increases (e.g., with 
increasing nutrient concentrations), so do invertebrates. Invertebrate community structure is also sensitive to changes in disturbance to the landscape surrounding wetlands, including agricultural and urban expansion (Anderson and Vondracek 1999).

Several studies have used bird community composition on wetlands to indicate land use and disturbance of the region surrounding the wetland (Adamus et al. 2001). Chemical contamination to wetlands can affect birds, most likely by altering the vegetation and invertebrates that are consumed by the birds therefore chemical disturbances may be difficult to quantify using birds as indicators.

The following should be considered when using fish, amphibians and reptiles as indicators. The water columns of many shallow wetlands in temperate and boreal regions freeze completely during winter killing the fish and/or other organisms. Further, many of these wetlands have never been colonized by fish. Amphibians are extremely sensitive to a variety of disturbances and hence would make excellent indicators. However they are in decline (Wake 1991) in many areas of Alberta for a variety of reasons and are often not present in otherwise healthy wetlands. Thus, the presence of various amphibians indicates that the wetland is healthy, however the absence of amphibians does not indicate that the wetland is unhealthy. Amphibians may be used as a component in an index of biological integrity but are not likely to be as useful initially in the development of indices for Alberta wetlands.

\subsection{Interactions of Indicators}

Several indicators within a wetland system can be combined to form a multimetric index of the overall health or condition of a wetland site (Figure 2). These metrics may be expressed as a number which is a rating that indicates the amount of deviation of the system from the same values measured in undisturbed systems (Karr and Chu 1999). Combining multiple indicators is useful because it encompasses sensitivity of the system to a wider range of disturbances. Currently this method is being employed in the United States (US EPA 2002c, Rader et al. 2001). 


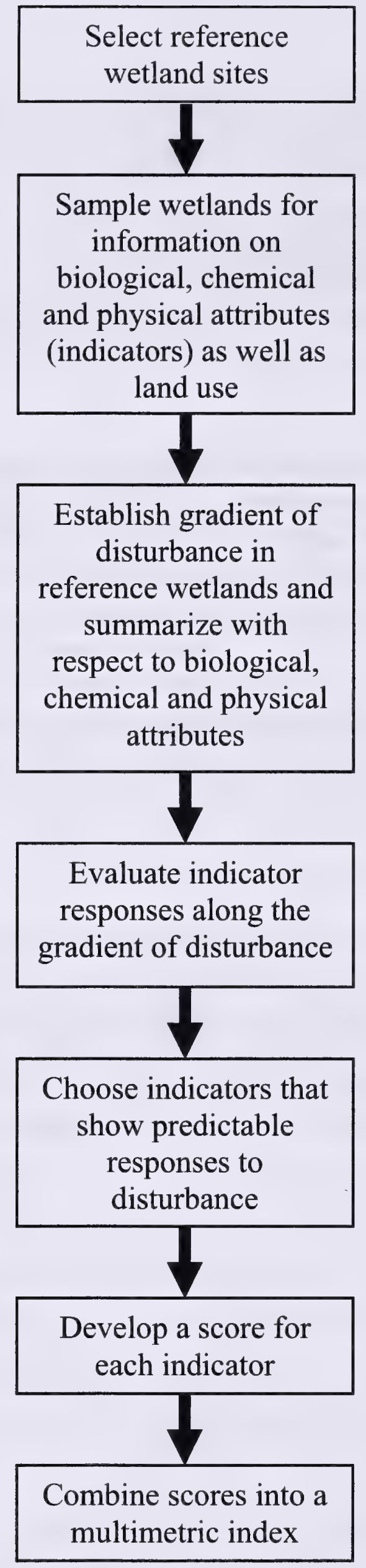

Figure 2 Framework for choosing potential indicators and combining those indicators into a multimetric index to identify wetland health (adapted from Karr et al. 1986 and US EPA 2002c)

A Review of indicators of wetland health and function in Alberta's prairie, aspen parkland and boreal 22 dry mixed wood regions 


\subsection{DISTURBANCES AFFECTING WETLANDS IN ALBERTA'S PRAIRIE, ASPEN PARKLAND AND BOREAL DRY MIXEDWOOD REGIONS}

Many wetlands are in topographically low landscape positions, which make them vulnerable to impacts from disturbances in surrounding landscapes, especially if surface-water and/or run-off fed (Adamus 1992, Denny 1994). Disturbance is defined as events that cause the functions or values of a wetland or a system of wetlands to vary outside of a normal, natural range (Detenbeck et al. 1999). This includes changes to the ecosystem, community or population structure, and/or changes to the physical or chemical environment (Pickett and White 1985). Disturbances with the greatest impacts to wetland functions and values include sedimentation, changes to hydrology, water retention time, biomass removal and nutrient enrichment (Detenbeck et al. 1999). Furthermore, disturbed wetlands are often susceptible to invasions by non-native species (Galatowitsch et al. 2000), a problem which is becoming wide-spread (Vitousek et al. 1996). Further, disturbed wetlands may be quickly colonized by native but aggressive species such as cattails (Typha latifolia). Responses of wetland systems to disturbances generally include shifts in biotic community compositions and/or productivity, decreased diversity or abundance of biota, and decreased water quality (Detenbeck et al. 1999).

In very general terms, healthy wetlands have abundant aquatic vegetation (both emergent and submersed) which reduces turbidity, and sequesters nutrients, whereas systems impacted by disturbance generally have little aquatic vegetation and are turbid and nutrient rich (Chow-Fraser 1999). But note, some wetland types, especially oligotrophic types and/or wetlands on calcium carbonate (e.g. in the foothills) can have clear water but a very sparse plant community (species and mass). Healthy wetlands are generally those that remain close to a pristine, natural state and are not impacted by anthropogenic disturbances. Natural variation is quite common among and within wetland systems (Rose and Crumpton 1996) and should be considered in health assessment. For example, prairie wetlands experience natural, yet dramatic wet/dry fluctuations (van der Valk and Davis 1978), which often have dramatic effects on the vegetation communities (Kantrud et al. 1989). It may be especially difficult to distinguish between natural and anthropogenic disturbance to wetlands in Alberta as natural conditions range so widely.

Disturbances to wetland systems may be natural (water level fluctuations, soil deposition, fires) or anthropogenic (landscape changes, drainage, fragmentation, nutrient input, chemical input) or a combination of natural and anthropogenic influences (climate change) (Niemi et al. 2004). The challenge lies in distinguishing between natural and anthropogenic disturbances and variation in wetland ecosystems (Niemi et al. 2004).

In general, disturbance to wetland systems can be grouped into three categories: 1 . complete loss or destruction of wetlands (resulting in complete loss of wetland functions), 2. direct disturbance, or 3. indirect disturbance to wetlands (resulting in impairment of wetland functions). 


\subsection{Loss and Destruction of Wetlands}

The greatest and most harmful disturbance to global wetlands is the complete loss of wetlands through drainage or filling (Mitsch and Gosselink 2000). In central and southern Alberta, the greatest loss of wetlands occurs as a result of agricultural and urban expansion. Destruction of wetlands for agriculture is especially prevalent in the prairie region of the province (Podruzny et al. 2002, Miller and Duncan 1999, Budelsky and Galatowitsch 2004) which has been used for agriculture for over a century (Kantrud and Newton 1996). In the prairie region, wetlands historically covered $20-60 \%$ of the landscape area, however today the majority of these have been drained to form croplands (Turner et al. 1987). Estimates of wetland loss in the prairie region are approximately $40 \%$ with over $90 \%$ of remaining wetlands adversely affected by agricultural and urban expansion (Turner et al. 1987). The entire prairie pothole region of North America has been transformed from a landscape of grasslands embedded with numerous wetlands to a fragmented agricultural landscape (Naugle et al. 2001, Kantrud 1986) of predominantly cereal and canola crops (Anderson et al. 2002). Currently, approximately $21 \%$ of Alberta's land area is covered with wetlands, most of which are peatlands in the northern part of the province (NWWG 1988). In the parkland region of Alberta, an estimated $60 \%$ of wetlands have been lost in the last century. This number jumps to $75 \%$ in the regions surrounding major cities such as Edmonton, where wetlands have been drained or destroyed by building roads nearby

Temporary or seasonal wetlands are abundant in the prairie pothole region of North America, however they represent the lowest proportion of protected wetlands in the area (Naugle et al. 2001). Because of their extremely dynamic nature, temporary and seasonal wetlands are at greatest risk for loss to agricultural or urban expansion (Zimmer et al. 2001).

Urban expansion is more prevalent in the aspen parkland region of the province, although agricultural expansion is occurring as well (Bjorge 1999), resulting in wetland loss. In the boreal dry mixedwood region of Alberta, agriculture continues to expand into undisturbed lands resulting in the drainage of wetlands. In addition, wetland loss is attributed to exploration and extraction for oil and gas. The boreal forest of Canada comprises $25 \%$ of the world's forests and over $30 \%$ of Canada's boreal landscape is covered with wetlands (World Resources Institute 2000). The southern edge of the boreal forest in western Canada is being rapidly developed and modified for forestry, mining, oil and gas extraction/exploration and recreation (AEP 1999, DUC 2004, Hobson et al. 2002, Westbrook and Devito 2004) and, as a result, less than $17 \%$ of the boreal plain ecozone, including its numerous wetlands, remains as intact, continuous landscape (Lee et al. 2003).

When wetlands are lost or destroyed their associated biological and economic functions are also destroyed completely. This is unfortunate, as natural functions of wetlands may be most beneficial in areas impacted by agriculture and urban expansion due to the natural water purifying characteristics of wetlands (Mitsch and Gosselink 2000). The only chance for regaining the functions and values of 'lost' wetlands is to restore the wetlands that have been destroyed. In the US, widespread restoration of wetlands, especially prairie wetlands, is underway (Gleason et al. 2004). 


\subsection{Direct Disturbances to Wetlands in Alberta}

Direct disturbances (defined as disturbances that occur within an actual wetland complex) to wetlands in Alberta are often related to the same disturbances that destroy wetlands i.e., agricultural expansion, urbanization and resource exploration and extraction. However, there are also natural processes which can disturb wetlands such as beaver (Hood 2007). Many North American freshwater wetlands are closely surrounded by agriculture (McDougal et al. 1997). In Alberta, uplands surrounding wetlands are frequently impacted by cultivation. Bjorge (1999) showed that only $55 \%$ of pond margins and $51 \%$ of uplands in the aspen parkland of Alberta were free from cultivation. In prairie wetlands, cultivation right up to the edge of ponds and marshes encourages encroachment of woody plants such as Salix species into herbaceous wetland vegetation (Kantrud 1986) and invasion of noxious or cropland weeds (Higgins and Barker 1982). Further, expansion of agricultural lands in Canada's prairie regions results in the conversion of native grasslands to croplands (Podruzny et al. 2002, Miller and Duncan 1999) that has been implicated in the decline of waterfowl populations (Podruzny et al. 2002, Bethke and Nudds 1995).

In agricultural areas, wetlands are impacted directly by grazing from cattle and other animals, water extraction for irrigation, direct application of pesticides and other chemicals from spray drift. In regions where agriculture is prevalent, especially in the prairie and aspen parkland regions, irrigation practices may utilize water directly from nearby wetlands and shallow waters, which alters hydrology and, in turn, the vegetation of the wetland systems (Kantrud 1986).

Cattle grazing is becoming an increasing problem for prairie and parkland wetlands in Alberta (Casey et al. 1999) resulting in wetland vegetation loss through herbivory, trampling, and nutrient inputs through cattle waste (Collins et al. 1998, Archer and Smeins 1991). Removal of wetland vegetation by grazing and other herbivory opens the canopy and often results in plant invasions (Galatowitsch et al. 2000). Fire can similarly impact wetland vegetation by reducing height and density of tall emergent vegetation (Kantrud 1986), releasing nutrients, opening the canopy and allowing more light penetration and may enhance biological productivity (Wright and Bailey 1982).

In Alberta, especially in the prairie region, it is suggested that agriculture significantly contributes to degradation of surface and ground water (Miller et al. 1992, Greenlee et al. 2000, Anderson et al. 2002). In the USA, agriculture is the single largest contributor of pollution to surface and groundwater systems (Geleta et al. 1994).

In urban areas, such as the parkland surrounding Edmonton and prairie regions surrounding Calgary, wetlands and wetland health are poorly documented. Crosbie and ChowFraser (1999) found poor documentation of urban wetland loss in other areas of Canada as well. Direct disturbances to existing wetlands include filling of the wetland, building roads through them, changing the hydrologic flow paths (routing urban runoff into wetlands), and conversion of wetlands to stormwater runoff ponds. Edmonton and Calgary have a long history of in-filling and more recently of using their wetlands for stormwater management. However, in 2004 the city of Calgary approved a wetland conservation plan that addresses these issues (City of Calgary 2004). 


\subsection{Indirect Disturbances to Wetlands in Alberta}

Indirect disturbances to wetlands involve disturbances to the surrounding landscape (uplands) and to the riparian areas adjacent to wetlands. Indirect disturbances include upland deforestation, urbanization, infrastructure development (e.g. roads, pipelines, seismic lines) and pollutant runoff (nutrients, sediment, and pesticides). Natural disturbances include fire, flooding and drought that can affect land surrounding wetlands and thus indirectly wetlands. Land use changes can have indirect, but still significant impacts on freshwaters (Soranno et al. 1996), resulting in the loss of wetland functions and values (Walters and Shrubsole 2003). Large-scale human modifications to landscapes have generally negative effects on the health of aquatic ecosystems downstream or nearby (Naiman et al. 1995). Nutrient loading to uplands can impact water systems downstream, including wetlands. Draining, ditching and deforestation in the surrounding uplands and riparian areas can affect wetland biotic communities (Naugle et al. 1999) through changes to wetland water levels (Euliss and Mushet 1996).

Wetland disturbances are prevalent in agricultural landscapes (Euliss and Mushet 1996) especially in the prairie pothole region of North America (Euliss et al. 1999). Indirect impacts of agricultural activity on wetlands include increased sedimentation (Kantrud 1986, Gleason and Euliss 1998, Gleason et al. 2003), nutrient enrichment from agricultural runoff (Koch and Reddy 1992, Neely and Baker 1989, Hann and Goldsborough 1997, Sandilands et al. 2000), drift and runoff of pesticides and other chemicals (Goldsborough ad Crumpton 1998), and the associated alteration of wetland functions and values. In general, prairie wildlife habitat, both wetland and upland, is declining (Dechka et al. 2002) because of these land use changes. In the prairie and parkland regions, these upland activities indirectly affect duck populations (Bethke and Nudds 1995 ) at local and landscape scales. Since availability of suitable habitat determines success of nesting (Johnson et al. 1987), these activities are cause for concern.

Urbanization of uplands surrounding wetlands can have similar indirect impacts, including contamination of waters by septic waste, road salt waste and runoff of these and other chemicals in stormwater that often flows into wetlands (Panno et al. 1999). Construction of roads in urban areas like the aspen parkland, as well as roads and seismic cutlines for resource exploration in the boreal dry mixedwood, fragment the landscape resulting in disturbances to wetlands in the area. Human activities such as these often load nitrogen (and phosphorus) into aquatic systems (Vitousek 1994). Furthermore, fragmented landscapes tend to support fewer species of waterfowl than wetlands in unfragmented landscapes (Naugle et al. 2001).

Agricultural pesticides are a threat to the ecological health of wetlands in the northern prairies and parkland regions of Alberta (Donald et al. 1999). In the Aspen parkland, glyphosate is the most commonly used herbicide and can negatively affect wetland vegetation (Byrtus 2000). Further, wetlands are subject to input of agricultural fertilizers (Crumpton and Goldsborough 1998) and land application of manure which results in nutrient loading (Carpenter et al. 1998) which can result in increased algal productivity and algal blooms (Kim 2003).

Pesticides and fertilizers are indirectly delivered into wetlands by runoff, spray drift, leaching to groundwater and spills (Goldsborough and Crumpton 1998). Agriculture is a major 
source of pollution, but urban land use can also have strong localized effects on water quality and aquatic biota (Paul and Meyer 2001).

Urban expansion in wetland catchments can result in increased stormwater flows which can contain contaminants (Pettigrove and Hoffman 2005). For example, paved road density within wetland vicinity in southern Ontario was related to decreased biotic species richness (Findlay and Houlahan 1997), possibly caused by waters highly enriched with a wide range of contaminants (Birch et al. 2004), many of which are generally persistent in aquatic environments (Winter 1988).

Destruction of natural riparian buffer zones, whether by grazing, burning or tillage, can result in decreased integrity of aquatic systems (Booth and Jackson 1997), including increased soil erosion, sedimentation, eutrophication (Freeman and Schorr 2004), and decreased habitat (Kalff 2002).

\subsection{Climate Change}

Climatic conditions ultimately determine the frequency and position of wetlands in the landscape (Winter 1988) as well as the feasibility of land-use such as agricultural activity (Detenbeck et al.1999). As a result, current and future climate change could have a significant impact on wetlands in the province of Alberta. This may be especially important in the boreal dry mixedwood region of the province where the most southern peatlands in Alberta are found. Peatlands at the southern part of the boreal plain in western Canada are likely to be highly sensitive to climate change disturbances (Kettles and Tarnocai 1999).

In the prairie and parkland regions of the province, global climate change is expected to cause changes in the wet-dry cycles of wetlands (Poiani and Johnson 2003). Semi-permanent wetlands could become seasonal during dry periods and seasonal wetlands could become semipermanent in wet periods (van der Valk 1995). Furthermore, seasonal wetlands, such as those common in southern Alberta, are more vulnerable to climate change than larger, more permanently flooded wetlands (Detenbeck et al. 2003).

In general, disturbances to wetlands either directly or indirectly, are prevalent in Alberta's prairie, aspen parkland and boreal dry mixedwood regions. The challenge lies in finding suitable methods for measuring the impacts of these disturbances on associated functions and values of these wetlands. This is difficult, because studies on Alberta wetlands are rare, especially in the Aspen Parkland (Savard et al. 1994) and boreal dry mixed wood regions. In fact, temperate wetlands in all of North America are not adequately studied or classified (Amon et al. 2002), further inhibiting our abilities to identify good indicators of wetland disturbance. In general, wetland mapping in Alberta has just recently begun at a scale suitable for management and wetland losses have not been adequately quantified in the prairie, parkland or the dry boreal mixedwood regions. 


\subsection{PHYSICAL AND CHEMICAL PARAMETERS AND INDICATORS IN WETLANDS OF ALBERTA'S PRAIRIE, ASPEN PARKLAND AND BOREAL DRY MIXEDWOOD ECOZONES}

Physical and chemical characteristics of wetlands, watersheds and landscapes surrounding wetlands vary naturally and with anthropogenic disturbances. Characteristics include watershed and wetland area, extent of upland disturbance, land-use, extent of riparian zone, water depth, retention time, and nutrient and water quality status.

Water quality parameters commonly measured in wetland studies include nutrient concentrations, $\mathrm{pH}$, conductivity, turbidity and dissolved oxygen. Together, these parameters provide an overall picture of the chemical conditions of the wetland surface water.

Measurements of nutrient concentrations, specifically nitrogen and phosphorus ( $\mathrm{N}$ and $\mathrm{P}$ ) have long been used as an indicator of aquatic ecosystem trophic state, where those waters with high levels of $\mathrm{N}$ and $\mathrm{P}$ are considered eutrophic or hypereutrophic and those with lower concentrations of these nutrients considered mesotrophic or oligotrophic (Mitsch and Gosselink 2000).

Physical characteristics of wetlands and shallow open waters such as surface water depth and retention time generally vary with the class of wetland e.g., fen, marsh, seasonal or semipermanent wetland types (NWWG 1998). When natural flow, retention or depth of water (both ground and surface) are impeded or altered by anthropogenic activities, functions and values of wetlands can change (Swanson et al. 1988). Functions and values of wetlands may be impaired by physical disturbances to landscapes surrounding wetlands or within the wetlands themselves. Disturbances include fragmentation (Kantrud 1986), changes to hydrology, including large fluctuations in water levels (Euliss and Mushet 1996), and destruction or alteration of riparian buffer strips (Crosbie and Chow-Fraser 1999).

The nature and extent of these physical or chemical parameters may be useful as indicators of wetland health in Alberta's prairie, parkland and boreal mixedwood ecozones.

\subsection{Prairie}

Chemical characteristics of wetlands in the prairie region of Alberta and the United States are better-documented than the chemistry of wetlands in other regions of the province. In general, chemical characteristics of prairie wetlands vary widely with disturbance (type and severity) and natural influences (hydrogeochemical influences) (Swanson et al. 1988). Many wetlands in the prairie region of Alberta are rich in phosphorus and can be classified from eutrophic to hypereutrophic (Casey et al. 1999, White and Bayley 2001, Prepas et al. 2001). Factors contributing to nutrient and chemical characteristics of prairie wetlands include soils, vegetation, groundwater flow, land-use and basin characteristics (Shay et al. 1999).

In Alberta, concentrations of total phosphorus (TP) and total nitrogen (TN) in wetlands peaks during spring. In agricultural watersheds in western Canada, this coincides with the majority of runoff from surrounding landscapes (Ontkean et al. 2003). This suggests that nutrient concentrations in surface waters may give an indication of agricultural disturbance. 
However, many prairie wetlands in Alberta, including marshes, may be efficient at removing nutrients from inflowing water (White et al. 2000, White and Bayley 2001, Foote and RiceHornung 2005) and therefore landscape disturbances that contribute nutrients may not necessarily be reflected in $\mathrm{N}$ and P measurements. Detenbeck et al. (2003) found that increased nutrient loading from the surrounding watershed in prairie wetlands resulted in changes to nutrient concentrations in surface waters. However these concentrations changed more dramatically in response to disturbances to water level and vegetation. Furthermore, nutrient retention, and therefore nutrient concentrations, may vary seasonally within wetlands (White and Bayley 2001).

Cattle grazing and increased nutrient input did not show identical results in all wetlands or types of wetlands. Foote and Rice-Hornung (2005) found that nutrient concentrations ( $\mathrm{N}$ and P) did not significantly change with increasing cattle grazing pressure, while Casey et al. (1999) showed that total $\mathrm{P}$, total dissolved $\mathrm{N}$, and inorganic $\mathrm{N}$ (ammonium and nitrate) concentrations in the water column were elevated in ponds with mid- to heavy grazing.

Other water chemistry parameters such as turbidity, dissolved oxygen concentration and temperature did not vary with nutrient addition in Manitoba prairie marshes (Hann and Goldsborough 1997). However, in prairie pothole wetlands in the USA, turbidity was elevated in wetlands with agricultural basins compared to those with partially tilled or untilled basins (Dieter 1991). In a study of shallow ponds in prairie Alberta, Jackson (2003) measured significantly higher concentrations of chlorophyll in turbid compared to clear lakes.

Physical changes to wetland water regimes may be measured in wetlands, including surface area, water depth, and water levels. All of these factors may be affected by disturbances to wetlands or their surrounding areas. Water manipulations can alter salinity, nesting cover and invertebrate food sources utilized by waterfowl (Swanson et al. 1988). Shallow water ecosystems respond in complicated ways to nutrient additions (Moss et al. 1996), possibly due to a diverse community of primary producers such as algae and aquatic macrophytes competing for the same nutrients (Goldsborough and Robinson 1996). Prairie wetlands impacted by agriculture experience greater water level fluctuations compared to wetlands adjacent to native grasslands in the same area (Euliss and Mushet 1996). Such disturbance differences may be difficult to document since natural cyclic water level fluctuations are dramatic in the prairie pothole region (van der Valk 2005, McGowan et al. 2005).

Measuring attributes of riparian buffer zones surrounding wetlands may be useful in assessing health of wetlands in prairie regions. Maintenance of riparian buffer strips alleviates sedimentation from surrounding landscape, including agricultural erosion (Detenbeck et al. 2003). Riparian buffers, when broad and extending into the surrounding agricultural landscape, provide nitrogen retention capacities (Jacks and Norrstrom 2004, Klapproth 2000, Mitsch and Gosselink 2000). Furthermore, bird density is positively related to the amount of riparian buffer area surrounding wetlands as the birds depend on this area for nesting sites and food (Fairbairn and Dinsmore 2001). When wetland perimeters are $<25 \%$ surrounded by woody vegetation, there is a decline in waterfowl species richness due to habitat and nesting cover losses (Naugle et al. 1999). 
Measurement of concentrations of chemicals within wetlands would also give an indication of disturbance or contamination. Insecticide additions into prairie wetlands often result in mortality of macroinvertebrates (Zrum et al. 2000). However, it may be easier to measure concentrations of insecticides in the water rather than consequences to the biotic communities. Unfortunately, pesticides react in various ways in the water column, and while concentrations are generally elevated initially following application, levels generally decrease after a few days (Zrum et al. 2000). In sediments, concentrations of pesticides and other contaminants such as metals are generally more persistent (Helawell 1986, White 1988).

In general, it is difficult to pinpoint single good indicators of prairie wetland health since there is so much natural variation in hydrology and nutrient status among wetlands. Developing indices is especially difficult because there are limited numbers of comparable sites and a lack of minimally disturbed sites that can be used as references (Wilcox et al. 2002). That said, hydrologic or nutrient indicators in conjunction with other biotic indicators may be useful. There are very few studies that document the normal range of variation in water quality in seasonal wetlands or even semi-permanent prairie wetlands (Kantrud et al. 1989) and these wetlands are abundant in the prairie pothole region and are generally more susceptible to disturbances (Detenbeck et al. 2003).

\subsection{Aspen Parkland}

Wetlands in the aspen parkland region of Alberta, like those in the prairie region, are variable in physical and chemical characteristics. This variation may be natural or may be in response to disturbances, it is difficult to distinguish between the two. In general, ponds studied in the aspen parkland are found to be eutrophic to hypereutrophic, based on phosphorus concentrations in the water (Casey et al. 1999, Anderson et al. 2002).

Water chemistry parameters did not change significantly in response to cattle grazing, although TP, ammonium and nitrate concentrations were elevated in ponds with increased grazing (Casey et al. 1999). Furthermore, it appears that chemical changes to wetlands in the parkland region caused by grazing pressure did not affect avian assemblages, which are diverse in most ponds (Casey et al. 1999). In addition, increasing phosphorus concentrations were not correlated with chlorophyll concentrations in the same ponds (Anderson et al. 2002). In wetlands of the aspen parkland of British Columbia, total dissolved nitrogen and calcium in surface water were good indicators of wetland health. Wetlands with higher TDN and Ca were associated with increased waterfowl use, whereas chloride concentrations were negatively related (Savard et al. 1994).

Pesticide concentrations in parkland wetlands can be measured directly and may provide information on the range of impact to wetlands. Pesticide residues were measurable in $92 \%$ of wetlands investigated in a study by Anderson et al. (2002). Of all pesticides measured, glyphosate was present in the highest concentrations (Anderson et al. 2002).

Measurement of riparian zone health surrounding wetlands may also be useful in the aspen parkland. This includes parameters like riparian coverage around the wetland perimeter and width of the buffer zone. Vegetative buffers are known to protect water quality from runoff 
loading of pesticides and other chemicals from agricultural uplands (Wauchope et al. 1994, Anderson et al. 2002).

\subsection{Boreal Dry Mixedwood}

Studies of physical and chemical parameters of wetlands in Alberta's boreal dry mixed wood ecozone are very rare, and studies that have been performed focus on nutrient status (specifically P concentrations) of wetlands. Like other wetlands in the province, water chemistry parameters tend to be variable. Shallow water wetlands in the southern boreal portion of the province tend to exist as either high chlorophyll water (turbid) or low chlorophyll water (clear). However, there is a huge range of natural variation in clear and turbid lakes in the boreal dry mixedwood region of Alberta (Bayley and Prather 2003, Norlin et al. 2005). Furthermore, natural wetlands can switch from one state to another between years (Bayley et al. 2007) and even within the same season (Norlin et al. 2005).

Measurements of nutrient status of wetlands in the boreal dry mixedwood region may be difficult to implement as an indicator of wetland health as many of the wetlands are naturally phosphorus rich (Bayley and Prather 2003, Macrae et al. 2004, Mitchell and Prepas 1990). There were no significant effects of forest harvesting in uplands surrounding wetlands with respect to phosphorus levels (Macrae et al. 2004). These soils are naturally $P$ rich and the area has low soil moisture and limited runoff (Macrae et al. 2004, Devito et al. 2000, Westbrook 2000).

Because of the wide range of natural variation in the chemistry of boreal dry mixedwood ponds and the lack of studies on physical and chemical parameters, biological indicators may be more useful in this area.

\subsection{Other Regions in North America}

Studies of wetlands in other parts of North America also show a large range in the amount of nutrients, particularly phosphorus, in both the sediments and water column (Pan et al. 2000). Other water chemistry parameters such as chloride concentrations, inorganic nitrogen, phosphorus and conductivity were higher in human-impacted wetlands (Kashian and Burton 2000). In addition, pond chemistry varies seasonally (Angelibert et al. 2004) and therefore several measurements throughout the season may have to be taken. Nutrient richness in Great Lakes coastal marshes decreased with increasing forested area compared with those wetlands surrounded by urban or agricultural areas (Crosbie and Chow-Fraser 1999).

However, parameters such as soluble reactive phosphorus (SRP) and nitrate concentrations in the water column were not correlated with surrounding land use (Crosbie and Chow-Fraser 1999). In general, runoff loading, and therefore disturbance, to wetland systems was adequately predicted based on dominant land use in the watershed surrounding marshes (Rast and Lee 1983).

Chemistry of wetland sediments as well as water may be useful for indicating wetland health and response to disturbance. Nutrient richness in the sediments increases with increasing 
agricultural activity in the landscape (Crosbie and Chow-Fraser 1999), specifically phosphorus concentrations (Craft and Richardson 1993). Additionally, other landscape attributes may be useful wetland health indicators. Landscapes with numerous wetlands in close association with each other (and therefore minimal disturbance) are often considered "healthier" because they are associated with increasing vegetative species richness, most likely due to dispersal of propagules between closely associated wetlands (Matthews et al. 2005).

Physical parameters such as water depth and retention time may affect wetland health. Increased water levels (above a threshold height) results in decreased aquatic macrophytes cover (Klarer and Millie 1992). As noted previously in the disturbances section, abundant submersed aquatic macrophytes are often considered to be an indicator of increased wetland health in marshes (Lougheed and Chow-Fraser 2002, Zimmer et al. 2003). Drought and especially drainage of wetland soils can increase dissolved organic carbon (in the run-off) and dissolved organic nitrogen concentrations and increase decomposition (Qualls and Richardson 2002). Reflooding of dried wetland soils can stimulate microbial activity and often increases available $P$ and N (Corstanje and Reddy 2004). Increased N and P released may stimulate algal growth and suppress growth of submersed aquatic macrophytes.

Measurements of physical properties of wetland sediments may be useful indicators of wetland health. Healthy wetland sediments support active and diverse biological populations. Clay or silt soils are more likely to adsorb organic and trace metal contaminants (Lee et al. 1992) and may be a good indication of wetland health (these soils retain chemical compounds) (Maher et al. 1999). Furthermore, suspended solids and sediment depth are directly related to urban land use surrounding aquatic systems in some areas (Freeman and Schorr 2004).

Riparian buffer strips have been shown to be useful as an indicator of wetland health as their presence often indicates a healthier wetland (Mensing et al. 1998). Riparian areas, located immediately adjacent to aquatic systems, are generally distinguished from uplands by increased soil moisture and unique vegetation (Klapproth 2000). Riparian buffer strips can trap agricultural and/or urban contaminated runoff, sediment (Crosbie and Chow-Fraser 1999), and excess nutrients (Klapproth 2000). In the United States, forested riparian areas have been found to trap up to $90 \%$ of eroded, agriculturally derived sediments (Cooper et al. 1990). Riparian vegetation that is herbaceous may provide greater removal of sediments than woody riparian vegetation, but woody vegetation is generally more resistant to flooding. It is generally accepted that loss or destruction of riparian areas leads to decreased water quality in adjacent aquatic systems (US EPA 2002f). Therefore presence or absence of a riparian buffer as well as the relative width of the riparian buffer zone may be useful indicators of wetland health. 


\subsection{BIOLOGICAL PARAMETERS AND INDICATORS IN WETLANDS OF ALBERTA'S PRAIRIE, ASPEN PARKLAND AND BOREAL DRY MIXEDWOOD ECOZONES}

Biological indicators are often used to assess the health of aquatic ecosystems, including wetland ecosystems (US EPA 2002d). Wetlands are naturally variable geographically, hydrologically and physically, however changes and disturbances to wetland health, functions, and values are often reflected in some aspect of the biotic community (US EPA 2002d). Useful biological indicators of wetland health are those that respond predictably to anthropogenic disturbances in wetlands (Karr and Chu 1999). Commonly used biotic indicators include specific attributes of algal, macroinvertebrate, vegetation, amphibian, fish, and bird communities. Attributes of these communities include species richness, community composition, tolerant and intolerant species, and health of individuals (US EPA 2002d). In Alberta, few studies have documented biological conditions of wetlands over the natural range of disturbance and over the wide range of anthropogenic disturbances. Studies in other North American wetlands may help us find biological indicators of wetland health that may be useful for assessment in Alberta wetlands.

\subsection{Prairie}

Wetlands in the prairie pothole region of North America are more extensively studied (especially those in the United States) than other wetland complexes of the continent. As a result, information on biotic communities in prairie wetlands is available and may be useful as indicators of overall wetland health. These indicators include attributes of invertebrate, macrophyte, avian and fish communities.

\subsubsection{Invertebrates as Indicators in Prairie Wetlands}

Invertebrates, especially macroinvertebrates, are commonly sampled in prairie wetlands (US EPA 2002b). In general, invertebrate communities in the prairie region vary between years (Zimmer et al. 2000) and seasonally, both among and within wetlands in the same region (Murkin et al. 1992, Tangen et al. 2003). Changes in invertebrate communities in prairie wetlands may be the result of natural or anthropogenic disturbances. However, invertebrate communities respond most commonly to changes in wetland hydrology, water retention, water salinity and changes to the surrounding land uses (Zimmer et al. 2000). Natural wet and dry cycles in prairie wetlands may affect invertebrate community structure and abundance (Whiles and Goldowitz 2005). In relatively pristine prairie pothole wetlands of the USA, macroinvertebrate richness increased with increasing wet periods and greater water level fluctuations (Batzer et al. 2004). Further, under natural drought stresses, egg banks in the soil generally maintain invertebrate populations (Euliss and Mushet 1999). Many prairie wetlands do not support fish populations, or will alternate from fish to fishless naturally on an annual basis (Euliss and Mushet. 1999, Zimmer et al. 2001). Several studies have shown that macroinvertebrate biomass is higher in fishless prairie wetlands (Zimmer et al. 2000, Zimmer et al. 2001, Tangen et al. 2003). 
Studies of invertebrates as biological indicators in prairie wetlands are generally taxonbased, i.e., they involve measuring the biomass of certain taxa over a range of disturbances or experimental treatments (US EPA 2002b, Zimmer et al. 2001). Intensive agriculture practices surrounding wetlands can have differential effects on invertebrate communities. Soil invertebrate egg banks' species diversity and abundance is decreased in areas with intensive agriculture (Gleason et al. 2003). Taxon richness of zooplankton communities in prairie wetlands was significantly lower in agricultural sites than in non-disturbed reference sites (Dodson and Lillie 2001). Odonates (dragonflies and damselflies) may be useful as indicators of disturbance in prairie wetlands as abundance decreased in response to cattle grazing (Foote and Rice-Hornung 2005).

However, other studies did not always show a clear relationship between invertebrate community structure and disturbance. Tangen et al. (2003) did not find a strong relationship between increasing agricultural land use in prairie wetland catchments and the invertebrate community. Casey et al. (1999) found that cattle grazing intensity did not affect macroinvertebrate species richness. However, nutrient enrichment in other prairie marshes resulted in an increased abundance of macroinvertebrates but community structure was not affected (Zrum et al. 2000, Hann et al. 2001).

Variable differences in invertebrate response to disturbance may be due to high natural disturbances and resilient invertebrate taxa in prairie pothole wetlands (Tangen et al. 2003) that recover quickly from disturbances (Mayer et al. 2004). For example, after pesticide applications to prairie wetlands, invertebrate abundance declined (Zrum and Hann 2002). However effects may be short term and differ between the open water and benthic invertebrate communities (Melaas et al. 2001).

\subsubsection{Emergent and Submersed Aquatic Macrophytes as Indicators in Prairie Wetlands}

Evaluation of wetland vegetation communities may involve using a floristic quality index (FQI) which is based on the tendency of plant species to occur in a range of conditions from pristine to disturbed, and may be useful in prairie wetlands to assess wetland health (Mushet et al. 2002). Unfortunately, vegetation community composition will also vary naturally between wetland types and zones within wetland and geographic locations. Macrophyte biomass, one of the simplest parameters to measure, fluctuates widely within and among wetlands both seasonally and annually (Lillie and Evrard 1994).

In general, wetland macrophyte communities in the prairie potholes are influenced by disturbance (Zimmer et al. 2003) and can therefore be good candidates as indicators.

Macrophytes tend to exhibit lingering effects following disturbance (Galatowitsch and van der Valk 1996) allowing for a longer sampling window following a disturbance.

In prairie marshes, landscape disturbances such as agriculture and urban development coincided with reduction in native grass species and abundance, and higher proportions of introduced species (Galatowitsch et al. 1998). 
Sediment loading into prairie wetlands occurs from topsoil erosion from surrounding agricultural areas (Gleason and Euliss 1998) and resulted in decreased seedling emergence of macrophytes (Gleason et al. 2003). Further, submersed macrophyte abundance decreases with increasing turbidity in prairie pothole wetlands (Zimmer et al. 2003). Prairie wetlands with no cattle grazing pressure had higher amounts of terrestrial and emergent vegetation (Casey et al. 1999).

It is claimed that wetlands with clear water and abundant submersed aquatic vegetation (SAV) and emergent macrophytes are generally "healthier" than turbid, algal dominated wetlands (Lougheed and Chow-Fraser 2002). And in fact, there are hundreds of restoration efforts underway in the prairie region of the USA to restore submersed macrophytes to shallow open water lakes (Gleason et al. 2004). Growth of SAV is inhibited by additions of herbicide from agricultural runoff in prairie wetlands and above-ground productivity in prairie fens increases with phosphorus addition (Chapin et al. 2004). Dense stands of SAV can provide structure for invertebrates (Murkin et al. 1992) and food for waterfowl. Monotypic stands of tall hydrophytes such as cattails (Typha spp.) can result in hypoxic conditions (Murkin et al. 1992) which may affect invertebrate abundance and decrease use of the wetlands by waterfowl (Kantrud 1986). In general, Typha species are tolerant of a wide-range of conditions and are usually found in nutrient rich (Davis and van der Valk 1978, Craft and Richardson 1997), saline (Panno et al. 1999) or degraded sites (Lougheed et al. 2001).

Use of algae as bioindicators may also be useful (US EPA 2002e), however few studies were found on algal characteristics of prairie wetlands in Alberta. In general, nutrient additions to marshes significantly increase biomass of phytoplankton in the water column in prairie wetlands (Sandilands et al. 2000, Hann and Goldsborough 1997, Murkin et al. 1991). Studies in the Delta Marsh of prairie Manitoba indicate that epiphyton and metaphyton biomass increased significantly with nutrient additions (McDougal et al. 1997). Green algae proliferated following additions of inorganic nitrogen and phosphorus to prairie marshes (Hann and Goldsborough 1997). Natural water level changes influenced algal productivity in prairie wetlands as flooding of dried wetland soil and plant litter releases nutrients (Murkin et al. 1989, Goldsborough and Hann 1995).

\subsubsection{Waterfowl as Indicators in Prairie Wetlands}

Waterfowl communities and abundance may be useful as an indicator of prairie wetland health, especially since waterfowl productivity and use are one of the most important functions of wetlands in this area. Wetland birds are considered as indicator of wetland health and productivity. They can be useful because measurements do not require detailed taxonomy but abundance assessments are expensive (US EPA 2002a). In addition, wetland birds are sensitive to a variety of changes to wetland health although cause and effect can not easily be linked (US EPA 2002a).

Temporarily flooded prairie grasslands can be important avian feeding areas and support large populations of waterfowl (Paillisson and Marion 2002). There is a significant relationship between wetland area loss to agriculture and the population declines of dabbling ducks (Anas spp.) such as mallards and northern pintails (Bethke and Nudds 1995). Since the 1970's

A Review of indicators of wetland health and function in Alberta's prairie, aspen parkland and boreal dry mixed wood regions 
populations of dabbling ducks in the Canadian prairie-parkland region have declined (Caithamer et al. 1992), most likely in direct relation to habitat loss to agriculture, urbanization (Nudds and Cark 1993), and natural loss to drought (Johnson and Shaffer 1987). Greater breeding activity of waterfowl was measured in wetlands with minimal amounts of cattle grazing (Casey et al. 1999). Further dabbling duck breeding pair densities corresponded to increased macrophyte biomass but not to macroinvertebrate density (Lillie and Evrard 1994). Natural changes to prairie wetlands and annual breeding population fluctuations should be considered when estimating breeding success of waterfowl (Lillie and Evrard 1994). Droughts can lead to decreased numbers of breeding ducks in the prairie pothole region (Wilkins et al. 2002, Bethke and Nudds 1995) and during drought years breeding waterfowl may use wetlands in the aspen parkland and boreal forest rather than the prairie region (Johnson and Grier 1988, Hestbeck 1995). Deficits of duck abundance in Canadian prairie wetlands appear to be greatest in Alberta (as compared to Saskatchewan and Manitoba), presumably due to greater agricultural expansion in Alberta (Bethke and Nudds 1995). Therefore, aerial and ground surveys of duck abundance may be useful indicators of wetland health and disturbance in the prairie region, although they are highly variable on an individual lake or wetland.

Landscape characteristics may influence bird species abundance and diversity (Koopowitz et al. 1994, Vos and Stumpel 1996). The most consistent indicators of waterfowl abundance in prairie wetlands are percent of cropland and grassland; more ducks were present on grassland-dominated areas than cropland-dominated areas (Austin et al. 2001). Furthermore, total and mean avian species richness was positively correlated with area of upland buffers (Stapanian et al. 2004). There is a positive relationship between breeding duck numbers and pond densities in the prairie region (Batt et al. 1989) and between water conditions and duck numbers (Austin 2002). The percentage of wetland area covered with emergent vegetation is also a significant predictor of bird species richness (Fairbairn and Dinsmore 2001). However, bird use of wetlands may be variable depending on vegetative cover and structure and vegetative community composition (VanRees-Siewart and Dinsmore 1996). Therefore it may be useful to measure bird abundances in addition to vegetation characteristics of wetlands.

\subsubsection{Fish and Amphibian Communities as Indicators in Prairie Wetlands}

Fish communities in prairie wetlands may not be good biological indicators of disturbance, even though variability in fish populations may reflect anthropogenic activities (Hanson et al. 2005). Fish populations in the prairies are naturally variable and individual water bodies often alternate between fish and fishless (Zimmer et al. 2001) and very few pothole wetlands support permanent fish populations (Euliss et al. 1999). Wet-dry cycles also result in high variability of amphibian communities (Semlitsch et al. 1995). Hence they may not be very useful as biological indicators of anthropogenic disturbances.

\subsection{Aspen Parkland}

Few studies have been performed on biological communities in wetlands in the Aspen Parkland of Alberta. Those that have been conducted generally focus on avian, macroinvertebrate, and amphibian communities, with less information on vegetation communities. 
Benthic macroinvertebrates may be useful for assessing disturbance in aquatic systems (Casey 1995). Benthic macroinvertebrates include organisms that live at least part of their life cycle in the bottom substrate of aquatic ecosystems and include a large number of taxonomic groups that overall show a wide range of responses to water and sediment quality changes. In general, lower diversity of benthic macroinvertebrates indicates disturbance to the system (Casey 1995). Furthermore, pesticides, one of the major contaminants to wetlands in the aspen parkland of Alberta (Anderson et al. 2002), may remain persistent in aquatic benthos (Helawell 1986, White 1988) whereas they are only temporarily elevated in the water column (Zrum et al. 2000). Thus, effects of pesticide contamination may be more easily measured in aquatic benthic communities.

Studies of vegetation communities in aspen parkland wetlands are rare. However it was shown that submersed macrophytes productivity was increased but had a lower diversity in wetlands that received thermal effluent. Furthermore, thermal effluent to the wetland resulted in phytoplankton blooms (Taylor and Helwig 1995). In a separate study, parkland ponds with minimal disturbance from cattle grazing pressure had higher amounts of terrestrial and emergent vegetation (Casey et al. 1999).

There is a significant relationship between wetland area loss to agriculture and the population declines of Mallards and Northern Pintails in the aspen parkland (and prairie) regions of the province (Bethke and Nudds 1995). Since the 1970's populations of dabbling ducks in the Canadian prairie-parkland region have declined (Caithamer et al. 1992), presumably in direct relation to anthropogenic habitat loss to agriculture, urbanization (Nudds and Clark 1993), and drought (Johnson and Shaffer 1987). Furthermore, disturbance from cattle grazing decreased waterfowl breeding activity in parkland wetlands in Alberta (Casey et al. 1999). In the aspen parkland of British Columbia, abundance of dabbling ducks were positively associated with turbidity and dissolved nitrogen in the water column and negatively associated with amount of forested shoreline (Savard et al. 1994).

Use of amphibians as biological indicators of wetland health in Aspen Parkland wetlands may not be useful since serious declines in amphibian populations have been reported in the central regions of the province (Turner et al. 1987, Hamilton et al. 1998). Further many amphibian species are not present at all in several surveyed Alberta wetlands (Takats and Priestley 2002). Furthermore, deformity levels are commonly measured in several North American anuran species as a measure of disturbance, however in Alberta, wood frogs (Rana sylvatica) deformity levels are low (Eaton et al. 2004). Amphibian abundance is unaffected by disturbances to harvesting of forest buffer strips surrounding Alberta wetlands (Hannon et al. 2002).

\subsection{Boreal Dry Mixedwood}

In general, there are very few studies of wetlands in the boreal dry mixed wood of Alberta that provide sufficient analysis of ecological parameters to evaluate useful biological indicators for these sites. 
Large-sized zooplankton communities were dominant in lakes with high SAV and clear water (Norlin et al. 2005). Clear, macrophyte-dominated sites are generally thought to be healthier than turbid sites (Lougheed and Chow-Fraser 2002). Such generalization may not necessarily be true in the boreal regions of Alberta where turbid/clear differences in trophic state vary naturally (Bayley and Prather 2003 and Bayley et al. 2007).

Studies are currently underway to assess the effect of agriculture in dry boreal mixedwood wetlands. Nutrient addition increased phytoplankton biomass in boreal plain lakes of Alberta (Grant and Tonn 2002) and increased forestry and agricultural activities in the area are expected to result in increased nutrient inputs (Prepas et al. 2001). However, it may be difficult to distinguish between naturally eutrophic wetlands and anthropogenically eutrophic wetlands as ponds in Alberta's boreal plain tend to be naturally phosphorus and plankton-rich (Bayley and Prather 2003, Bayley et al. 2007, Mitchell and Prepas 1990, Norlin et al. 2005, Prepas et al. 2001).

Analysis of macroinvertebrate communities is rare in the southern boreal region of the province. It has been reported that macroinvertebrate biomass increased following disturbances by forest fires. However more detailed taxonomic studies including the relative abundance of chironomid species did not show any differences between burned and unburned reference sites (Casey 1995).

The western boreal forest is a key habitat for aquatic birds in North America (Morrison 2002) and supports an estimated 13 million breeding ducks annually (Paszkowski et al. 2004). Estimates of duck populations may be useful indicators of wetland health. Decreases in duck abundance are more likely in response to anthropogenic disturbances compared to natural disturbances as boreal systems are not as impacted by drought compared to prairie and parkland regions. However drought in the south may increase bird abundance in the boreal mixed wood region (Bethke and Nudds 1995).

Bird abundance tends to follow similar patterns to fish abundance in boreal plain lakes in Alberta (Paszkowski and Tonn 2000); although generally more birds are found in fishless lakes than in lakes with large bodied fish (Epners, 2007). In general, studies on aquatic bird communities in Alberta are poorly documented (Paszkowski and Tonn 2000) and may not necessarily follow patterns seen in other regions (Gingras and Paszkowski 1999).

Vegetation characteristics can be affected by agriculture and grazing as well as by natural fluctuations in water availability. In bog and fen wetlands, vegetation may not be a useful indicator since patterns and zonation of peatland vegetation are regulated by water availability (Whitehouse and Bayley 2005) as well as environmental conditions, (Bowles et al. 2005) including water chemistry parameters ( $\mathrm{pH}$, conductivity, and nutrient concentrations) (Bridgham et al. 1996). Many peatland lakes are isolated or buffered from agriculture and no data are available for Alberta.

Marsh wetland lakes show clear visual differences when grazed, although the studies are on-going. Previous grazing studies showed that cattle decrease vegetative biomass (Casey et al. 
1999). Therefore, care must be taken when using vegetative indicators to distinguish between natural and anthropogenic conditions.

The presence or absence of fish may not be a useful indicator of wetland health. In boreal wetlands, presence of fish may result in a lower density of breeding waterfowl (Adamus et al. 2001). However many shallow wetlands in Alberta's western boreal forest are naturally fishless (Conlon 2002) due to frequent winterkills in the shallow, hypoxic wetlands of the landscape (Danylchuk and Tonn 2003). Currently in the southern boreal part of Alberta, it appears that landscape disturbances such as forest harvesting and fires have minimal effects on fish assemblages (Tonn et al. 2003).

\subsection{Studies Based in Other Regions of North America and Potential Biological Indicators of Wetland Health in Alberta}

Extensive studies on wetlands in other regions of North America may reveal useful biological indicators of wetland health for Alberta's prairie, parkland and boreal dry mixedwood regions. These potential indicators include characteristics of algae, invertebrates, macrophytic vegetation and amphibian communities.

\subsubsection{Algae}

Algae have been recommended as bioindicators in aquatic systems (McCormick and Stevenson 1998, Stevenson et al. 2001, Lowe and Pan 1996). Sediment re-suspension increases algal productivity (Schallenberg and Burns 2004). Diversity and species richness of algae communities decrease as a result of increasing salinity (Floder and Burns 2004). Algal communities respond predictably to nutrient enrichment with increasing cyanobacteria corresponding to increasing phosphorus (Pan et al. 2000). Nutrient enrichment generally results in increased algal biomass in the water column (Best et al. 1984, Ozimek et al. 1991, McNair and Chow-Fraser 2003, Rejmankova and Komarkova 2005). Algal biomass and diversity are also positively correlated with nutrient ( $\mathrm{N}$ and $\mathrm{P}$ ) concentrations in sediments (Zheng et al. 2004). McNair and Chow-Fraser (2003) recommend use of benthic and planktonic algal biomass as an indicator of wetland water quality degradation because biomass is strongly positively correlated with water TP and turbidity as well as N (Rejmankova and Komarkova 2005).

Algal species composition is more sensitive to phosphorus loading than algal biomass in wetlands (Pan et al. 2000) and lakes (Schindler 1987). Species-level indicators are problematic because they require taxonomic skills (Johnson 1998). Algal samples are very easy to collect, but biomass and community composition varies among wetlands (Chow-Fraser 1999, Mayer and Galatowitsch 1999) and seasons (Zheng et al. 2004). Where algal biomass is a useful indicator, chlorophyll concentrations are often used as a surrogate of algal biomass. However, this approach may be problematic because chlorophyll concentrations are variable in lakes and may not necessarily be a good representation of algal biomass (LaBaugh 1995). 


\subsubsection{Invertebrates}

Aquatic invertebrates, especially macroinvertebrates are frequently used as bioindicators of water quality (Rosenberg and Resh 1993, Karr and Chu 1997, Burton et al. 1999, King et al. 2000, Rader et al. 2001). Smaller aquatic invertebrates or zooplankton are less commonly used as indicators in wetlands. Zooplankton species composition and abundance is highly variable both within and among wetlands and varies seasonally. Lougheed and Chow-Fraser (1998) developed a good metric of wetland health for the Great Lakes wetlands using zooplankton. Because those sites were connected to the Great Lakes they contained fish and more stable water levels. Hence the zooplankton responses were primarily related to nutrients and contaminants from runoff. Without Alberta, or at least prairie-specific data, one cannot be sure if zooplankton indices would be useful.

Benthic macroinvertebrates are good indicators because of their close association with sediments and the water column (Pettigrove and Hoffmann 2005). One of the most commonly used biological indicators of aquatic health are benthic Chironomidae (or midge larvae) communities. Different chironomid species respond differently to sediment pollution (Pettigrove and Hoffmann 2005) and in general, chironomids are tolerant of disturbance and are found in degraded sites whereas they are less abundant in "healthier" oligotrophic sites (Hart and Lovvorn 2005). Whether they would be useful in Alberta's naturally eutrophic wetlands is unknown.

In general, chironomid abundance in wetlands increases with increasing nutrients (Steinman et al. 2003). In Lake Huron wetlands, human impacted sites had fewer insect species and increased chironomid abundance and biomass (Kashian and Burton 2000). Furthermore, chironomid abundance and biomass as well as leech biomass was higher in devegetated (degraded) plots (Flinn et al. 2005). In Minnesota, wetland impairment resulted in the increase in abundance of chironomids, with very few intolerant taxa being observed at the most impaired sites (Adamus et al. 2001).

Other authors also find that Chironomidae can be used as indicators of wetland disturbance (Plafkin et al. 1989, Karr 1993). King and Richardson (2002) found that using chironomids as indicators was best if identified to species level. Other studies indicated that identification to family and using general abundance is useful (Steinman et al. 2003). Again, it is unknown if these studies are applicable to the different wetland systems that occur in Alberta.

Species richness and diversity of other aquatic invertebrate communities may be useful as indicators of wetland health. Richness and diversity of invertebrates may decrease (Steinman et al. 2003) or be unaffected (McCormick and Stevenson 1998) by increasing phosphorus and nutrient concentrations in southern marsh wetlands. Other studies found that macroinvertebrate communities could be a valuable tool to assess the ecological status of wetlands as invertebrate taxa richness declines in response to increasing levels of degradation (Barbour et al. 1997). Macroinvertebrate communities may be impacted by land use in the watershed (Freeman and Schorr 2004) and richness decreases in wetlands surrounded by agriculture (Hall et al. 2004).

Lower biomass and abundance of zooplankton in coastal Great Lakes marshes (Lougheed and Chow-Fraser 1998) and lower diversity of macroinvertebrates (Spieles and Mitsch 2000) 
was measured in turbid and eutrophic open water riverine wetlands. Within wetlands, higher diversity of macroinvertebrates was measured in areas with increased vegetative cover (De Szalay and Resh 2000). Emergent wetland areas contained higher macroinvertebrate richness and diversity than open water wetlands (Balcombe et al. 2005) because of increased food resources and structure (Carpenter and Lodge 1986). However too much emergent vegetation may decrease dissolved oxygen levels and result in lower invertebrate biomass (Balcombe et al. 2005).

In general, invertebrate communities, especially macroinvertebrates, may be useful indicators of wetland health. Invertebrate communities vary within the wetland and seasonally (MacKenzie et al. 2004) and are often affected by natural fluctuations in wetland hydrology, including duration and frequency of flooding (de Szalay et al. 1999).

\subsubsection{Vegetation}

Use of vegetation as indicators of wetland health is becoming common in several areas of the United States (US EPA 2002f). Turbid, nutrient rich wetlands are generally characterized by emergent vegetation whereas other wetlands are generally clear with lower nutrient levels and dense SAV communities (Lougheed et al. 2001). Increase in eutrophication and/or algal biomass results in decreased SAV biomass and cover (Best et al. 1984, Ozimek et al.1991, McNair and Chow-Fraser 2003).

Typha species (cattails) grow in a wide range of conditions (Lougheed et al. 2001). Cattail monocultures are common in sites with high phosphorus levels (McCormick and Stevenson 1998, Rutchey and Vilchek 1999) and growth of cattails is positively correlated with soil and water TP (Craft and Richardson 1997). Migratory bird use of wetlands decreases in cattail-dominated wetlands, as does macroinvertebrate density (Kostecke et al. 2005).

Floristic quality indices (plants most likely to be found in 'pristine' wetlands are assigned higher numbers than those that occur in disturbed areas) may also be useful in indicating wetland health (Matthews et al. 2005). Floristic quality was negatively correlated with disturbance of a wetland and with distance to neighbouring wetland sites (Lopez and Fennessy 2002). In addition, floristic quality decreased for wetlands surrounded by agricultural or urban land use (Lopez and Fennessy 2002).

In Minnesota, increasing levels of disturbance resulted in fewer intolerant (more sensitive) plant species such as iris (Iris spp.) and common bladderwort (Utricularia vulgaris) and increased coverage of tolerant species, such as duckweed (Lemna spp.) and cattails (Typha spp.) (Adamus et al. 2001). In Alberta many (but not all) natural wetlands contain cattails and Lemna spp.(Bayley, unpublished data), but also a wide range of other less common emergent and submerged vegetation. Macrophytes may be the most promising parameter for Alberta wetlands because plants are the base of the food chain, respond dramatically to disturbance (Brown and Batzen 2001) and strongly influence higher trophic levels (Hunter and Price 1992). 


\subsubsection{Amphibians}

Amphibians and macroinvertebrates may respond similarly to differences in wetland characteristics and assemblages and differ depending on water permanence within the wetlands (Babbitt et al. 2003). Amphibian abundance decreases and fish abundance increases as the proportion of open water to rangeland increases (Mensing et al. 1998). Salamanders were virtually eliminated in wetlands treated with insecticides. Herbicides had negative effects on amphibian body size and development (Boone and James 2003). Amphibian species richness was positively correlated with wetland area and forest cover in Ontario wetlands, and negatively correlated with road density and N concentrations (Houlahan and Findlay 2003).

More investigations are required to determine the best biological indicators of wetland health (US EPA 2002d). Many wetland biota can tolerate stressful conditions produced by natural disturbances as well as anthropogenic disturbances (Euliss et al. 1999, Higgins and Merritt 1999). It is therefore difficult to differentiate between biotic effects that are natural compared to human-induced. Preliminary studies in wetlands of the USA have shown that using a suite of biological indicators (especially macroinvertebrates and plants) together provides increased power of bioassessments (Adamus et al. 2001).

Some biological indicators/assemblages may be useful in some wetlands but not in others, depending on wetland class and geographic location (US EPA 2002d). Therefore it is recommended that several wetlands be sampled when evaluating usefulness of indicators and wetlands of the same region and class (i.e., fen, marsh, open water) are compared with one another. 


\subsection{SUMMARY}

Wetlands cover approximately $21 \%$ of the land area of the province of Alberta (NWWG 1988). These unique ecosystems represent a transitional area between open water and upland, and because of their unique features are comprised of a wide mosaic of habitats (Rose and Crumpton 1996). Wetlands in Alberta provide a variety of valuable biological and economic functions (DUC 2004). Many of these wetlands have been negatively impacted by anthropogenic disturbances (Turner et al. 1987) which in turn affects the health and function of the wetlands. In order to assess the health of wetland ecosystems in Alberta, particularly in the prairie, aspen parkland and boreal dry mixedwood regions, we recommended that ecological indicators be used to assess wetland structure and function, and hence wetland "health". Good indicators of a healthy or, alternatively, a degraded/impacted wetland, have been measured in a variety of wetlands in North American and have been shown to respond in a predictable manner to increasing levels of disturbance (Karr and Chu 1999). In general, indicators of wetland health may be biological, physical or chemical in nature.

Despite the large amount of research on various wetlands in North America, information on general ecology and characteristics of wetlands in Alberta is limited, especially in the aspen parkland and boreal dry mixedwood ecozones of the province. Even research on prairie wetlands is limited in Alberta, although studies in Manitoba prairie wetlands (specifically the Delta Marsh) are common and studies from US prairie pothole wetlands are abundant. It must be recognized that Stewart and Kantrud's (1971) prairie wetland classification system encompasses seven types of wetlands (ephemeral, temporary, seasonal, semi-permanent, permanent, alkali and fen ponds). Specific studies on each of these types are rare in Canada, especially as they relate to ecological indicators.

There has been partial mapping of wetlands, wetland loss and wetland types for the prairie, aspen parkland, and boreal dry mixedwood ecozones of Alberta. Wetland mapping has been done for selected regions, but only regional comprehensive wetland inventories exist. Hence, information on wetland loss and destruction, extent of disturbance to wetlands and the impacts of these disturbances on wetland health and function is minimal within the province of Alberta. Without this information it is difficult to make inferences about good potential indicators of wetland health in the province, especially given the wide range of natural variation within and among wetlands. To determine which indicators best characterize the health of the diverse wetlands of Alberta, we need to have information on wetlands under a wide range of natural and anthropogenic disturbances.

Based on the scientific literature from studies on Alberta wetlands as well as other North American wetlands, there does not seem to be any single indicator or class of indicators which will be the most useful to assess wetland health and function. It appears that some indicators are useful in one context, one in another and that it would be best to develop an integrated index of ecological integrity using a suite of indicators. Biological indicators appear to be the most useful tool in some wetlands to assess wetland health and function, as opposed to physical and chemical indicators. In other situations, physical and chemical indicators may be more useful, for example if one wants to determine concentrations or inputs of specific contaminants such as pesticides or metals in a given group of wetlands. In many situations, total phosphorus concentrations in the 
water column are often used as a measure of trophic status in aquatic systems. However in Alberta, total phosphorus in the water is generally very high and many wetlands are reported as eutrophic to hypereutrophic based on phosphorus levels (Bayley and Prather, 2003, Casey et al. 1999, Prepas et al. 2001). Even wetlands in undisturbed watersheds can have very high concentrations of TP and other nutrients. Hence chemical indicators have to be combined with other indicators to distinguish anthropogenic disturbance from natural variability (Bayley unpublished).

Biological indicators presumably respond in a more predictable manner than chemical or physical indicators to disturbance. Also, biological communities in wetlands with a high proportion of degraded land uses (e.g., urban, agricultural) in the watersheds can be assumed to be disturbed (US EPA 2002d).

Measuring several biological indicators may be more useful in assessing wetland health than just measuring one (Adamus et al. 2001) especially given the high range of natural variation in relatively pristine wetlands (US EPA 2002c,d). Furthermore, certain indicators may be more useful in one class of wetland than in another (US EPA 2002c).

\subsection{Issues to Consider When Developing Indicators}

It is clear that an index of biotic integrity can be developed for a given class or type of wetlands in the different ecozones of Alberta. There are a number of issues that should be considered in the development processes. These include differences in wetland zones, differences across the growing season, differences in wet and dry years as well as a host of other factors that may affect the successful development of an index of biotic integrity. To account for all of these sources of variation, there is a need for consistency and standardization with respect to study design, timing of sample collection and sampling methods and data analysis.

One may want to sample indicators in different vegetation zones since there are so many naturally different habitats within a given wetland (van der Valk 2005) and indicators are likely to change depending on the vegetative zone. For example, open water habitats will be naturally different from an adjacent marsh fringe habitat and a surrounding riparian buffer habitat. However all three of these areas will be located within the same wetland. In such cases, as long as there is consistency between wetlands (e.g., only sampling open water) or all vegetation zones are measured, discrepancies shouldn't arise. In addition, sampling of various indicators can take place at the same time. For example, a helicopter survey of ponds could simultaneously assess bird abundance, SAV abundance, extent of riparian areas and surrounding watershed land use. On-site surveys could assess water chemistry parameters such as turbidity and nutrient concentrations as well as vegetation characteristics (e.g., presence of native and introduced species).

A study measuring these indicators in wetlands of Alberta's prairie, aspen parkland and boreal dry mixedwood region would be useful in wetlands across a range of disturbance. This is difficult since the majority of wetlands in the prairie and parkland regions have been anthropogenically impacted. Despite this, a range of disturbances exists, from minimally impacted to heavily impacted. Further, wetlands should be classified to make sampling and 
indicator development meaningful. One set of indicators will not be useful for all wetland types but must be specific to the wetlands class/type. In other words, wetland health indicators are specific to a given wetland type (e.g., indicators for rich fens may not be suitable for permanent prairie marshes). In addition, wetland restoration success may be evaluated by comparing these sites to natural analogs of relatively undisturbed, natural systems. It is necessary to identify the type of wetland that restoration is attempting to achieve, the most suitable indicators for natural wetlands within the same area, and compare health indicators of restored wetlands to the range of variability observed in natural wetlands.

The number of sites selected for the indicator study should be sufficient to show a wide range of disturbance. Care should be taken to ensure that the study encompasses the same class of wetland to try to reduce the range of natural variation. Several studies will be needed to compare indicators across wetland classes. For example, prairie wetlands can encompass seven classes (e.g. Stewart and Kantrud 1971) which can be further complicated by transition of one wetland class to another or natural wet/dry cycles (van der Valk and Davis 1978). In the aspen parkland region marshes (semi permanent and permanent) and fens are common, where fens can range from poor to extreme rich (expressed in differences in species assemblages). In the boreal dry mixedwood region marshes, non forested fens, forested fens, swamps and bogs are present and each of these classes should be represented in an indicator pilot study. In some cases, wetland classes can be combined in pilot studies if there are numerous wetlands in transition between one class and another.

Despite the complexity of wetlands there are numerous successful studies that developed an index of biotic integrity for wetlands and these IBIs are used in management (Brown and Batzar 2001).

\subsection{Potential Physical and Chemical Indicators}

\subsubsection{Prairie}

Surface water nutrients may reflect inputs of nutrients from surrounding wetlands in some instances (Casey et al. 1999). Caution should be taken due to the wide range of variability that occurs among and within wetlands (White et al. 2000, White and Bayley 2001) and the fact that most wetlands in this region are already eutrophic (Casey et al. 1999).

Water chemistry is quite variable in Alberta's prairie wetlands (Prepas et al. 2001, White and Bayley 2001) yet it can provide an overall general picture of surface water quality. Measurements of basic water chemistry parameters may be useful to indicate wetland health. In Canadian prairie wetlands, turbidity was attributed to increased algal concentrations as well as increased sediment suspension in the water column (Jackson 2003), both of which are attributed to agricultural activities in the watershed.

Extent of riparian buffer area surrounding prairie wetlands may also be a good indicator as increasing width and amount of riparian areas edging is associated with increased "health" in the form of nutrient retention (Klapproth 2000) as well as increasing bird species richness (Naugle et al. 1999). 


\subsubsection{Aspen Parkland}

In general, wetlands in Alberta's aspen parkland are mesotrophic to hypereutrophic (Anderson et al. 2002, Casey et al. 1999) based on phosphorus concentrations. Therefore, measurements of TP concentrations may not be useful indicators because a natural gradient of low $\mathrm{P}$ to high $\mathrm{P}$ associated with disturbance does not seem to exist. In wetlands of the aspen parkland of British Columbia, total dissolved nitrogen and calcium in surface water were good indicators of wetland health in that wetlands with higher dissolved nitrogen and calcium were associated with "healthier" wetlands that had increased waterfowl use, whereas chloride concentrations were negatively related (Savard et al. 1994). Measurements of dissolved nitrogen and calcium may also be useful indicators of wetland health in Alberta's parkland region.

Larger extent and width of riparian buffers surrounding wetlands may also be useful as indicators of a "healthier" wetland. In this area of the province, riparian areas are known to protect water quality from runoff loading of pesticides and other chemicals from agricultural uplands (Wauchope et al. 1994, Anderson et al. 2002).

\subsubsection{Boreal Dry Mixedwood}

There is a large range of natural variation in the water chemistry of wetlands in the boreal dry mixedwood region of Alberta, which alternates between clear and turbid states (Bayley and Prather 2003, Bayley et al. 2007 and Norlin et al. 2005). Measurements of nutrient status may be difficult for use as an indicator because many wetlands are naturally phosphorus rich (Bayley and Prather 2003, Macrae et al. 2004, Mitchell and Prepas 1990) and disturbance to the surrounding areas does not necessarily affect wetland nutrient concentrations (Macrae et al. 2004). Instead, measurements of physical variables may prove to be more useful in the boreal dry mixedwood. Physical alterations such as extent of agricultural activity in the watershed, width of riparian buffer, fragmentation of the surrounding wetlands as well as unnatural drainage or ditching that is visible within the wetland is often assumed to cause wetland disturbance and result in poorer wetland "health" (US EPA 2002c).

\subsection{Potential Biological Indicators}

\subsubsection{Prairie}

Invertebrate communities in prairie wetlands are variable depending on year (Zimmer et al. 2000), season (Murkin et al. 1992), natural or anthropogenic disturbances, wet/dry cycles (Whiles and Goldowitz 2005), and presence or absence of fish populations (Zimmer et al. 2001). However, invertebrate egg banks may be useful indicators because diversity and abundance decreases with increasing agricultural usage (Gleason et al. 2003). Zooplankton species richness may also be useful as species richness decreases with increasing agricultural activity (Dodson and Lillie 2001). Measuring only Odonates (dragonflies and damselflies) may be a less complicated approach since they decrease in response to disturbance (Foote and Rice-Hornung 2005). However, it is not known how representative this study is for the entire region. Use of floristic quality indices (FQIs) have proven to be useful to assess ecosystem heath and may be useful in prairie wetlands (Mushet et al. 2002). For example, native grass species are associated

A Review of indicators of wetland health and function in Alberta's prairie, aspen parkland and boreal 46 dry mixed wood regions 
with "healthier" wetlands whereas disturbed wetlands have a higher proportion of introduced species (Galatowitsch et al. 1998). Care must be taken since vegetation communities are naturally quite different between different wetland classes and vegetation zones (van der Valk 2000, Murkin et al. 2000).

Presence and abundance of submersed aquatic vegetation (SAV) may indicate healthier prairie wetlands. These vegetative communities are often associated with healthy marshes in the Great Lakes region (Lougheed and Chow-Fraser 2002). Growth of SAV is inhibited by sedimentation (Zimmer et al. 2003) as well as by additions of herbicides (Chapin et al. 2004), both of which are prevalent in the prairies in wetlands surrounded by agriculture.

Presence of dense monotypic stands of cattails (Typha spp.) may be indicative of unhealthy wetlands since they are tolerant of hypoxic (Murkin et al. 1992) and nutrient-rich conditions (Davis and van der Valk 1983) and generally degraded sites (Lougheed et al. 2001). However, Typha monocultures can also naturally exist.

Measurements of algal biomass or chlorophyll $a$ concentrations may be useful indicators of prairie wetland health since nutrient addition (e.g., from agricultural activities) result in increased algal biomass (Sandilands et al. 2000, Hann and Goldsborough 1997, McDougal et al. 1997). In Saskatchewan prairie lakes, fossil (paleolimnological) analysis indicated that agriculture and urbanization led to an increased proportion of cyanobacteria in the phytoplankton community (Hall et al. 1999).

Waterfowl abundance may also be useful indicators of prairie wetland health since breeding activity increases in least-disturbed sites (Casey et al. 1999) and duck abundance decreases in areas impacted by agriculture. However changes to duck populations may also be due to natural disturbances such as drought (Bethke and Nudds 1995). Further, waterfowl abundance on individual lakes varies between years. Overall waterfowl abundance may not be a useful indicator for individual lakes or waterbodies but useful in a regional context or in conjunction with other indicators in the development of an index of wetland health.

\subsubsection{Aspen Parkland}

Benthic macroinvertebrates may be useful to assess disturbances to aquatic systems in Alberta's aspen parkland (Casey 1995). In general, lower abundance of benthic macroinvertebrates indicates an "unhealthy" system (Casey 1995). Given the variability in benthic macro-invertebrates between open water zones, submersed vegetation and emergent vegetation zones, it is not a "simple" indicator.

Perhaps the most documented biological parameter in the aspen parkland is the waterfowl community and may be the best indicator of wetland health in the region. Declines in waterfowl abundance are attributed to landscape disturbance (Nudds and Clark 1993, Savard et al. 1994) as well as grazing disturbances (Casey et al. 1999). Again, use of waterfowl abundance or species characteristics as an indicator for a specific lake has limitations as indicated above. 


\subsubsection{Boreal Dry Mixedwood}

Due to lack of data, we are not able to recommend indicators for wetlands in the boreal dry mixedwood region of Alberta. Studies in this region have been limited and the range of natural variability in the richness gradient of marsh, swamp, bog, and fen wetlands in the boreal dry mixedwood region of the province have not been quantified to date.

Waterfowl abundance may potentially be useful as a biological indicator in this region since studies of other biological communities are rare. Decreases in duck abundance in this region are more likely to be in response to anthropogenic changes since drought is not as common as it is in the prairie and parkland regions (Bethke and Nudds 1995). However waterfowl abundance can also be influenced by regional climate, especially drought in the prairies which causes birds to fly further north.

Ponds in Alberta's boreal plain tend to be naturally phosphorus- and plankton-rich (Mitchell and Prepas 1990, Bayley and Prather 2003, Norlin et al. 2005, Prepas et al. 2001), however nutrient addition increases phytoplankton biomass in these systems (Grant and Tonn 2002). Increasing total phosphorus is correlated with increasing proportions of cyanobacteria (Kotak et al. 2000) and therefore measuring algal biomass and/or community composition may be useful indicators of wetland health. However, research is limited across the large range of conditions.

In general, several studies on wetlands in Alberta and North America have documented specific physical, chemical and biological characteristics of these sites (Table 6); each of these characteristics is a potential indicator of wetland health. Based on the primary literature, some of these characteristics appear to respond in a predictable manner to disturbance and therefore are identified as potentially good indicators of wetland health in Alberta wetlands (Table 7). 


\subsection{RECOMMENDED APPROACH}

Overall, numerous indicators should be investigated in each of the wetland types, but funding for such studies is unlikely in the near future. Instead, we recommend that macrophytic vegetation abundance and species composition, macroinvertebrate abundance and diversity, and water quality (nutrients) parameters to be measured in marshes in an ecozone that is facing imminent development pressure. The best candidate areas are the boreal transition zone and aspen parkland ecozones. These are the regions where natural wetlands still exist as well as a gradient of disturbed wetlands. These are also the regions where the Alberta government has the opportunity to utilize an index of biotic integrity in their management of active restoration efforts.

The US EPA (2002c) cautions that only about $1 / 3$ of "potential" indicators identified will actually be useful indicators of wetland health. Therefore several potential indicators, if not all potential indicators, should be measured to determine which respond best and most predictably along a disturbance gradient. It is further recommended that several indicators within a wetland system be combined to form a multimetric index of the overall health or condition of a wetland site (Figure 3).

Numerous studies in the US have successfully developed IBIs for management purposes. The various indicators (macroinvertebrates, birds, vegetation, algae, etc.) may respond to different stressors in different ways. The studies show that many of the indicators reviewed here are useful, but that macrophytic vegetation and macroinvertebrates appear to have the greatest number of useful attributes to distinguish between degraded and undisturbed wetlands (Rader et al. 2001). 
Table 6 Summary of physical, chemical and biological attributes measured in wetlands in the Prairie region of North America and Canada's (mostly Alberta) Aspen Parkland and Boreal Dry Mixedwood regions, as well as attributes commonly measured in other North American wetland systems.

\begin{tabular}{|c|c|c|}
\hline Region & $\begin{array}{l}\text { Chemical/Physical } \\
\text { Indicators }\end{array}$ & Biological Indicators \\
\hline Prairie & $\begin{array}{l}\text { - TP } \\
\text { - TN } \\
\text { - Inorganic N } \\
\text { - Turbidity } \\
\text { - Dissolved oxygen } \\
\text { - Water depth } \\
\text { - Surface area } \\
\text { - Width of riparian area } \\
\text { - Proportion of agriculture } \\
\text { in landscape } \\
\text { - Toxicant concentrations }\end{array}$ & $\begin{array}{l}\text { - Macroinvertebrate and } \\
\text { zooplankton community } \\
\text { structure } \\
\text { - Invertebrate } \\
\text { biomass/abundance } \\
\text { - Invertebrate species } \\
\text { richness } \\
\text { - Invertebrate egg bank } \\
\text { diversity } \\
\text { - Benthic } \\
\text { macroinvertebrate } \\
\text { abundance } \\
\text { - Vegetation composition } \\
\text { - Macrophyte biomass } \\
\text { (emergent and SAV) } \\
\text { - Presence of introduced } \\
\text { plant species } \\
\text { - Monotypic cattail stands } \\
\text { - Algal biomass } \\
\text { - Waterfowl abundance } \\
\text { - Breeding pair densities } \\
\text { of waterfowl } \\
\text { - Presence/absence of fish }\end{array}$ \\
\hline Aspen Parkland & $\begin{array}{l}\text { - TP } \\
\text { - Inorganic N } \\
\text { - TDN } \\
\text { - Calcium } \\
\text { - Chloride } \\
\text { - Pesticide concentrations } \\
\text { - Width of riparian zone }\end{array}$ & $\begin{array}{l}\text { - Macroinvertebrate } \\
\text { species richness } \\
\text { - Macroinvertebrate } \\
\text { abundance and biomass } \\
\text { - Benthic } \\
\text { macroinvertebrate } \\
\text { abundance and } \\
\text { composition } \\
\text { - Productivity of SAV } \\
\text { - Diversity of SAV } \\
\text { - Algal biomass } \\
\text { - Emergent macrophyte } \\
\text { biomass } \\
\text { - Waterfowl abundance }\end{array}$ \\
\hline
\end{tabular}

A Review of indicators of wetland health and function in Alberta's prairie, aspen parkland and boreal 50 dry mixed wood regions 


\begin{tabular}{|c|c|c|}
\hline & & $\begin{array}{l}\text { - Waterfowl breeding } \\
\text { pairs } \\
\text { - Amphibian abundance } \\
\text { - Amphibian deformity } \\
\text { levels }\end{array}$ \\
\hline Boreal Dry Mixedwood & $\begin{array}{l}\text { - Turbidity } \\
\text { - TP } \\
\text { - Upland disturbances } \\
\text { (harvesting) }\end{array}$ & $\begin{array}{l}\text { - Zooplankton } \\
\text { communities } \\
\text { - SAV abundance } \\
\text { - Chlorophyll } \\
\text { concentrations } \\
\text { - Macroinvertebrate } \\
\text { biomass } \\
\text { - Waterfowl (duck) } \\
\text { abundance } \\
\text { - Vegetation communities } \\
\text { - Presence/absence of fish }\end{array}$ \\
\hline Other Regions & $\begin{array}{l}\text { - } \text { TP } \\
\text { - } \text { Conductivity } \\
\text { - Forested area in } \\
\text { watershed } \\
\text { - SRP } \\
\text { - Inorganic N } \\
\text { - Sediment nutrients } \\
\text { - Water levels } \\
\text { - Decomposition rates } \\
\text { - Soil properties } \\
\text { - Width of riparian buffers }\end{array}$ & $\begin{array}{l}\text { - Algal biomass } \\
\text { - Diversity and species } \\
\text { richness of Algae } \\
\text { - Proportion of } \\
\text { cyanobacteria } \\
\text { - Proportion of } \\
\text { Chironomidae in benthic } \\
\text { macroinvertebrate } \\
\text { assemblages } \\
\text { - Biomass of leeches } \\
\text { - Invertebrate richness and } \\
\text { diversity } \\
\text { - Emergent vegetation } \\
\text { - biomass } \\
\text { - SAV biomass and cover } \\
\text { - } \text { Biomass of cattails } \\
\text { - Amphic quality } \\
\text { Ampibian richness }\end{array}$ \\
\hline
\end{tabular}


Table 7 Potential indicators in the primary literature from studies in the Prairie region of North America, the Aspen Parkland region of Alberta and British Columbia, and the Boreal Dry Mixedwood region of Alberta. These indicators were successful in identifying some aspect of wetland "health", i.e. they appeared to respond in a predictable manner to disturbance.

\begin{tabular}{|c|c|c|}
\hline Region & $\begin{array}{l}\text { Chemical/Physical } \\
\text { Indicators }\end{array}$ & Biological Indicators \\
\hline Prairie & $\begin{array}{l}\text { - Surface water } \mathrm{N} \text { and } \mathrm{P} \\
\text { concentrations } \\
\text { - Turbidity } \\
\text { - Width and extent of } \\
\text { riparian buffer areas }\end{array}$ & 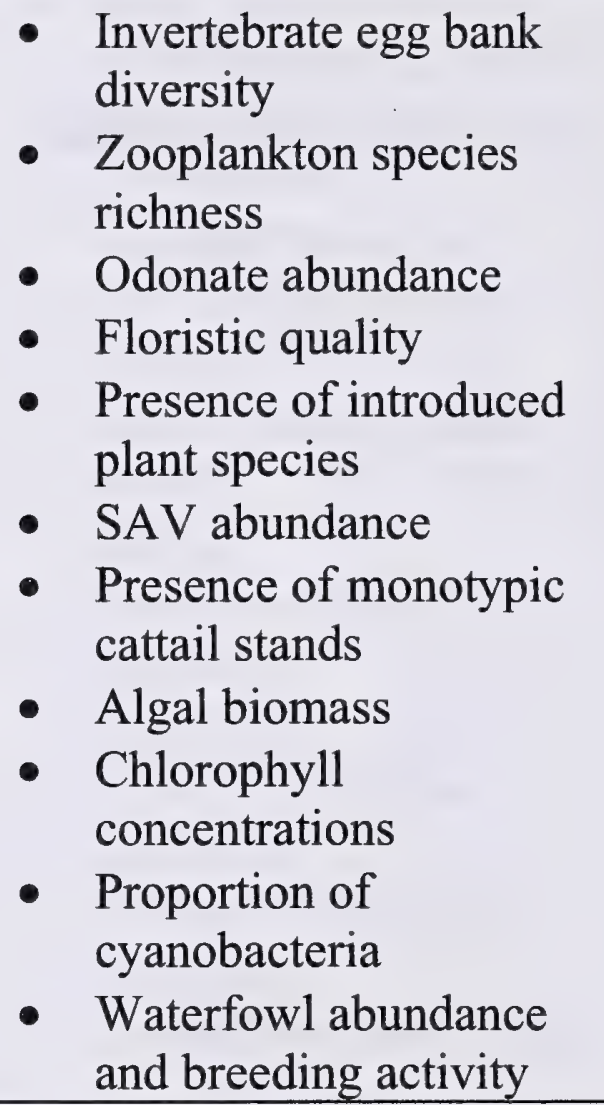 \\
\hline Aspen Parkland & $\begin{array}{l}\text { - TDN } \\
\text { - Calcium concentrations } \\
\text { - Extent of riparian } \\
\text { buffers }\end{array}$ & $\begin{array}{l}\text { Benthic } \\
\text { macroinvertebrate } \\
\text { abundance }\end{array}$ \\
\hline Boreal Dry Mixedwood & $\begin{array}{l}\text { Extent of agricultural or } \\
\text { forested areas in the } \\
\text { watershed } \\
\text { - Fragmentation of } \\
\text { surrounding watersheds } \\
\text { - Extent of riparian buffer } \\
\text { area }\end{array}$ & $\begin{array}{l}\text { - Unknown due to lack of } \\
\text { baseline data } \\
\text { - Potentially waterfowl } \\
\text { abundance and algal } \\
\text { biomass and community } \\
\text { composition }\end{array}$ \\
\hline
\end{tabular}


Goal:

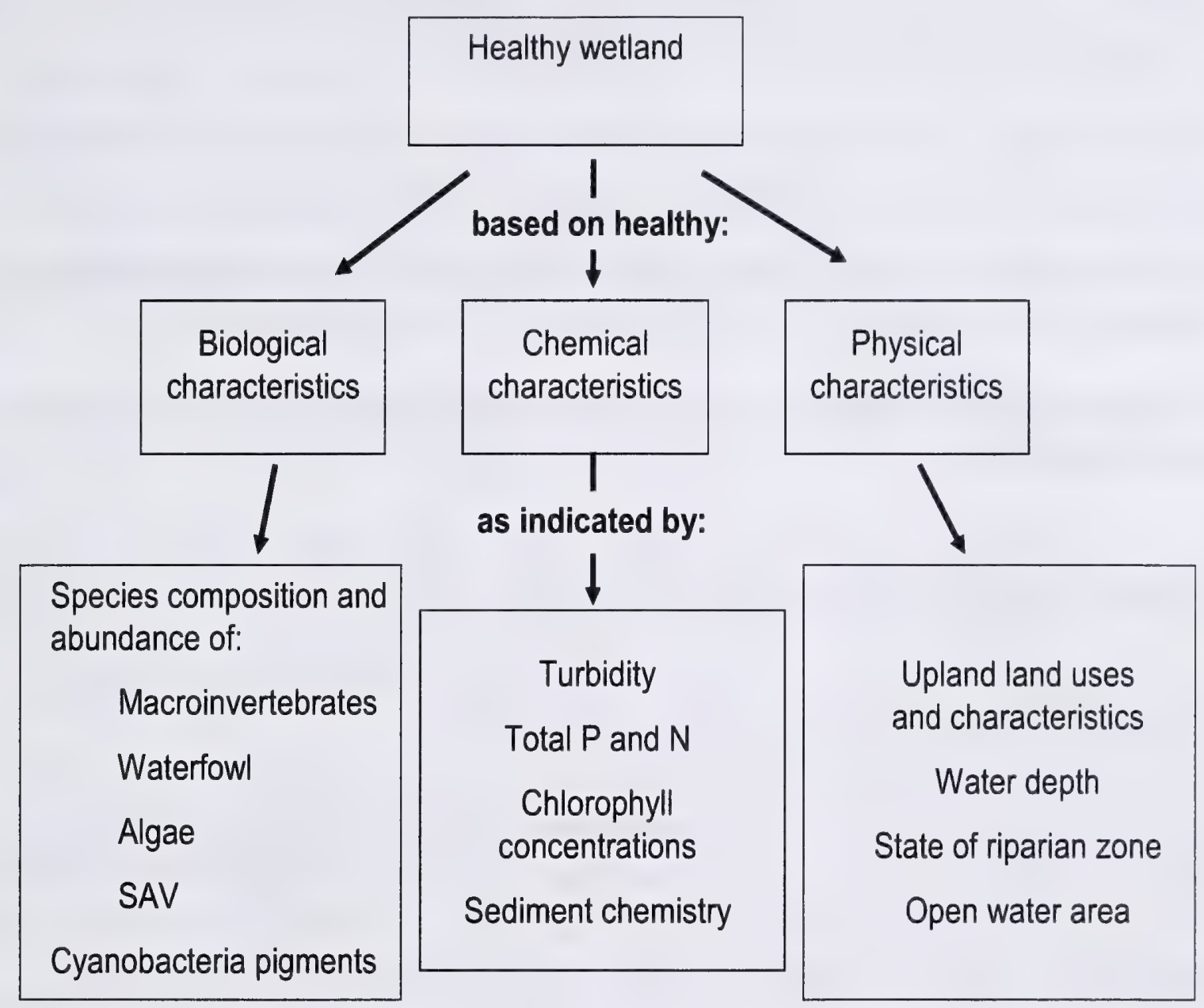

Figure 3 Suite of indicators potentially useful for determining wetland health in Alberta's Prairie, Aspen Parkland and Boreal Dry Mixedwood regions (adapted from Jacques Whitford Inc. 2005)

A Review of indicators of wetland health and function in Alberta's prairie, aspen parkland and boreal 53 dry mixed wood regions 


\subsection{LITERATURE CITED}

Adamus, P., T.J. Danielson, and A. Gonyaw. 2001. Indicators for Monitoring Biological Integrity of Inland, Freshwater Wetlands: A Survey of North American Technical Literature (1990-2000). US Environmental Protection Agency, Office of Water. Office of Wetlands, Oceans and Watersheds, Washington DC

Adamus, P.R. 1992. Choices in monitoring wetlands. In: D.H. McKenzie, D.E. Hyatt, and V.J. McDonald. Ecological Indicators. Elsevier Applied Science, New York, NY. pp. 571-592

Alberta Environmental Protection (AEP). 1999. Surface water quality guidelines for use in Alberta. Environmental service and Natural Resource Service.

Alberta Fish and Wildlife. 1991. The status of Alberta wildlife. Alberta Fish and Wildlife, Edmonton, $\mathrm{AB}$.

Amon, J. P., C. A. Thompson, Q. J. Carpenter, and J. Miner. 2002. Temperate zone fens of the glaciated midwestern USA. Wetlands 22:301-317.

Anderson, D.J., and B. Vondracek. 1999. Insects as indicators of land use in three ecozones in the prairie pothole region. Wetlands 19: 648-644.

Anderson, A., G. Byrtus, J. Thompson, D. Humphries, B. Hill, and M. Bilyk. 2002. Baseline pesticide data for semi-permanent wetlands in the aspen parkland of Alberta. Alberta Environment Water Research User Group, Alberta Environment Ecosystem User Group and Alberta North American Waterfowl Management Plan Partnership.

Angelibert, S., P. Marty, R. Cereghino, and N. Giani. 2004. Seasonal variations in the physical and chemical characteristics of ponds: implications for biodiversity conservation. Aquatic conservation-marine and freshwater ecosystems 14: 439-456.

Archer, S. and F. E. Smeins. 1991. Ecosystem-level processes. Pages 109-140. In R. K. Heitschmidt and J. W. Stuth (eds.) Grazing Management: an Ecological Perspective. Timber Press, Portland, OR, USA.

Austin, J.E. 2002. Responses of dabbling ducks to wetland conditions in the prairie pothole region. Waterbirds 25: 465-473.

Austin, J.E., T.K. Buhl, G.R. Guntenspergen, W. Norling, and H.T. Sklebar. 2001. Duck populations as indicators of landscape condition in the prairie pothole region. Environmental Monitoring and Assessment 69: 29-47.

Babbitt, K.J., M.J. Baber, and T.L. Tarr. 2003. Patterns of larval amphibian distribution along a wetland hydroperiod gradient. Canadian Journal of Zoology 81:1539-1552.

A Review of indicators of wetland health and function in Alberta's prairie, aspen parkland and boreal 54 dry mixed wood regions 
Balcombe, C.K., J.T. Anderson, R.H. Fortney, and W.S. Kordek. 2005. Aquatic macroinvertebrate assemblages in mitigated and natural wetlands. Hydrobiologia 541: 175-188.

Barbour, M.T., J. Gerritsen, B.D. Snyder, and J.B. Stribling. 1997. Revision to rapid bioassessments protocols for use in streams and rivers: periphyton, benthic macroinvertebrates, and fish. U.S. Environmental Protection Agency, EPA 841-D-97002, Washington, D.C.

Batzer, D.P., B.J. Palik and R. Buech. 2004. Relationships between environmental characteristics and macroinvertebrate communities in seasonal woodland ponds of Minnesota. Journal of the North American Benthological Society. 23: 50-68.

Bayley, S.E., and R.L. Mewhort. 2004. Plant community structure and functional differences between marshes and fens in the southern boreal region of Alberta, Canada. Wetlands 24: 277-294.

Bayley, S.E., and C.M. Prather. 2003. Do wetland lakes exhibit alternative stable states? Submersed aquatic vegetation and chlorophyll in western boreal shallow lakes. Limnology and Oceanography 48: 2335-2345.

Bayley, S.E., I.F Creed, G.Z. Sass, and A.S. Wong. 2007. Frequent regime shifts in trophic states in shallow lakes on the Boreal Plain: Alternative "unstable" states? Limnology and Oceanography 52(4): 2002-2012.

Best, E.P.H., de Vries, D. and Reins, A.1984. The macrophytes in the Loosdrecht Lakes: story of their decline in the course of eutrophication. Verb. Int. Verein Limnology 22: 868-875.

Bethke, R.W. and T.D. Nudds. 1995. Effects of climate change and land use on duck abundance in Canadian prairie-parklands. Ecological Applications 5: 588-600.

Birch, G.F., C. Matthai, M.S. Fazeli, and J.Y. Suh. 2004. Efficiency of a constructed wetland in removing contaminants from stormwater. Wetlands 24: 459-466.

Bjorge, R. 1999. Waterfowl pair, brood and pond surveys of buffalo lake moraine. Alberta Environment. Red Deer Area.

Boone, M.D., and S.M. James. 2003. Interactions of an insecticide, herbicide and natural stressors in amphibian community mesocosms. Ecological Applications 13: 829-841.

Booth, D.B., and C.R. Jackson. 1997. Urbanization of aquatic systems: degradation thresholds, stormwater detection and the limits of mitigation. Journal of the American Water Resources Association 33: 1077-1090. 
Bowles, M.L., P.D. Kelsey and J.L McBride. 2005. Relationships among environmental factors, vegetation zones, and species richness in a north American calcareous prairie fen. Wetlands 25: 685-696.

Brown, S.C., and D.P. Batzer. 2001. Birds Plants and Macroinvertebrates as indicators of restoration success in New York marshes. In Rader, R.B., D.P. Batzer, and S.A. Wissinger (eds.) Bioassessment and management of North American freshwater wetlands. John Wiley and Sons, Inc., New York.

Bridgham, S.D., C.J. Richardson, E. Maltby, and S.P. Faulkner. 1991. Cellulose decay in natural and disturbed peatlands in North Carolina. Journal of Environmental Quality 20: 695701.

Bridgham, S. D., J. Pastor, J. A. Janssens, C. Chapin, and T. J. Malterer. 1996. Multiple limiting gradients in peatlands: A call for a new paradigm. Wetlands 16: 45-65.

Budelsky, R.A., and S.M. Galatowitsch. 2004. Establishment of Carex stricta Lam. Seedlings in experimental wetlands with the implications for restoration. Plant Ecology 175: 91-105.

Burton, T. M., D. G. Uzarski, J. P. Gathman, J. A. Genet, B. E. Keas, and C. A. Stricker. 1999. The development of an index of biotic integrity for Great Lakes coastal wetlands of Lake Huron. Wetlands 19:869-882.

Byrtus, G. 2000. Overview of 1998 pesticide sales in Alberta. Municipal Program Development Branch, Environmental Science Division, Environmental Service, Alberta Environment.

Caithamer, D.F., G.W. Smith, F.A. Johnson, J.B. Bortner, J.P. Bladen and R.D.Keywood. 1992. Trends in duck breeding populations 1955-92. Administrative Report 92/07-08. U.S. Fish and Wildlife Service, Washington, D.C.

Carpenter, S.R. and D.M. Lodge. 1986. Effects of submersed macrophytes on ecosystem processes. Aquatic Botany 26: 341-370.

Carpenter, S.R., N.F. Caraco, D.L. Correll, R.W. Horwath, A.N. Sharpley, and V.H. Smith. 1998. Nonpoint pollution of surface waters with phosphorus and nitrogen. Ecological Applications 8: 559-568.

Casey, R.J. 1995. Development of long-term biomonitoring in Elk Island National Park using benthic macroinvertebrates. Environmental Enhancement, Alberta Environment Centre.

Casey, R.J., C.A. Paszkowski, S.A. Kendall, N. Ambrose and B. Gingras. 1999. Effects of cattle grazing intensity on water chemistry, aquatic invertebrates, waterbirds, songbirds and amphibians of pothole ponds of the Aspen Parkland, Central Alberta. Institute for Wetland and Waterfowl Research. 
Chapin, C.T., S.D. Bridgham, and J. Pastor. 2004. pH and nutrient effects on above- ground net primary production in a Minnesota, USA bog and fen. Wetlands 24: 186-201.

Chow-Fraser, P. 1999. Seasonal, interannual, and spatial variability in the concentrations of the total suspended solids in a degraded coastal wetland of Lake Ontario. Journal of Great Lakes Research 25: 799-813.

City Of Calgary. 2004. Calgary Wetlands Conservation Plan. The City of Calgary Parks. Available at: http://www.calgary.ca/docgallery/bu/parks_operations/wetland_conservation_plan.pdf

Collins, S. L., A. K. Knapp, J. M. Briggs, J. M. Blair, and E. M. Steinauer. 1998. Modulation of diversity by grazing and mowing in native tallgrass prairie. Science 280: 745-747.

Conlon M.R. 2002. Predicting Fish Assemblages in Small, Boreal Lakes in Alberta Using Landscape and Local Factors. MSc Thesis, University of Alberta, Edmonton, AB.

Cooper, S.D., Walde, S.J., and Peckarsky, B.L. 1990. Prey exchange rates and the impact of predators on prey populations in streams. Ecology 71: 1503-1514.

Corstanje, R., and K.R. Reddy. 2004. Response of biogeochemical indicators to a drawdown and subsequent reflood. Journal of Environmental Quality 33: 2357-2366.

COSEWIC. 2003. Canadian Species at Risk, November 2002. Committee on the Status of Endangered Wildlife in Canada, Ottawa, ON.

Craft, C.B. and C.J. Richardson. 1993. Peat accretion and phosphorus accumulation along a eutrophication gradient in the northern everglades. Biogeochemistry 22: 133-156.

Craft, C.B., and C.J. Richardson. 1997. Relationships between soil nutrients and plant species composition in Everglades peatlands. Journal of Environmental Quality 26: 224-232.

Crosbie, B., and P. Chow-Fraser. 1999. Percentage land use in the watershed determines the water and sediment quality of 22 marshes in the Great Lakes basin. Canadian Journal of Fisheries and Aquatic Sciences 56: 1781-1791.

Crumpton, W. G. \& L. G. Goldsborough, 1998. Nitrogen transformation and fate in prairie wetlands. Great Plains Res. 8:57-72.

Danylchuk, A.J., and W.M. Tonn. 2003. Natural disturbances and fish: local and regional influences on winterkill of fathead minnows in boreal lakes. Transactions of the American Fisheries Society 132: 289-298.

Davis, C.B., and A.G. van der Valk. 1978. Litter decomposition in prairie glacial marshes. In: R.E. Good, D. F. Whigham, and R.L. Simpson (eds.) Freshwater Wetlands. Academic Press, NY. pp 99-130. 
Dechka, J.A., S.E. Franklin, M.D.Watmough, R.P. Bennett, and D.W. Ingstrup. 2002. Classification of wetland habitat and vegetation communities using multi-temporal Ikonos imagery in southern Saskatchewan. Canadian Journal of Remote Sensing 28: 679685 .

Denny, P.1994. Biodiversity and wetlands. Wetlands Ecology and Management 3: 55-61.

de Szalay, F.A. and V.H. Resh. 2000. Factors influencing macroinvertebrate colonization of seasonal wetlands: responses to emergent plant cover. Freshwater Biology 45: 295-308.

de Szalay F.A., Euliss N.H. \& Batzer D.P. 1999. Seasonal and semi permanent wetlands of California; invertebrate community ecology and responses to management methods. $\underline{\text { In: }}$ D.P. Batzer, R.B. Rader, and S.A.Wissinger (eds.) Invertebrates in Freshwater Wetlands of North America : Ecology and Management. John Wiley and Sons, New York, NY.

Detenbeck, N.E., C.M. Elonen, D.L. Taylor, L.E. Anderson, T.M. Jicka, and S.L. Batterman. 2003. Effects of hydrogeomorphic region, catchment storage and mature forest on baseflow and snowmelt stream water quality in second-order Lake Superior Basin tributaries. Freshwater Biology 48: 912-927.

Detenbeck, N.E., S.M. Galatowitsch, J. Atkinson, and H. Ball. 1999. Evaluating perturbations and developing restoration strategies for inland wetlands In the Great Lakes Basin. Wetlands 19: 789-820.

Devito, K.J., I.F. Creed, R.L. Rothwell, and E.E. Prepas. 2000. Landscape controls on phosphorus loading to boreal lakes: implications for the potential impacts of forest harvesting. Canadian Journal of Fisheries and Aquatic Sciences 57: 1977-1984.

Diaz, H. F. 1986. An analysis of twentieth century climate fluctuations in northern North America. Journal of Climatology and Applied Meteorology 25: 1625-1657.

Dieter, C.D. 1991. Water turbidity in tilled and untilled prairie wetlands. Journal of Freshwater Ecology 6: 185-189.

Dodson, S.I., and R.A. Lillie. 2001. Zooplankton communities of restored depressional wetlands in Wisconsin USA. Wetlands 21: 292-300.

Donald, D.B., J. Syrgiannis, F. Hunter and G. Weiss.1999. Agricultural pesticides threaten the ecological integrity of northern prairie wetlands. The Science of the Total Environment 231: 173-181.

Ducks Unlimited Canada. 2004. Natural Values: the importance of wetlands and upland conservation practices in watershed management: functions and values for water quality and quantity. DUC. 
Eaton, B.R., S. Eaves, C. Stevens, A. Puchiak, and C.A. Paszkowski. 2004. Deformity levels in wild populations of the Wood Frog (Rana sylvatica) in three ecozones of Western Canada. Journal of Herpetology 38: 283-287.

Englund, G. 1991. Effects of disturbance on stream moss and invertebrate community structure. Journal of the North American Benthological Society 10: 143-153.

Environment Canada. 2004. Water: An Ecosystem Perspective. Available at: http://www.ec.gc.ca/water/en/info/pubs/primer/e_prim05.htm

Epners, C. 2007. The importance of fish presence and community structure to waterfowl abundance in the boreal transition zone of Alberta. MSc thesis, University of Alberta.

Euliss, N.H., and D.M. Mushet. 1996. Water-level fluctuation in wetlands as a functionof landscape condition in the prairie pothole region. Wetlands 16: 587-593.

Euliss, N. H., Jr. and D. M. Mushet. 1999. Influence of agriculture on aquaticinvertebrate communities of temporary wetlands in the prairie pothole region of North Dakota, USA. Wetlands 19:578-583.

Fairbairn, S.E., and J.J. Dinsmore. 2001. Local and landscape-level influences on wetland bird communities of the prairie pothole region of Iowa, USA. Wetlands 21: 41-47.

Ferone, J.M., and K.J. Devito. 2004. Shallow groundwater-surface water interactions in pondpeatland complexes along a Boreal Plains topographic gradient. Journal of Hydrology 292: 75-95.

Findlay, C.S. and J. Houlahan. 1997. Anthropogenic correlates of species richness in southeastern Ontario wetlands. Conservation Biology 11:1000-1009.

Flinn, M.B., M.R.Whiles, S.R. Adams, and J.E. Garvey. 2005. Macroinvertebrate and zooplankton responses to emergent plant production in upper Mississippi River floodplain wetlands. Archiv Fur Hydrobiologie 162: 187-210.

Floder, S., and C.W. Burns. 2004. Phytoplankton diversity of shallow tidal lakes: Influence of periodic salinity changes on diversity and species number of a natural assemblage. Journal of Phycology 40: 54-61.

Foote, A.L. and C.L. Rice-Hornung. 2005. Odonates as biological indicators of grazing effects on Canadian prairie wetlands. Ecological Entomology 30: 273-283.

Forest, S. F. 2001. Peatland management and conservation in Boreal Alberta, Canada. M.Sc. Thesis. University of Alberta. 
Freeman, P.L., and M.S. Schorr. 2004. Influence of watershed urbanization on fine sediment and macroinvertebrate assemblage characteristics in Tennessee Ridge and Valley Streams. Journal of Freshwater Ecology 19: 353-362.

Galatowitsch, S.M., and A.G. van derValk. 1996. The vegetation of restored and natural prairie wetlands. Ecological Applications 6: 102-112.

Galatowitsch, S.M., D.C. Whited, J.R. Tester, and M. Power. 1998. Development of community metrics to evaluate recovery of Minnesota wetlands. Journal of Aquatic Ecosystem Stress and Recovery 6: 217-234.

Galatowitsch, S.M., D.C. Whited, R. Lehtinen, J. Husveth, and K. Schik. 2000. The vegetation of wet meadows in relation to their land-use. Environmental Monitoring and Assessment 60: 121-144.

Geleta, S., G.J. Sabbagh, J.F. Stone, R.L. Elliott, H.P. Mapp, D.J. Bernardo, and K.B. Watkins. 1994. Importance of soil and cropping systems in the development of regional water quality policies. Journal of Environmental Quality 23: 36-42.

Gleason, R. A. and N. H. Euliss, Jr. 1998. Sedimentation of prairie wetlands. Great Plains Research 8:97-112.

Gleason, R.A., N.H. Euliss, D.E. Hubbard, and W.G. Duffy. 2003. Effects of sediment load on emergence of aquatic invertebrates and plants from wetland soil egg and seed banks. Wetlands 23: 26-34.

Gleason, R.A., N.H. Euliss, Jr., D.E. Hubbard, and W.G. Duffy. 2004. Invertebrate egg banks of restored, natural, and drained wetlands in the prairie pothole region of the United States. Wetlands 24: 562-572.

Goldsborough, L. G. and W. G. Crumpton. 1998. Distribution and environmental fate of pesticides in prairie wetlands. Great Plains Research 8:73-95.

Goldsborough, L.G. and B. J. Hann. 1995. Enclosure affects trophic structure of a freshwater prairie wetland. UFS (Delta Marsh) Annual Report 30: 63-67.

Goldsborough, L.G., and G.G.C. Robinson. 1996. Patterns in wetlands. Pages 77-117. In R.J. Stevenson, M.L. Bothwell, and R.L. Lowe (eds.) Algal Ecology: Freshwater Benthic Ecosystems. Academic Press, NY.

Gorham, E. 1991. Northern peatlands - role in the carbon cycle and probable responses to climatic warming. Ecological Applications 1: 182-195.

Grant, S.C.H., and W.M. Tonn. 2002. Effects of nutrient enrichment on recruitment of age-0 fathead minnows (Pimephales promelas): potential impacts of environmental change on the Boreal Plains. Canadian Journal of Fisheries and Aquatic Sciences 59: 759-767.

A Review of indicators of wetland health and function in Alberta's prairie, aspen parkland and boreal 60 dry mixed wood regions 
Greenlee, G.M., P.D. Lund, D.R. Bennett, and D.E. Mikalson. 2000. Surface water quality studies in the Lethbridge northern and Bow River irrigation districts. Irrigation Branch, Alberta Agriculture, Food and rural Development, Lethbridge Alberta.

Gingras, B.A., and C.A. Paszkowski. 1999. Breeding patterns of Common Loons on lakes with three different fish assemblages in north-central Alberta. Canadian Journal of Zoology 77: 600-609.

Hall, D.L., M.R. Willig, D.L. Moorhead, R.W. Sites, E.B. Fish, and T.R. Mollhagen. 2004. Aquatic macroinvertebrate diversity of playa wetlands: the role of landscape and island biogeographic characteristics. Wetlands 24: 77-91.

Hamilton, I.M., J.L. Skilnick, H. Troughton, A.P. Russell, and G.L. Powell.1998. Status of the Canadian toad (Bufo hemiophrys) in Alberta. Wildlife Status Report No. 12. Alberta Environmental Protection, Wildlife Management Division, and the

Alberta Conservation Association, Edmonton, AB.

Hann, B.J., and L.G. Goldsborough. 1997. Responses of a prairie wetland to press and pulse additions of inorganic nitrogen and phosphorus: invertebrate community structure and interactions. Archiv Fur Hydrobiologie 140: 169-194.

Hann, B.J., C.J. Mundy, and L.G. Goldsborough. 2001. Snail-periphyton interactions in a prairie lacustrine wetland. Hydrobiologia 457: 167-175.

Hannon, S.J., C.A. Paszkowski, S. Boutin, J. DeGroot, S.E. Macdonald, M. Wheatley and R. Eaton. 2002. Abundance and species composition of amphibians, small mammals, and songbirds in riparian forest buffer strips of varying widths in the boreal mixedwood of Alberta. Canadian Journal of Forest Research 32: 1784-1800.

Hanson, M.A., K.D. Zimmer, M.G. Butler, B.A. Tangen, B.R. Herwig, and N.H. Euliss. 2005. Biotic interactions as determinants of ecosystem structure in prairie wetlands: An example using fish. Wetlands 25: 764-775.

Hart, E.A. and J.R. Lovvorn. 2005. Patterns of macroinvertebrate abundance in inland saline wetlands: a trophic analysis. Hydrobiologia 541: 45-54.

Helawell, J.M. 1986. Biological indicators of freshwater pollution and environmental management. Elsevier Applied Science Publishers, NY.

Hestbeck, J.B. 1995. Response of northern pintail breeding populations to drought, $1961-1962$. Journal of Wildlife Management 59: 9-15.

Higgins, K.F., and W.T. Barker.1982. Changes in vegetation structure in seeded nesting cover in the prairie pothole region. United States Department of the Interior, Fish and Wildlife Service. Special Scientific Report - Wildlife No. 242, Washington D.C. 
Higgins, M. J., and R.W. Merritt. 1999. Temporary woodland ponds in Michigan: Invertebrate seasonal patterns and trophic relationships. In: D. P. Batzer, R. D. Rader, and S. A. Wissinger (eds.) Invertebrates in freshwater wetlands of North America: ecology and management. John Wiley and Sons, New York. pp. 279-297.

Hobson, K.A., E.M. Bayne, and S.L. Van Wilgenburg. 2002. Large-scale conversion of forest to agriculture in the boreal plains of Saskatchewan. Conservation Biology 16: 1530-1541.

Hood, G.A. 2007. Impact of fire, climate change, and herbivory on the configuration of riparian vegetation and maintenance of beaver ponds in Elk Island National Park. PhD. Thesis. University of Alberta.

Horwath, W.R. and E.A. Paul. 1994. Microbial biomass, Ch. 36. In: Weaver R.W. et al. (eds) Methods of Soil Analysis Part 2 Microbiological and Biochemical Properties. Soil Science Society of America, Madison Wisconsin, USA. pp. 753-773.

Houlahan, J.E., and C.S. Findlay. 2003. The effects of adjacent land use on wetland amphibian species richness and community composition. Canadian Journal of Fisheries and Aquatic Sciences 60: 1078-1094.

Hunter, M.D., and P.W. Price. 1992. Playing chutes and ladders: heterogeneity and relative forces of bottom-up and top-down forces in natural communities. Ecology 73: 724- 732.

Jacks, G., and A.C. Norrstrom. 2004. Hydrochemistry and hydrology of forest riparian wetlands. Forest Ecology and Management 196: 187-197.

Jackson, L.J. 2003. Macrophyte-dominated and turbid states of shallow lakes: evidence from Alberta Lakes. Ecosystems 6: 213-223.

Jacques Whitford Inc. 2005. Scope of work for the initial assessment of aquatic ecosystem health in Alberta. Alberta Environment, Edmonton, AB.

Johnson, R.K. 1998. Spatiotemporal variability of temperate lake macroinvertebrate communities: detection of impact. Ecological Applications 8: 61-70.

Johnson, D.H, and J.W. Grier. 1988. Determinants of breeding distributions of ducks. Wildlife Monographs 100: 1-37.

Johnson, D.H., and T.L. Shaffer. 1987. Are mallards declining in North America? Wildlife Society Bulletin 15: 340-345.

Johnson, D. H., Sparling, D. W. and Cowardin, L. M.1987. A model of the productivity of the mallard duck. Ecological Modeling 38: 257-275.

A Review of indicators of wetland health and function in Alberta's prairie, aspen parkland and boreal 62 dry mixed wood regions 
Kalff, J. 2002. Limnology: inland water ecosystems. Prentice Hall, Upper Saddle River, New Jersey.

Kantrud, H.A. 1986. Effects of vegetation manipulation on breeding waterfowl in prairie wetlands - a literature review. United States Department of Interior, Fish and Wildlife Service, Technical Report 3. Northern Prairie Wildlife Research Centre, Jamestown, North Dakota.

Kantrud, H. A. and W. E. Newton. 1996. A test of vegetation-related indicators of wetland quality in the prairie pothole region. Journal of Aquatic Ecosystem Health 5:177-191.

Kantrud, H.A., J.B. Millar, and A.G. van der Valk.1989. Vegetation of wetlands of the prairie pothole region. In: A.G. van der Valk (ed.) Northern Prairie Wetlands. Iowa State University Press, Ames. Pp. 132-187.

Karr, J.R. 1993. Defining and assessing ecological integrity: beyond water quality Environmental Toxicology and Chemistry 12:1521-1531.

Karr, J.R. and Chu, E.W. 1997. Biological monitoring and assessment using multimetric indexes effectively. EPA 235-R97-001. University of Washington, Seattle, Washington.

Karr, J. R. and E. W. Chu. 1999. Restoring Life in Running Waters: Better Biological Monitoring. Island Press, Washington, DC, USA.

Karr, J. R., K. D. Fausch, P. L. Angermeier, P. R. Yant, and I. J. Schlosser. 1986. Assessing biological integrity in running waters: a method and its rationale. Illinois Natural History Survey, Champaign, IL, USA.

Kashian, D.R., and T.M. Burton. 2000. A comparison of macroinvertebrates of two Great Lakes coastal wetlands: Testing potential metrics for an index of ecological integrity. Journal of Great Lakes Research 26: 460-481.

Keddy, P.A. 2000. Wetland ecology: principles and conservation. Cambridge University Press.

Kettles, I.M., and C. Tarnocai. 1999. Development of a model for estimating the sensitivity of Canadian peatlands to climate warming. Geographie Physique et Quaternaire 53: 323338.

Kim, J.G. 2003. Response of sediment chemistry and accumulation rates to recent environmental changes in the Clear Lake watershed, California USA. Wetlands 23: 95-103.

King, R.S., and C.J. Richardson. 2002. Evaluating subsampling approaches and macroinvertebrate taxonomic resolution for wetland bioassessment. Journal of the North American Benthological Society 21: 150-171. 
King, R. S., K. T. Nunnery, and C. J. Richardson. 2000. Macroinvertebrate assemblage response to highway crossings in forested wetlands: implications for biological assessment. Wetlands Ecology and Management 8:243-256.

Klapproth, J.C. 2000. Understanding the science behind riparian forest buffers: effects on water quality. Virginia Cooperative Extension, Virginia State University. Publication Number 420-151.

Klarer, D.M. and D.F. Millie. 1992. Aquatic macrophytes and algae at Old Woman Creek Estuary and other Great Lakes coastal wetlands. Journal of Great Lakes Research 18: 622-633.

Koch, M.S., and K.R. Reddy. 1992. Distribution of soil and plant nutrients along a trophic gradient in the Florida Everglades. Soil Science Society of America Journal 56: 14921499.

Koopowitz, H., A.D. Thornhill, and M. Andersen. 1994. A general stochastic model for the prediction of biodiversity losses based on habitat conversion. Conservation Biology 8: 425-438.

Kostecke, R.M., L.M. Smith, and H.M. Hands. 2005. Macroinvertebrate response to cattail management at Cheyenne Bottoms, Kansas, USA. Wetlands 25: 758-763.

Kotak, B.G., A.K.Y. Lam, E.E. Prepas, and S.E. Hrudey. 2000. Role of chemical and physical variables in regulating microcystin-LR concentration in phytoplankton of eutrophic lakes. Canadian Journal of Fisheries and Aquatic Sciences 57: 1584-1593.

LaBaugh, J.W. 1995. Relation of algal biovolume to chlorophyll-a in selected lakes and wetlands in the north central United States. Canadian Journal of Fisheries and Aquatic Sciences 52: 416-424.

Lee, J., B.Chen, H.E. Allen, C.P. Huang, D.L. Sparks, and P. Sanders. 1992. Trace metal soil quality criteria to protect ground water. Water Science and Technology 26: 2327-2329.

Lee, P., D. Aksenov, L. Laestadius, R. Nogueron, and W. Smith. 2003. Canada's large intact forest landscapes. Global Forest Watch, Edmonton, AB, Canada.

Lillie, R.A. and J.O. Evrard. 1994. Influence of macroinvertebrates and macrophytes on waterfowl utilization of wetlands in the prairie pothole region of northwestern Wisconsin. Hydrobiologia 280: 235-246.

Locky, D.A., S.E. Bayley, and D.H Vitt. 2005. The vegetational ecology of black spruce swamps, fens, and bogs in southern boreal Manitoba, Canada. Wetlands 25: 564-582.

Locky, D.A. and S.E. Bayley. 2006. Plant diversity, composition, and rarity in the southern boreal peatlands of Manitoba, Canada. Canadian Journal of Botany 84: 940-955.

A Review of indicators of wetland health and function in Alberta's prairie, aspen parkland and boreal 64 dry mixed wood regions 
Lopez, R.D., and M.S. Fennessy. 2002. Testing the floristic quality assessment index as an indicator of wetland condition. Ecological Applications 12: 487-497.

Lougheed, V.L., and P. Chow-Fraser. 1998. Factors that regulate the zooplankton community structure of a turbid, hypereutrophic Great Lakes wetland. Canadian Journal of Fisheries and Aquatic Sciences 55: 150-161.

Lougheed, V.L., and P. Chow-Fraser. 2002. Development and use of a zooplankton index of wetland quality in the Laurentian Great Lakes basin. Ecological Applications 12: 474486.

Lougheed, V.L., B. Crosbie, and P. Chow-Fraser. 2001. Primary determinants of macrophyte community structure in 62 marshes across the Great Lakes basin: latitude, land use, and water quality effects. Canadian Journal of Fisheries and Aquatic Sciences 58: 1603-1612.

Lowe, R.L. and Y. Pan.1996. Benthic algal communities as biological monitors. In: R.J. Stevenson, M.L Bothwell and R.L. Lowe (eds.) Algal ecology: freshwater benthic ecosystems. Academic Press, NY. pp. 705-739.

MacKenzie, R.A., J.L. Kaster and J.V. Klump. 2004. The ecological patterns of benthic invertebrates in a Great Lakes coastal wetland. Journal of Great Lakes Research 30: 5869.

Macrae, M.L., T.E. Redding, I.F. Creed, W.R. Bell, and K.J. Devito. 2004. Soil, surface water and ground water phosphorus relationships in a partially harvested Boreal Plain aspen catchment. Forest Ecology and Management 206: 315-329.

Maher, W., G.E. Batley, and I. Lawrence. 1999. Assessing the health of sediment ecosystems: use of chemical measurements. Freshwater Biology 41: 361-372.

Matthews, E., and I. Fung, 1987. Methane emission from natural wetlands: Global distribution, area, and environmental characteristics of sources, Global Biogeochemical Cycles 1: 6186.

Matthews, J.W., P.A. Tessene, S.M. Wiesbrook and B.W. Zercher. 2005. Effect of area and isolation on species richness and indices of floristic quality in Illinois, USA wetlands. Wetlands 25: 607-615.

Mayer, P.M., and S.M. Galatowitsch. 1999. Diatom communities as ecological indicators of recovery in restored prairie wetlands. Wetlands 19: 765-774.

Mayer, P.M., R.O. Megard, and S.M. Galatowitsch. 2004. Plankton respiration and biomass as functional indicators of recovery in restored prairie wetlands. Ecological Indicators 4: 245-253. 
McCormick, P.V. and R.J. Stevenson. 1998. Periphyton as a tool for ecological assessment and management in the Florida Everglades. Journal of Phycology 34: 726-733.

McDougal, R.L., L.G. Goldsborough, and B.J. Hann. 1997. Responses of a prairie wetland to press and pulse additions of inorganic nitrogen and phosphorus: production by planktonic and benthic algae. Archiv Fur Hydrobiologie 140: 145-167.

McGowan, C.P., T.R. Simons, W. Golder, and J. Cordes. 2005. A comparison of American Oystercatcher reproductive success on barrier beach and river island habitats in coastal North Carolina. Waterbirds 28: 150-155.

McNair, S.A., and P. Chow-Fraser. 2003. Change in biomass of benthic and planktonic algae along a disturbance gradient for 24 Great Lakes coastal wetlands. Canadian Journal of Fisheries and Aquatic Sciences 60: 676-689.

Melaas, M.L., K.D. Zimmer, M.G. Butler, and M.A. Hanson. 2001. Effects of rotenone on aquatic invertebrate communities in prairie wetlands. Hydrobiologia 459: 177-186.

Mensing, D.M., S.M. Galatowitsch, and J.R. Tester. 1998. Anthropogenic effects on the biodiversity of riparian wetlands of a northern temperate landscape. Journal of Environmental Management 53: 349-377.

Mewhort, R.L. 2000. Nitrogen dynamics and ecological characteristics in marshes and fens in boreal Alberta, Canada. MSc thesis, University of Alberta, Edmonton, Alberta, Canada

Mickle, A.M. 1993. Pollution filtration by plants in wetland-littoral zones. Proceedings of the Academy of Natural Sciences of Philadelphia 144: 282-290.

Miller, M.R., and D.C. Duncan. 1999. The northern pintail in North America: status andconservation needs of a struggling population. Wildlife Society Bulletin 27: 788-800.

Miller, M.R., J.P. Fleskes, D.L Orthmeyer, and D.S. Gilmer. 1992. Survival and other observations of adult female northern pintails molting in California. Journal of Field Ornithology 63: 138-144.

Mitchell, P. and E. Prepas.1990. Atlas of Alberta Lakes. University of Alberta Press, Edmonton.

Mitsch, W. J. and J. G. Gosselink. 2000. Wetlands. John Wiley and Sons, Inc., New York, NY, USA.

Moore, P.D. 2002. The future of cool temperate bogs. Environmental Conservation 29: 3-20.

Moore, T.R., N.T. Roulet, and J.M. Waddington. 1998. Uncertainty in predicting the effect of climatic change on the carbon cycling of Canadian peatlands. Climatic Change 40(2): 229-245. 
Morrison, D. 2002. The western boreal forest. Birdscapes: News from International Habitat Conservation Partnerships Winter 2002:14-15.

Moss, B., J. Stansfield, K. Irvine, M. Perrow, and G. Phillips. 1996. Progressive restoration of a shallow lake: a 12-year experiment in isolation, sediment removal and biomanipulation. Journal of Applied Ecology 33: 71-86.

Murkin, H.R., A.G. van der Valk, and C.B. Davis. 1989. Decomposition of 4 dominant macrophytes in the Delta Marsh, Manitoba. Wildlife Society Bulletin 17: 215-221.

Murkin, H.R., M.P. Stainton, J.A. Boughen, J.B. Pollard and R.D. Titman. 1991. Nutrient status of wetlands in the interlake region of Manitoba, Canada. Wetlands 11: 105-122.

Murkin, E.J., H.R. Murkin and R.D. Titman. 1992. Nektonic invertebrate abundance and distribution at the emergent vegetation-open water interface in the Delta Marsh, Manitoba, Canada. Wetlands 12: 45-52.

Mushet, D.M., N.H. Euliss, and T.L. Shaffer. 2002. Floristic quality assessment of one natural and three restored wetland complexes in North Dakota, USA. Wetlands 22: 126-138.

Naiman, R.J., J.J. Magnuson, D.M. McKnight, J.A. Stanford, and J.A. Karr. 1995. Freshwater ecosystems and their management - a national initiative. Science 270: 584-585.

National Wetlands Working Group. 1997. The Canadian Wetland Classification System, second edition. Wetlands Researeh Centre, Waterloo, ON, Canada.

National Wetlands Working Group. 1988. Wetlands of Canada. Sustainable Development Branch, Environment Canada, Ottawa and Polyscience Publications Inc. Montreal, PQ, Canada.

Naugle, D.E., K.F. Higgins, and S.M Nusser. 1999. Effects of woody vegetation on prairie wetland birds. Canadian Field Naturalist 113: 487-492.

Naugle, D.E., R.R. Johnson, M.E. Estey, and K.F. Higgins. 2001. A landscape approach to conserving wetland bird habitat in the prairie pothole region of eastern South Dakota. Wetlands 21: 1-17.

Neely, R.K. and J. Baker. 1989. Nitrogen and phosphorus dynamics and the fate of agricultural runoff. In: A.G. van der Valk (ed.) Northern Prairie Wetlands, Iowa State University, Ames.

Niemi, G., D. Wardrop, R. Brooks, S. Anderson, V. Brady, H. Paerl, C. Rakocinski, M. Brouwer, B. Levinson, and M. McDonald. 2004. Rationale for a new generation of indicators for coastal waters. Environmental Health Perspectives 112: 979-986. 
Norlin, J.I., S.E. Bayley, and L.C.M. Ross. 2005. Submerged macrophytes, zooplankton and the predominance of low- over high-chlorophyll states in western boreal, shallow-water wetlands. Freshwater Biology 50: 868-881.

Nudds, T.D. and R.G. Clark. 1993. Landscape ecology, adaptive resource management, and the North American Waterfowl Management Plan. In: G.L. Holroyd, H.L. Dickson, M. Regnier, and H.C. Smith (eds.) Proceedings of the Third Prairie Conference and Endangered Species Workshop. Provincial Museum of Alberta Natural History Occasional Paper 19. pp. 180-190.

Ontkean, G.R., D.S. Chanasyk, S. Riemersma, D.R. Bennett, and J.M. Brunen. 2003. Enhanced prairie wetland effects on surface water quality in Crowfoot Creek, Alberta. Water Quality Research Journal of Canada 38: 335-359.

Ozimek, T., E. Pieczynska, and A. Hankiewicz. 1991. Effects of filamentous algae on submerged macrophyte growth - a laboratory experiment. Aquatic Botany 41: 309-315.

Packer, J.G., and C.E. Bradley. 1984. Rare vascular plants of Alberta. Natural History Occasional Paper No. 5, Provincial Museum of Alberta, Edmonton, AB.

Paillisson, J.M., S. Reeber, and L. Marion. 2002. Bird assemblages as bio-indicators of water regime management and hunting disturbance in natural wet grasslands. Biological Conservation 106: 115-127.

Pan, Y., R.J. Stevenson, P. Vaithiyanathan, J. Slate and C.J. Richardson. 2000. Changes in algal assemblages along observed and experimental phosphorus gradients in a subtropical wetland, USA. Freshwater Biology 44: 339-353.

Panno, S.V., V.A. Nuzzo, K. Cartwright, B.R. Hensel, and I.G. Krapac. 1999. Impact of urban development on the chemical composition of ground water in a fen-wetland complex. Wetlands 19: 236-245.

Paszkowski, C.A., and W.M. Tonn. 2000. Community concordance between the fish and aquatic birds of lakes in northern Alberta, Canada: the relative importance of environmental and biotic factors. Freshwater Biology 43: 421-437.

Paszkowski, C.A., B.A. Gingras, K. Wilcox, P.H. Klatt and W.M. Tonn. 2004. Trophic relations of the Red-necked Grebe on lakes in the Western Boreal Forest: A stable-isotope analysis. Condor 106: 638-651.

Paul, M.J., and J.L. Meyer. 2001. Streams in the urban landscape. Annual Review of Ecology and Systematics 30: 333-365.

Pettigrove, V., and A. Hoffmann. 2005. A field-based microcosm method to assess the effects of polluted urban stream sediments on aquatic macroinvertebrates. Environmental Toxicology and Chemistry 24: 170-180. 
Pickett, S.T.A. and P.S. White.1985. The ecology of natural disturbance and patch dynamics. Academic Press, NY.

Plafkin, J.L., M.T. Barbour, K.D. Porter, S.K.Gross, and R.M. Hughes.1989. Rapid bioassessment protocols for use in streams and rivers: benthic macroinvertebrates and fish. EPA/440/4-89-001. Office of Water, US Environmental protection Agency, Washington, DC.

Podruzny, K.M., J.H. Devries, L.M. Armstrong, and J.J. Rotella. 2002. Long-term response of northern pintails to changes in wetlands and agriculture in the Canadian Prairie Pothole Region. Journal of Wildlife Management 66: 993-1010.

Poiani, K. A., and W. C. Johnson. 2003. Simulation of hydrology and vegetation dynamics of prairie wetlands in the Cottonwood Lake Area. In: T.C. Winter, (ed.), Hydrological, Chemical, and Biological Characteristics of a Prairie Pothole Wetland Complex under Highly Variable Climate Conditions - The Cottonwood Lake Area, East-central North Dakota. USGS Professional Paper 1675, Denver, USA. Pp. 95-109.

Prepas, E.E., D. Planas, J.J. Gibson, D.H. Vitt, T.D. Prowse, W.P. Dismore, L.A. Halsey, P.M. McEachern, S. Paquet, G.J. Scrimgeour, W.M. Tonn, C.A. Paszkowski, and K. Wolfstein. 2001. Landscape variables influencing nutrients and phytoplankton communities in Boreal Plain lakes of northern Alberta: a comparison of wetland- and upland-dominated catchments. Canadian Journal of Fisheries and Aquatic Sciences 58: 1286-1299.

Prescott, C.E. 1995. Does nitrogen availability control rates of litter decomposition in forests? Plant and Soil: $168-169: 83-88$.

Qualls, R.G., and C.J. Richardson. 2002. Factors controlling concentration, export, and decomposition of dissolved organic nutrients in the Everglades of Florida. Biogeochemistry 62: 197-229.

Rader, R. B., D. P. Batzer, and S. A. Wissinger (eds.). 2001. Bioassessment and Management of North American Freshwater Wetlands. John Wiley \& Sons. Inc., New York, NY, USA.

Rast, W. and G.F. Lee. 1983. Nutrient loading estimates for lakes. Journal of Environmental Engineering 109: 502-517.

Rejmankova, E., and J. Komarkova. 2005. Response of cyanobacterial mats to nutrient and salinity changes. Aquatic Botany 83: 87-107.

Robinson, G. G. C., S.E. Gurney, and L.G. Goldsborough. 1997. The primary productivity of benthic and planktonic algae in a prairie wetland under controlled water-level regimes. Wetlands 17: $182-194$. 
Rose, C., and W.G. Crumpton. 1996. Effects of emergent macrophytes on dissolved oxygen dynamics in a prairie pothole wetland. Wetlands 16: 495-502.

Rosenberg, D.M. and V.H. Resh. 1993. Introduction to freshwater biomonitoring and benthic macroinvertebrates. In: D.M. Rosenberg and V.H. Resh (eds.) Freshwater biomonitoring and benthic macroinvertebrates. Chapman and Hall, NY. pp. 1-9.

Rutchey, K., and L. Vilchek. 1999. Air photo interpretation and satellite imagery analysis techniques for mapping cattail coverage in a northern Everglades impoundment. Photogrammetric Engineering and Remote Sensing 65: 185-191.

Sandilands, K.A., B.J. Hann, and L.G. Goldsborough. 2000. The impact of nutrients and submersed macrophytes on invertebrates in a prairie wetland, Delta Marsh, Manitoba. Archiv Fur Hydrobiologie 148: 441-459.

Savard, J.P.L., W.S. Boyd, and G.E.J. Smith. 1994. Waterfowl wetland relationships in the aspen parkland of British Columbia - comparison of analytical methods. Hydrobiologia 280: $309-325$.

Schallenberg, M., and C.W. Burns. 2004. Effects of sediment resuspension on phytoplankton production: teasing apart the influences of light, nutrients and algal entrainment. Freshwater Biology 49: 143-159.

Schindler, D.W. 1987. Detecting ecosystem responses to anthropogenic stress. Canadian Journal of Fisheries and Aquatic Sciences 44: 6-25.

Schlesinger, W.H. 1991. Biogeochemistry An analysis of global change. Academic Press, Toronto.

Semlitsch, R.D., J.W. Gibbons, and T.D. Tuberville. 1995. Timing of reproduction and metamorphosis in the Carolina gopher frog (Rana capito capito) in South Carolina. Journal of Herpetology 29: 612-614.

Shay, J.M., P.M.J. de Geus, and M.R.M. Kapinga. 1999. Changes in shoreline vegetation over a 50 -year period in the Delta Marsh, Manitoba in response to water levels. Wetlands 19: 413-425.

Soranno, P.A., S.L. Hubler, S.R. Carpenter, and R.C. Lathrop. 1996. Phosphorus loads to surface waters: A simple model to account for spatial pattern of land use. Ecological Applications 6: 865-878.

Spieles, D.J., and W.J. Mitsch. 2000. Macroinvertebrate community structure in high- and lownutrient constructed wetlands. Wetlands 20: 716-729. 
Stapanian, M.A., T.A. Waite, G. Krzys, J.J. Mack, and M. Micaccion. 2004. Rapid assessment indicator of wetland integrity as an unintended predictor of avian diversity.

Hydrobiologia 520: 119-126.

Steinman, A., K. Havens, and L. Hornung. 2003. The managed recession of Lake Okeechobee, Florida: Integrating science and natural resource management. Conservation Ecology 6: 17.

Stevenson, R.J., P.V. McCormick, and R. Frydenborg. 2001. Methods for evaluating wetland condition: using algae to assess environmental conditions in wetlands. U.S. EPA, Office of Water, Washington, DC.

Stewart, R.E., and H.A. Kantrud. 1971. Classification of natural ponds and lakes in the glaciated prairie region. U.S. Fish and Wildlife Service, Resource publication $92.57 \mathrm{pp}$.

Strong, W.L. and K.R. Leggat. 1981. Ecozones of Alberta. Alberta Energy and Natural Resources, Edmonton, AB.

Strong, W.L. and K.R. Leggat. 1992. Ecoregions of Alberta. Alberta Energy and Natural resources. Edmonton. AB.

Swanson, G.A., T.C. Winter, V.A. Adomaitis, and J.W. LaBaugh. 1988. Chemical characteristics of prairie lakes in south-central North Dakota - their potential for influencing use by fish and wildlife. U.S. Fish and Wildlife Service Technical Report 18.

Szumigalski, A.R., and S.E. Bayley. 1996. Net above-ground primary production along a bogrich fen gradient in central Alberta, Canada. Wetlands 16: 467-476.

Takats, L. and C. Priestley. 2002. Alberta amphibian call surveys: a pilot year. Final report. Alberta Sustainable Resource Development, Fish and Wildlife Division, Alberta Species at Risk, Edmonton. Rep. No. 53.

Tangen, B.A., M.G. Butler, and J.E. Michael. 2003. Weak correspondence between macroinvertebrate assemblages and land use in Prairie Pothole Region wetlands, USA. Wetlands 23: 104-115.

Tarnocai, C. 1980. Summer temperatures of cryosolic soils in the north-central Keewatin, NWT. Canadian Journal of Soil Science 60: 311-327.

Tate, R.L. 1995. Soil Microbiology, 2nd edition. John Wiley and Sons, Inc. New York. Taylor, B.R., and J. Helwig. 1995. Submergent macrophytes in a cooling pond in Alberta, Canada. Aquatic Botany 51: 243-257.

Thormann, M. N. and S. E. Bayley. 1997. Decomposition along a moderate-rich fen- marsh peatland gradient in boreal Alberta, Canada. Wetlands 17:123-137.

A Review of indicators of wetland health and function in Alberta's prairie, aspen parkland and boreal 71 dry mixed wood regions 
Thormann, M.N., A.R. Szumigalski, and S.E. Bayley. 1999. Aboveground peat and carbon accumulation potentials along a bog-fen-marsh wetland gradient in southern boreal Alberta, Canada. Wetlands 19: 305-317.

Tonn, W.M., C.A. Paszkowski, G.J. Scrimgeour, P.K.M. Aku, M. Lange, E.E. Prepas, and K. Wescott. 2003. Effects of forest harvesting and fire on fish assemblages in Boreal Plains lakes: A reference condition approach. Transactions of the American Fisheries Society 132: $514-523$.

Turner, B.C., Hochbaum, G.S., and Caswell, F.D. 1987. Agricultural impacts on wetland habitats on the Canadian prairies, 1981-85. Transactions of the North American Wildlife Natural Resources Conference 52: 206-216.

U.S. EPA. 2002a. Methods for evaluating wetland condition: biological assessment methods for birds. Office of Water, U.S. Environmental Protection Agency, Washington, DC. EPA822-R-02-023.

U.S. EPA. 2002b. Methods for evaluating wetland condition: developing an invertebrate index of biological integrity for wetlands. Office of Water, U.S. Environmental Protection Agency, Washington, DC. EPA-822-R-02-019.

U.S. EPA. 2002c. Methods for evaluating wetland condition: developing metrics and indexes of biological integrity. Office of Water, U.S. Environmental Protection Agency, Washington, DC. EPA-822-R-02-016.

U.S. EPA. 2002d. Methods for evaluating wetland condition: introduction to wetland biological assessment. Office of Water, U.S. Environmental Protection Agency, Washington, DC. EPA-822-R-02-014.

U.S. EPA. 2002e. Methods for evaluating wetland condition: using algae to assess environmental conditions in wetlands. Office of Water, U.S. Environmental Protection Agency, Washington, DC. EPA-822-R-02-021.

U.S. EPA. 2002f. Methods for evaluating wetland condition: vegetation-based indicators of wetland nutrient enrichment. Office of Water, U.S. Environmental Protection Agency, Washington, DC. EPA-822-R-02-024.

van der Valk, A.G. 2005. Water-level fluctuations in North American prairie wetlands. Hydrobiologia 539: 171-188.

van der Valk, A. and C. Davis. 1978. The role of seed banks in the vegetation dynamics of prairie glacial marshes. Ecology 59: 322-335.

VanRees-Siewert, K. L., and J. L. Dinsmore 1996. Influence of wetland age on bird use of restored wetlands in Iowa. Wetlands 16: 577-582.

A Review of indicators of wetland health and function in Alberta's prairie, aspen parkland and boreal 72 dry mixed wood regions 
Vitousek, P.M. 1994. Beyond global warming - ecology and global change. Ecology 75: 1861 1876.

Vitousek P.M., C.M. DAntonio, L.L. Loope, and R. Westbrook. 1996. Biological invasions as global environmental change. American Scientist 84: 468-478.

Vos, C.C., and A.H.P. Stumpel. 1996. Comparison of habitat-isolation parameters in relation to fragmented distribution patterns in the tree frog (Hyla arborea). Landscape Ecology 11: 203-214.

Wake, D.B. 1991. Declining amphibian populations. Science 253: 860.

Walker, B.H., and R.T. Coupland. 1970. Herbaceous wetland vegetation in aspen grove and grassland regions of Saskatchewan. Canadian Journal of Botany 48: 1861. Walters, D. and D. Shrubsole. 2003. Agricultural drainage and wetland management in Ontario. Journal of Environmental Management 69: 369-379.

Wauchope, R.D., R.F. Davis, H.R. Sumner, C.C. Dowler, J.E. Hook, L.C. Chandler, C.C. Truman, J.G. Davis, A.W. Johnson, and G.J. Gascho. 1994. The mechanics of pesticide runoff. Abstracts of papers of the American chemical Society 207: 52-AGRO Part 1.

Westbrook, C.J. 2000. Nitrogen dynamics in upland peatland boreal shield soils before and after clearcutting. MSc. Thesis, University of Alberta, Edmonton, AB.

Westbrook, C.J., and K.J. Devito. 2004. Gross nitrogen transformations in soils from uncut and cut boreal upland and peatland coniferous forest stands. Biogeochemistry 68: 33-49.

Whiles, M.R., and B.S. Goldowitz. 2005. Macroinvertebrate communities in Central Platte River wetlands: Patterns across a hydrologic gradient. Wetlands 25: 462-472.

White, D.S. 1988. Persistent toxic substances and zoobenthos in the Great Lakes. In: Evans, M.S. (ed) Great Lakes ecosystems health: Effects of toxic substances. John Wiley \& Sons Inc., New York.

White, J.S., S.E. Bayley and P.J. Curtis. 2000. Sediment storage of phosphorus in a northern prairie wetland receiving municipal and agro-industrial wastewater. Ecological Engineering 14: 127-138.

White, J.S., and S.E. Bayley. 2001. Nutrient retention in a northern prairie marsh (Frank Lake, Alberta) receiving municipal and agro-industrial wastewater. Water Air and Soil Pollution 126: 63-81.

Whitehouse, H.E., and S.E. Bayley. 2005. Vegetation patterns and biodiversity of peatland plant communities surrounding mid-boreal wetland ponds in Alberta, Canada. Canadian Journal of Botany 83: 621-637. 
Wilcox, D.A., J.E. Meeker, P.L. Hudson, B.J. Armitage, M.G. Black and D.G. Uzarski. 2002. Hydrologic variability and the application of index of biotic integrity metrics to wetlands: A Great Lakes evaluation. Wetlands 22: 588-615.

Wilkins, K.A., M.C. Otto, and G.W. Smith. 2002. Trends in duck breeding populations, 19552002. United States Fish and Wildlife Service, Laurel, Maryland.

Winter, T.C. 1988. Conceptual framework for assessment of cumulative impacts on the hydrology of non-tidal wetlands. Environmental Management 12: 605-620.

Winter, T.C. 1989. Hydrologic studies of wetlands in the northern prairie. In: A.G. van der Valk (ed) Northern Prairie Wetlands. Iowa State University Press, Ames, IA, USA. pp. 16-54.

World Resources Institute. 2000. Canada's forests at a crossroads: an assessment in the year 2000. Global forest watch Canada.

Wray, H.E. 2005. Nitrogen dynamics in marshes and fens in boreal Alberta. MSc Thesis. University of Alberta, Edmonton, AB.

Wright, H.A., and A.W. Bailey. 1982. Fire ecology, United States and southern Canada. John Wiley and Sons, Inc. New York.

Zheng, L., R.J. Stevenson, and C. Craft. 2004. Changes in benthic algal attributes during salt marsh restoration. Wetlands 24: 309-323.

Zimmer, K.D., M.A. Hanson, M.G. Butler, and W.G. Duffy. 2001. Size distribution of aquatic invertebrates in two prairie wetlands, with and without fish, with implications for community production. Freshwater Biology 46: 1373-1386.

Zimmer, K.D., M.A. Hanson, and M.G. Butler. 2000. Factors influencing invertebrate communities in prairie wetlands: a multivariate approach. Canadian Journal of Fisheries and Aquatic Sciences 57: 76-85.

Zimmer, K.D., M.A. Hanson, and M.G. Butler. 2003. Interspecies relationships, community structure, and factors influencing abundance of submerged macrophytes in prairie wetlands. Wetlands 23: 717-728.

Zoltai, S.C. and D.H. Vitt 1995. Canadian wetlands: Environmental gradients and classification. Vegetation 118:131-137.

Zrum, L., and B.J. Hann. 2002. Invertebrates associated with submersed macrophytes in a prairie wetland: Effects of organophosphorus insecticide and inorganic nutrients. Archiv Fur Hydrobiologie 154: 413-445.

A Review of indicators of wetland health and function in Alberta's prairie, aspen parkland and boreal 74 dry mixed wood regions 
Zrum, L., B.J. Hann, L.G. Goldsborough, and G.A. Stern. 2000. Effects of organophosphorus insecticide and inorganic nutrients on the planktonic microinvertebrates and algae in a prairie wetland. Archiv Fur Hydrobiologie 147: 373-399. 


\begin{tabular}{|c|c|c|c|c|}
\hline Indicator & $\begin{array}{c}\text { Prairie } \\
\text { (Canada and } \\
\text { USA) }\end{array}$ & $\begin{array}{c}\text { Aspen } \\
\text { parkland } \\
\text { (Alberta) }\end{array}$ & $\begin{array}{l}\text { Dry boreal } \\
\text { mixed wood } \\
(\text { Alberta })\end{array}$ & $\begin{array}{c}\text { Other regions } \\
\text { (that have papers } \\
\text { of interest) }\end{array}$ \\
\hline \multicolumn{5}{|c|}{ Biological Indicators } \\
\hline Algae & $\begin{array}{l}\text { Mayer \& } \\
\text { Galatowitsch } \\
\text { 1999, 2001, } \\
\text { LaBaugh 1994, } \\
\text { Zrum et al. 2000, } \\
\text { McDougal et al. } \\
\text { 1997, Sandilands } \\
\text { et al. 2000, Hann } \\
\text { and Goldsborough } \\
\text { 1997, Murkin et al. } \\
\text { 1991, Murkin et al. } \\
\text { 1989, } \\
\text { Goldsborough and } \\
\text { Hann 1995 }\end{array}$ & $\begin{array}{l}\text { Robarts et al. } \\
1995, \text { Taylor and } \\
\text { Helwig } 1995\end{array}$ & $\begin{array}{l}\text { Prepas et al. } 2000 \text {, } \\
\text { Bayley \& Prather } \\
\text { 2003, Grant and } \\
\text { Tonn } 2002\end{array}$ & $\begin{array}{l}\text { Wu and Mitsch 1998, } \\
\text { US EPA 2002e, } \\
\text { McCormick and } \\
\text { Stevenson 1998, } \\
\text { Stevenson et al. 2001, } \\
\text { Lowe and Pan 1996, } \\
\text { Schallenberg and } \\
\text { Burns 2004, Floder } \\
\text { and Burns 2004, Pan et } \\
\text { al. 2000, Best et al. } \\
\text { 1984, Ozimek et al. } \\
\text { 1991, McNair and } \\
\text { Chow-Fraser 2003, } \\
\text { Rejmankova and } \\
\text { Komarkova 2005, } \\
\text { Zheng et al. 2004, } \\
\text { McNair and Chow- } \\
\text { Fraser 2003, Schindler } \\
\text { 1987, Mayer and } \\
\text { Galatowitsch 1999, } \\
\text { Zheng et al. 2004 }\end{array}$ \\
\hline $\begin{array}{l}\text { Zooplankton, } \\
\text { Invertebrates }\end{array}$ & $\begin{array}{l}\text { Mayer et al. 2004, } \\
\text { Plum 2005, } \\
\text { Tangen et al. 2003, } \\
\text { Zrum and Hann } \\
\text { 2002, Melaas et al. } \\
2001\end{array}$ & Casey et al. 1999 & $\begin{array}{l}\text { Norlin et al. 2005, } \\
\text { Mitchell and Prepas } \\
\text { 1990, Prepas et al. } \\
2001\end{array}$ & $\begin{array}{l}\text { Rosenberg and Resh } \\
\text { 1993, Karr and Chu } \\
\text { 1997, Burton et al. } \\
\text { 1999, King et al. 2000, } \\
\text { Rader et al. 2001, } \\
\text { Lougheed and chow- } \\
\text { Fraser 1998, Barbour } \\
\text { et al. 1997, MacKenzie } \\
\text { et al. 2004 }\end{array}$ \\
\hline $\begin{array}{l}\text { Vascular } \\
\text { plants and } \\
\text { bryophytes }\end{array}$ & $\begin{array}{l}\text { Budelsky \& } \\
\text { Galatowitsch } \\
\text { 1999, Seabloom \& } \\
\text { van der Valk 2003, } \\
\text { Zimmer et al. } \\
\text { 2003, Dechka et al. } \\
\text { 2002, Zrum and } \\
\text { Hann 2002, } \\
\text { Sandilands et al. } \\
\text { 2000, Zimmer et } \\
\text { al. 2001, Shay et } \\
\text { al. 1999, Rose and } \\
\text { Crumpton 1996, } \\
\text { Bowles et al. 2005, } \\
\text { Kantrud 1986, } \\
\text { Mushet et al. 2002, }\end{array}$ & $\begin{array}{l}\text { Schultz \& } \\
\text { Thormann 2005, } \\
\text { Nicholson 1995, } \\
\text { Taylor and Helwig } \\
\text { 1995, Casey et al. } \\
1999\end{array}$ & $\begin{array}{l}\text { Locky et al. } 2005 \text {, } \\
\text { Whitehouse \& } \\
\text { Bayley 2005, } \\
\text { Bayley and Prather } \\
2003 \text {, Bayley et al. } \\
2007\end{array}$ & $\begin{array}{l}\text { Rejmankova 2005, } \\
\text { Mushet et al. 2002, } \\
\text { Middleton 2003, } \\
\text { Cohen et al. 2005, } \\
\text { Spieles 2005, Belland } \\
\text { \&Vitt 1995, Matthews } \\
\text { et al. 2005, Daoust and } \\
\text { Childers 1999, } \\
\text { Templer et al. 1998, } \\
\text { Lougheed and Chow- } \\
\text { Fraser 2001, US EPA } \\
\text { 2002f, Davis and van } \\
\text { der Valk 1983, Craft } \\
\text { and Richardson 1997, } \\
\text { Pano et al. 1999, } \\
\text { Lougheed et al. 2001, }\end{array}$ \\
\hline
\end{tabular}

A Review of indicators of wetland health and function in Alberta's prairie, aspen parkland and boreal 76 dry mixed wood regions 


\begin{tabular}{|c|c|c|c|c|}
\hline & $\begin{array}{l}\text { Lillie and Evrard } \\
\text { 1994, Zimmer et } \\
\text { al. 2003, } \\
\text { Galatowitsch et al. } \\
\text { 1998, Gleason and } \\
\text { Euliss 1998, } \\
\text { Gleason et al. } \\
\text { 2003, Murkin et al. } \\
1992\end{array}$ & & & $\begin{array}{l}\text { Best et al. 1984, } \\
\text { Ozimek et al. 1991, } \\
\text { McNair and Chow- } \\
\text { Fraser 2003, Matthews } \\
\text { et al. 2005, Lopez and } \\
\text { Fennessy 2002, } \\
\text { Adamus et al. } 2001\end{array}$ \\
\hline $\begin{array}{l}\text { Macro- } \\
\text { invertebrates }\end{array}$ & $\begin{array}{l}\text { Tangen et al. 2003, } \\
\text { Jenkins et al. 2003, } \\
\text { Gleason et al. } \\
\text { 2004, Foote \& } \\
\text { Rice Hornung } \\
\text { 2005, Hornung \& } \\
\text { Rice 2003, Murkin } \\
\text { et al. 1992, Zrum } \\
\text { et al. 2000, Hann } \\
\text { and Goldsborough } \\
\text { 1997, Neckles et } \\
\text { al. 1990, Lillie and } \\
\text { Evrard 1994, } \\
\text { Zimmer et al. } \\
\text { 2000, Murkin et al. } \\
\text { 1992, Whiles and } \\
\text { Goldowitz 2005, } \\
\text { Batzer et al. 2004, } \\
\text { Euliss 1999, } \\
\text { Gleason et al. } \\
\text { 2003, Dodson and } \\
\text { Lillie 2001 }\end{array}$ & Casey 1995 & & $\begin{array}{l}\text { Steinman et al. 2003, } \\
\text { Flinn et al. 2005, } \\
\text { Jeffries 1994, Bataille } \\
\text { and Baldassarre 1993, } \\
\text { Magee and } \\
\text { Fredrickson 1993, US } \\
\text { EPA 2002b, Pettigrove } \\
\text { and Hoffman 2005, } \\
\text { Hart and Lovvorn } \\
\text { 2005, Kashian and } \\
\text { Burton 2000, Flinn et } \\
\text { al. 2005, Adamus et al. } \\
\text { 2001, King and } \\
\text { Richardson 2002, } \\
\text { McCormick et al. } \\
\text { 2004,Hall et al. 2004, } \\
\text { Freeman and Schorr } \\
\text { 2004, Spieles and } \\
\text { Mitsch 2000, De } \\
\text { Szalay and Resh 2000, } \\
\text { Balcombe et al. 2005 }\end{array}$ \\
\hline $\begin{array}{l}\text { Fish and } \\
\text { Amphibians }\end{array}$ & $\begin{array}{l}\text { Relyea 2005, } \\
\text { Zimmer et al. } \\
\text { 2002, Hanson et al. } \\
\text { 2005, Zimmer et } \\
\text { al. 2001, Swanson } \\
\text { et al. 1988, Euliss } \\
\text { et al. 1999, } \\
\text { Zimmer et al. } \\
\text { 2000, Tangen et al. } \\
\text { 2003, Semlitsch et } \\
\text { al. 1995 }\end{array}$ & $\begin{array}{l}\text { Casey et al. 1999, } \\
\text { Turner et al. 1987, } \\
\text { Hamilton et al. } \\
\text { 1998, Takats and } \\
\text { Priestley 2002, } \\
\text { Eaton et al. 2004, } \\
\text { Hannon et al. 2002 }\end{array}$ & $\begin{array}{l}\text { Conlon 2002, Tonn } \\
\text { et al. 2003, } \\
\text { Danylchuk and } \\
\text { Tonn } 2003\end{array}$ & $\begin{array}{l}\text { Pollet \& Bendell- } \\
\text { Young, 2000, } \\
\text { Houlahan and Findlay } \\
\text { 2003, Mallory et al. } \\
\text { 1994, Findlay et al. } \\
\text { 2002, Babbitt et al. } \\
\text { 2003, Mensing et al. } \\
\text { 1998, Boone and } \\
\text { James } 2003\end{array}$ \\
\hline Birds & $\begin{array}{l}\text { Bethke \& Nudds } \\
\text { 1995, Naugle et al. } \\
\text { 2001, Naugle et al. } \\
\text { 1999, Podruzny et } \\
\text { al. 2002, Fairbairn } \\
\text { and Dinsmore } \\
\text { 2001, Lille and } \\
\text { Evrard 1994, } \\
\text { Higgins and } \\
\text { Barker 1982, } \\
\text { Kantrud 1986, } \\
\text { Paillisson et al. } \\
\text { 2002, Caithamer et } \\
\text { al. 1992, Nudds }\end{array}$ & $\begin{array}{l}\text { Mack et al. 2003, } \\
\text { Miller 2000, } \\
\text { Eskowitch et al. } \\
\text { 1998, Bjorge 1999, } \\
\text { Casey et al. 1999, } \\
\text { Johnson and Grier } \\
\text { 1988, Hestbeck } \\
\text { 1995, Bethke and } \\
\text { Nudds 1995, } \\
\text { Caithamer et al. } \\
\text { 1992, Nudds and } \\
\text { Clark 1993, } \\
\text { Johnson and } \\
\text { Shaffer } 1987\end{array}$ & $\begin{array}{l}\text { Hobson et al. 2000, } \\
\text { Johnson and Grier } \\
\text { 1988, Hestbeck } \\
\text { 1995, Paszkowski } \\
\text { et al. 2004, } \\
\text { Morrison 2002, } \\
\text { Bethke and Nudds } \\
\text { 1995, Paszkowski } \\
\text { and Tonn } 2000\end{array}$ & $\begin{array}{l}\text { Kingsford 1999, } \\
\text { Savard et al. 1994, } \\
\text { Fairbairn and Dismore } \\
\text { 2001, Naugle et al. } \\
\text { 1999, US EPA 2002a, } \\
\text { Koopowitz et al. 1994, } \\
\text { Vos and 85 } \\
\text { Stumpel 1995 }\end{array}$ \\
\hline
\end{tabular}

A Review of indicators of wetland health and function in Alberta's prairie, aspen parkland and boreal 


\begin{tabular}{|c|c|c|c|c|}
\hline & $\begin{array}{l}\text { and Clark 1993, } \\
\text { Johnson and } \\
\text { Shaffer 1987, } \\
\text { Lillie and Evrard } \\
\text { 1994, Austin et al. } \\
\text { 2001, Stapanian et } \\
\text { al. 2004, Batt et al. } \\
\text { 1989, Austin } 2002\end{array}$ & & & \\
\hline \multicolumn{5}{|c|}{ Chemical Indicators- water and sediment } \\
\hline $\begin{array}{l}\text { TP, other } \\
\text { water } \\
\text { chemistry }\end{array}$ & $\begin{array}{l}\text { White et al. 2000, } \\
\text { Amon et al. 2002, } \\
\text { Ontkean et al. } \\
\text { 2003, Waiser } \\
\text { 2001, Zrum and } \\
\text { Hann 2002, } \\
\text { Sandilands et al. } \\
\text { 2000, Hann and } \\
\text { Goldsborough } \\
\text { 1997, McDougal et } \\
\text { al. 1997, Zimmer } \\
\text { et al. 2001, Rose } \\
\text { and Crumpton } \\
\text { 1996, Casey et al. } \\
\text { 1999, White and } \\
\text { Bayley 2001, } \\
\text { Prepas et al. 2001, } \\
\text { Shay et al. 1999, } \\
\text { Detenbeck et al. } \\
\text { 2003, Foote and } \\
\text { Rice-Hornung } \\
\text { 2005, Dieter 1991, } \\
\text { Jackson 2003, } \\
\text { Goldsborough and } \\
\text { Robinson 1996, } \\
\text { Zrum et al. 2000 }\end{array}$ & $\begin{array}{l}\text { Nicholson 1995, } \\
\text { Casey et al. 1999, } \\
\text { Anderson et al. } \\
\text { 2002, Savard et al. } \\
1994 \text { (British } \\
\text { Columbia study) }\end{array}$ & $\begin{array}{l}\text { Prepas et al. 2000, } \\
\text { Macrae et al. 2004, } \\
\text { Devito et al. 2000, } \\
\text { Norlin et al. 2005, } \\
\text { Bayley and Prather } \\
\text { 2003, Mitchell and } \\
\text { Prepas 1990, } \\
\text { Bayley et al. } 2007\end{array}$ & $\begin{array}{l}\text { Declerck et al. 2005, } \\
\text { Lee \& Bukaveckas } \\
\text { 2002, Dorioz \& Ferhi } \\
\text { 1994, Dodds 2003, } \\
\text { Brenner et al. 1998, } \\
\text { Panno et al. 1999, } \\
\text { Greiner and Hershner } \\
\text { 1998, Moss et al. 1996, } \\
\text { Pan et al. 2000, } \\
\text { Kashian and Burton } \\
\text { 2000, Crosbie and } \\
\text { Chow-Fraser } 1999\end{array}$ \\
\hline $\begin{array}{l}\text { Sediment } \\
\text { chemistry } \\
\text { (metals, } \\
\text { nutrients) }\end{array}$ & $\begin{array}{l}\text { Mewhort 2000, } \\
\text { Richardson et al. } \\
1994\end{array}$ & & $\begin{array}{l}\text { Turetsky et al. } \\
\text { 2000, Thormann et } \\
\text { al. 1999, Wray } \\
\text { 2005, Devito et al. } \\
\text { 2000, Westbrook } \\
2000\end{array}$ & $\begin{array}{l}\text { Aldous et al. 2005, } \\
\text { Crosbie \& Chow-Fraer } \\
\text { 1999, Chapin et al. } \\
\text { 2004, Devito \& Hill } \\
\text { 1999, Kim 2003, } \\
\text { Templer et al. 1998, } \\
\text { Helawell 1986, White } \\
\text { 1988, Craft and } \\
\text { Richardson 1993, } \\
\text { Qualls and Richardson } \\
\text { 2002, Corstanje and } \\
\text { Reddy 2004, Lee et al. } \\
\text { 1992, Maher et al. } \\
\text { 1999, Freeman and } \\
\text { Schorr 2004 }\end{array}$ \\
\hline \multicolumn{5}{|c|}{ Physical Indicators } \\
\hline
\end{tabular}

A Review of indicators of wetland health and function in Alberta's prairie, aspen parkland and borea 


\begin{tabular}{|l|l|l|l|l|}
\hline $\begin{array}{l}\text { \% agriculture } \\
\text { in watershed, } \\
\text { hydrology, etc. }\end{array}$ & $\begin{array}{l}\text { Galatowitsch and } \\
\text { van der Valk 1996, } \\
\text { Detenbeck et al. } \\
\text { 2002, Naugle et al. } \\
\text { 1999, Podruzny et } \\
\text { al. 2002, } \\
\text { Fairbairn and } \\
\text { Dinsmore 2001, } \\
\text { Shay et al. 1999, } \\
\text { Casey et al. 1999, } \\
\text { Anderson et al. } \\
\text { Bowles et al. 2005, } \\
\text { Swanson et al. } \\
\text { 1988, Kantrud } \\
\text { 1986, Euliss and } \\
\text { Mushet 1996, van } \\
\text { der Valk 2005, } \\
\text { McGowan et al. } \\
\text { 2005, Detenbeck et } \\
\text { al. 2003 }\end{array}$ & & $\begin{array}{l}\text { Pevito et al. 2005, } \\
\text { Devito et al. 2000, } \\
\text { Prepas et al. 2001 }\end{array}$ & $\begin{array}{l}\text { Dodson et al. 2005, } \\
\text { Gergel et al. 1999, } \\
\text { Corstanje \& Reddy } \\
\text { 2004, Richardson } \\
\text { 1994, Walters \& } \\
\text { Shrubsole 2003, } \\
\text { Detenbeck et al. 1999, } \\
\text { Freeman and Schorr } \\
\text { 2004, Crosbie and } \\
\text { Chow-Fraser 1999, } \\
\text { Klapproth 2000, Rast } \\
\text { and Lee 1983, } \\
\text { Mensing et al. 1998, } \\
\text { Cooper et al. 1987 }\end{array}$ \\
& & & \\
\hline
\end{tabular}




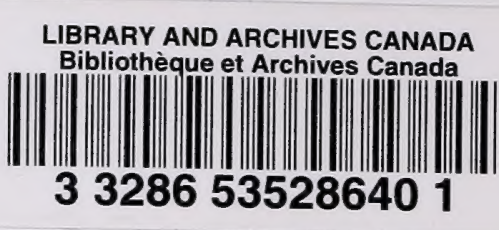

